National Mapping Program

Technical Instructions

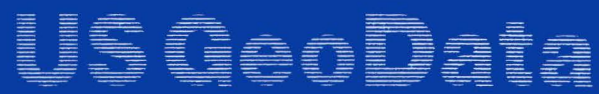

\title{
Digital Line Graphs from 1:100,000-Scale Maps
}

Data Users Guide 2 


\section{DATA USERS GUIDES}

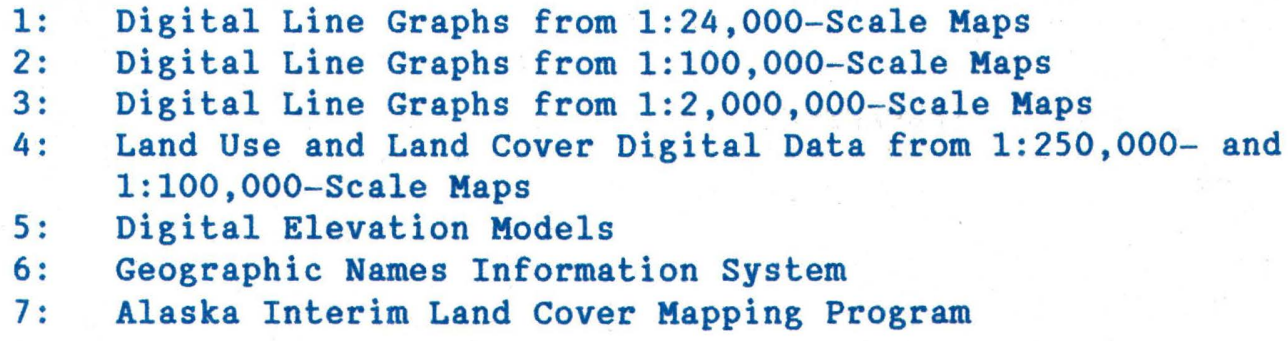

Data Users Guides generally replace the Geological Survey Circular 895 .

Questions regarding availability and ordering of US GeoData (all types of digital cartographic and geographic data produced and distributed by the U.S. Geological Survey) should be addressed to:

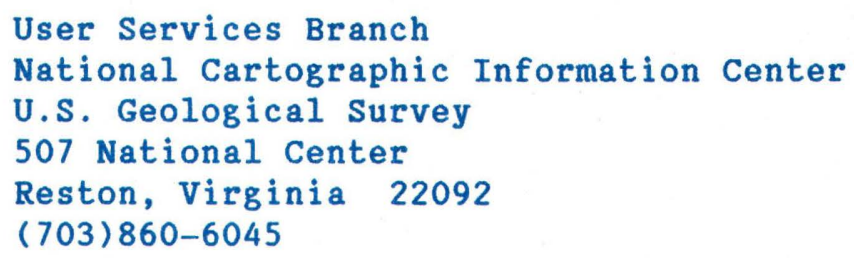


UNLIELD STATES

DEPARTMENT OF THE INTERIOR

U.S. GEOLOGICAL SURVEY

DIGITAL LINE GRAPHS FROM 1:100,000-SCALE MAPS

Data Users Guide 2

Reston, Virginia

1989 
First printing, 1985

Second printing (revised), 1989 


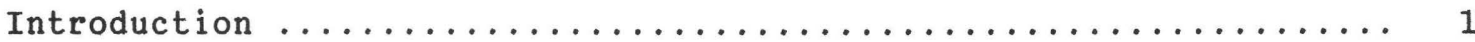

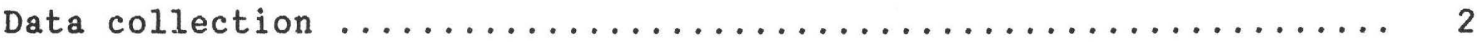

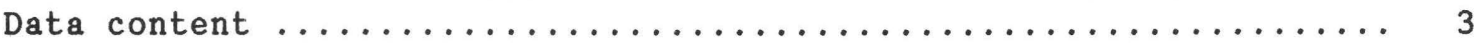

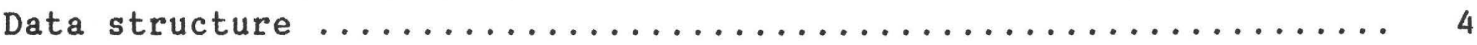

Levels of structuring ........................ 4

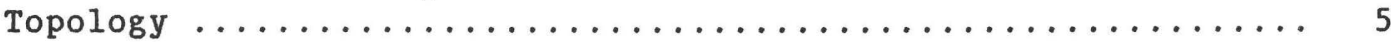

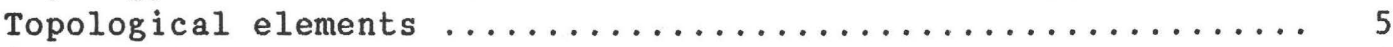

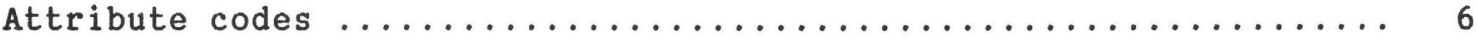

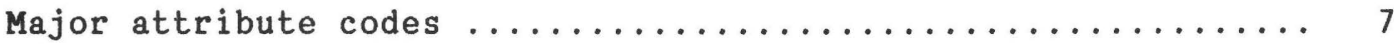

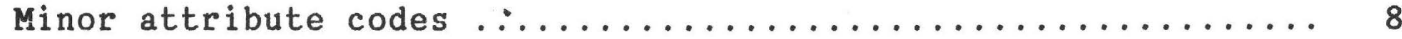

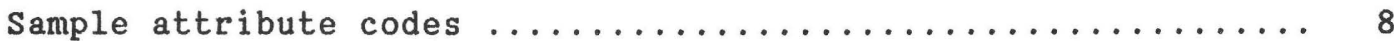

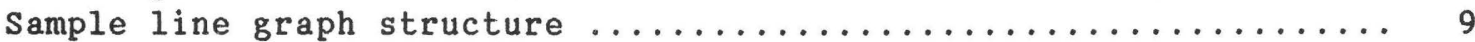

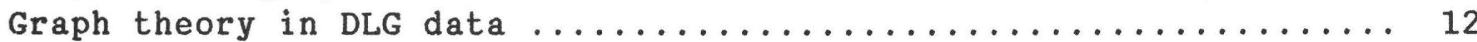

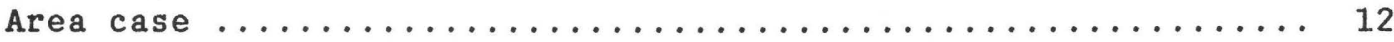

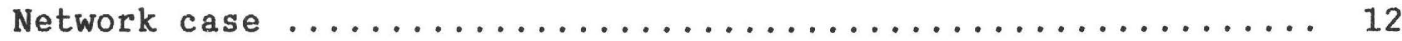

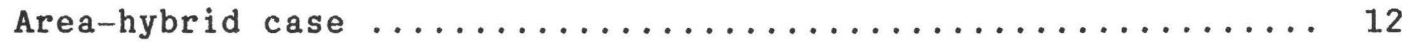

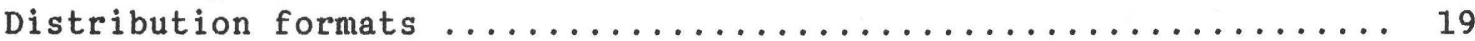

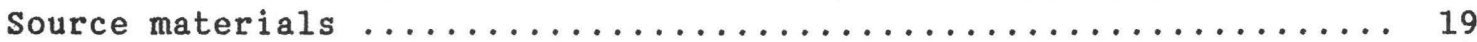

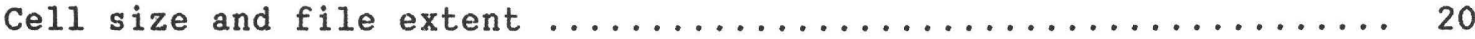

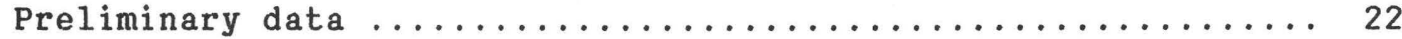

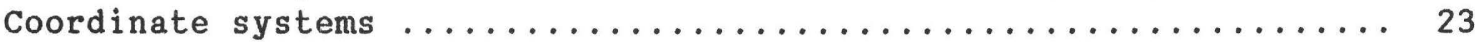

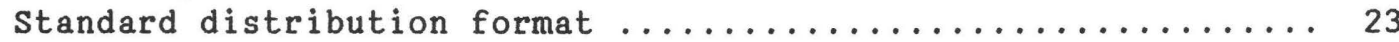

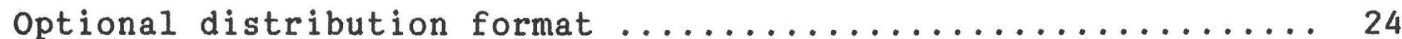

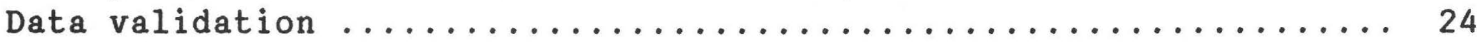

Appendix A. Standard DLG distribution format (record contents) ... 28

B. Optional DLG distribution format (record contents) ... 42

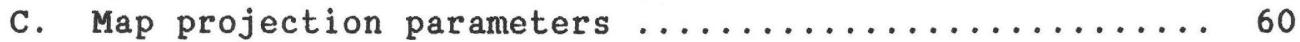

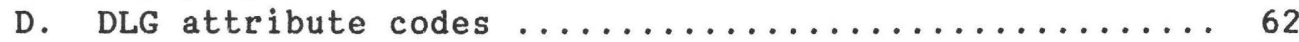

E. Coordinate conversion .......................... 79

F. Sample DLG data file (standard distribution

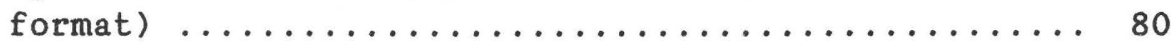

G. Sample DLG data file (optional distribution

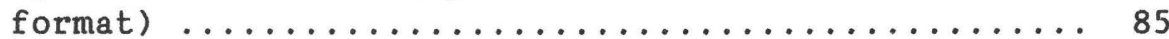

\section{ILLUSTRATIONS}

Page

Figure 1. Map elements showing roads, railroads, buildings, streams, and lake and forest areas .............66 6

2. Sample line graph ............................ 10

3. Window from the Cartersville, Ga., 1:100,000-scale

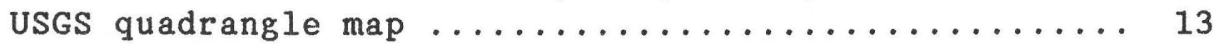


Figure 4. Plot from line graph of hydrography, Cartersville,

Ga., 7.5-minute section of quadrangle ........... 14

5. Sectioning scheme for DLG data of a $1: 100,000-$ scale

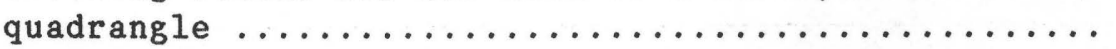

\section{TABLES}

Page

Table 1. Major codes used for DLG base categories ........... 7

2. Digital description of example DLG-3 ............. 11

3. Selected sample of standard format DLG-3 records

of Cartersville, Ga., 7.5-minute section of

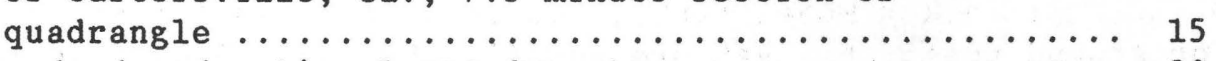

4. Standard and optional DLG format .............. 20 


\section{INTRODUCTION}

The National Cartographic Information Center (NCIC) distributes digital cartographic/geographic data files produced by the U.S. Geological Survey (USGS) as part of the National Mapping Program. Digital cartographic data files may be grouped into four basic types. The first of these, called a Digital Line Graph (DLG), is line map information in digital form. These data files include information on planimetric base categories, such as transportation, hydrography, and boundaries. The second form, called a Digital Elevation Model (DEM), consists of a sampled array of elevations for ground positions that are usually, but not always, at regularly spaced intervals. The third type is Land Use and Land Cover digital data, which provides information on nine major classes of land use such as urban, agricultural, or forest as well as associated map data such as political units and Federal land ownership. The fourth type, the Geographic Names Information system, provides primary information for known places, features, and areas in the United States identified by a proper name.

The digital cartographic data files from selected quadrangles currently available from NCIC include the following:

- Digital Line Graphs (DLG's)

$-1: 2,000,000-$ scale maps

--7.5- and 15-minute topographic quadrangle series

$--1: 100,000-$ scale quadrangle series

- Digital Elevation Models (DEM's)

$-7.5-$ minute quadrangle coverage

- -1.0-degree quadrangle coverage

- Land Use and Land Cover digital data

--1:250,000- and 1:100,000-scale land use and land cover and associated maps

$--1: 250,000-s c a l e$ Alaska Interim Land Cover Maps

- Geographic names

This document describes the Digital Line Graphs (DLG's) prepared from the 1:100,000-scale materials associated with the USGS Topographic Map Series. The series will eventually provide complete national coverage.

Any use of trade names and trademarks in this publication is for identification purposes only and does not constitute endorsement by the U.S. Geological Survey. 
The digital data are useful for the production of cartographic products, such as base maps, and the data are structured to support the analytical functions of geographic information systems. A typical use of base category digital cartographic data is to combine them with other geographically referenced data, enabling various automated spatial analyses to be conducted.

\section{DATA COLLECTION}

The following is a general overview of DLG data collection methods currently in use at the USGS. Individual Mapping Centers may vary the details of data collection, but the basic method and resultant DLG-3 files remain standard.

The USGS collects DLG data files using manual, semiautomatic, and automatic digitizing systems.

The manual digitizing method is accomplished primarily on Altek and Intergraph digitizing systems. Stable-base manuscripts of the relevant data categories are prepared from the original map separates. The operator initiates digitizing by fixing the manuscript to the digitizing table, and collecting registration points for the corners of the quad. Features and their corresponding attributes are digitized as lines, nodes, or areas. Both systems are capable of collecting the topological elements and their associated codes concurrently; in addition, the DLG processing software, PROSYS, is able to automatically place area pointings for areas which carry no attribute codes. The Altek digitizing systems currently in use by the USGS are basically "blind" systems. In order to view the captured data the operator must generate plots or utilize a separate graphics display terminal. The Intergraph systems at the USGS allow for the visual display of the digitizing in progress, interactive editing, and for access to commonly used attribute codes. When all positional and attribute coding is complete, the digitized data file is processed through PROSYS software, which builds the topology and identifies structural errors. On the Altek systems, coding and positional accuracy are verified using plots. The Intergraph system allows for visual confirmation of most codes, but plots are used for accuracy checks and for quality control in more complex areas. After the file has been corrected and reprocessed through PROSYS, it is entered into the National Digital Cartographic Data Base (NDCDB) as a DLG-3 file.

The semiautomatic line-following method of collecting data is accomplished on Laser-Scan systems. This is an interactive line-following digitizing and editing system. Graphic data are captured in vector format and the line strings interactively coded. The primary application of the LaserScan equipment at the USGS is to collect hypsography data. The Lasertrak digitizer uses a film negative that is a photographic reduction of the original source material. The reduction factor is dependent on the latitude of the quadrangle, the density of the data, and photographic line reduction limitations. Prior to each digitizing session, the operator performs calibration and registration procedures to ensure that digitizing accuracy is maintained. The reduced $\mathrm{film}$ negative is projected onto a large format display screen. The operator selects and codes the feature to be digitized, monitors the progress of the Lasertrak as the feature is 
automatically collected in vector format, and intervenes when an error occurs or when automatic line following is interrupted due to graphic ambiguities. The resulting vector file is processed to correct distortions and to detect errors, and plots are produced to facilitate quality control and editing. The Laser-Scan interactive Edit System allows for correction of digitizing errors, paneling of adjacent sections, and for manual collection and coding of categories of data which do not lend themselves to efficient line following. When editing is complete, the data are converted from Laser-Scan's Internal Feature Format into PROSYS input format and processed through PROSYS to build topology and identify structural errors. After the data file has been edited and reprocessed to correct errors, the DLG-3 file is entered into the NDCDB.

The automatic method of collecting data is accomplished using scitex raster scanning and editing systems. Graphic data are captured in raster format from composites of selected map features, then edited, and reformatted into vector data. In preparation for scanning, a stable-base composite of the map separates is prepared representing the data category to be collected. Prior to scanning, the manuscript is annotated in a prescan editing process to identify features or locations which will require inspection by the scitex operator. The scanned raster data file is manipulated interactively and in batch mode on the scitex Response color edit station. The first editing operation (postscan edit) is a general cleanup. The interactive editing is facilitated by automatic search routines which present the operator with the problem areas identified in the prescan edit. The linework is then skeletonized (thinned to a centerline of one-pixel width). A one-pixel gap is made in the linework at the locations of attribute change annotated during the prescan edit. These breaks in the linework mark the positions for node placement during structuring. Linear features symbolized by dots or dashes are changed to a continuous line, and point features, such as wells and rocks, are changed to single points through interactive edit and batch procedures. When line editing is complete, the raster files are vectorized. Complete or partial feature coding is accomplished using the manual and semiautomatic coding capabilities of the scitex edit stations. The files are then processed through PROSYS to build topology and to identify structural errors. Files which were only partially coded on the scitex are sent in DLG format to Intergraph stations for coding completion. Quality control plots are generated to check positional and coding accuracy; the corrected files are then reprocessed through PROSYS and entered into the NDCDB as DLG-3 files.

\section{DATA CONTENT}

The DLG data files derived from the 1:100,000-scale maps contain selected base categories of cartographic data in digital form; these data categories do not necessarily correspond to the traditional feature separates associated with the maps. The following categories are included in current 1:100,000 DLG files:

Hydrography -- This category of data describes combined hydrography consisting of all flowing water, standing water, and wetlands. 
- Transportation -- This category of data includes major transportation systems collected in three separate subcategories labeled: (1) roads and trails, (2) railroads, and (3) pipelines, transmission lines, and miscellaneous transportation.

- Hypsography -- This category of data consists of information on topographic relief (primarily contour data), and supplementary spot elevations.

- Boundaries -- This category of data consists of (1) political boundaries that identify states, counties, cities, and other municipalities, and (2) administrative boundaries that identify areas such as National and state forests. Political and administrative boundaries are always collected as a single data set.

Public Land Survey System (PLSS) -- This category of data describes the rectangular system of land surveys that is administered by the U.S. Bureau of Land Management. PLSS data are only collected for areas falling solely, or in part, within the states that were formed from the public domain. The PLSS subdivides the public domain and represents property boundaries or references to property boundaries. These DLG data are not intended to be official or authoritative. They are presented as cartographic reference information. The only legal basis for determining land boundaries remains the original survey.

The hypsography, boundary, and PLSS categories were authorized for production in late 1987. Currently there is very little data available in these categories.

The remaining categories: manmade features, survey control, vegetative surface cover, and nonvegetative features are projected to enter the production phase in 1990.

DATA STRUCTURE

\section{Levels of Structuring}

The term Digital. Line Graph (DLG) is used by the USGS to describe a digital map data set in vector form. Originally, three levels of DLG data (DLG-1, DLG-2, and DLG-3) were envisioned; these levels were differentiated by their positional accuracy, level of attribute coding, and relational spatial information. It was found, however, that the widest user community would by served by producing DLG-3 data, which have the full range of attribute codes and are fully topologically structured. These two properties are required by users whose work includes both graphic and analytic applications. Therefore, all DLG data in the National Digital Cartographic Data Base are level 3. 


\section{Topology}

Current data collection from 1:100,000-scale maps is exclusively directed toward producing fully topologically structured level 3 DLG data referred to as DLG-3. The DLG-3 concept is based on graph theory in which a twodimensional diagram is expressed as a set of nodes (topologically significant points), lines, and areas in a manner that explicitly expresses logical relationships. Applied to a map, this concept is used to encode the digital data with the spatial relationships between map elements which are obvious when the map is examined visually. The spatial relationships include such concepts as adjacency and connectivity between features on the map. The abstraction of the map data according to the rules of graph theory preserves the spatial relationships inherent in the map graphic and creates a logical and consistent data file structure for computer processing. A digital file of cartographic or geographic data that maintains the spatial relationships inherent in the map is called a topologically structured data file. A topologically structured data file can support simple graphic applications, such as plotting streams and roads for base maps, as well as more advanced applications, such as computations and analyses involving areas and lines and their spatial relationships.

\section{Topological Elements}

A DLG-3 file is composed of three separate, but related, elements: nodes, lines, and area identifiers. Nodes define the location of the endpoints of every line, and a single node may mark the start or end of one or more lines. Thus, nodes occur at intersections of linear features and other places on linear features where the feature is subdivided into separate line segments.

A line is an ordered set of points that describes the position and shape of a linear feature on the map. Each line starts at a node and ends at a node, and has an area to the left of its direction of travel, and has an area to the right of its direction of travel. The direction of travel is arbitrarily determined at the time of data capture. Lines connect to each other at nodes, and a line does not cross itself or any other line. A line may describe the boundary between two areal map features, such as counties, or may define a map feature by itself, such as a road. A special line, called a degenerate line, is used to define features symbolized as independent points on a map. A degenerate line starts and ends at the same node, has two identical coordinate pairs, has zero length, and has the same area to the left and right of the direction of travel; that is, it is totally enclosed inside one map area.

An area is a portion of the map bounded by lines. All portions of the map must be assigned some area point. Each area is identified in a DLG-3 data file by a point chosen to represent the characteristics of the area. Newer versions of the processing software, the DLG Production system or PROSYS, locate a given area point inside the area it represents, although this is not a structural requirement. Every DLG data file will have at least two areas identified: one representing the area covered by the file and the other representing the area outside the coverage of the file. Additional areas will be identified as necessary to subdivide the 
area covered by the file. Polygons as unique features are not defined explicitly in a DLG file. However, polygons can be constructed using line-area linkages built into the DLG data structure.

\section{ATTRIBUTE CODES}

In addition to locational and topological information, DLG data elements may have explicitly encoded attributes. Attribute codes, also called feature codes or classification attributes, are used to describe the map information represented by a node, area, or line. For example, the attribute code for an area might identify a lake or a swamp; the attribute code for a line might identify a road, railroad, stream, or shoreline; the attribute code for a node might identify the upper origin of a stream (fig. 1). The codes are based on the cartographic features symbolized on the USGS Topographic Map Series. These maps are the basic source material used to digitize and to encode the data elements and therefore the map symbology has a strong influence on the overall classification strategy. A listing of all the attribute codes currently assigned and used in the 1:100,000- scale DLG files is given in Appendix D. Detailed information on how to apply and interpret the attribute coding system is given in Standards for Digital Line Graphs, Part 3: Attribute Coding. (This publication may be purchased from the U.S. Geological Survey. See the Ordering Information inside the front cover.)

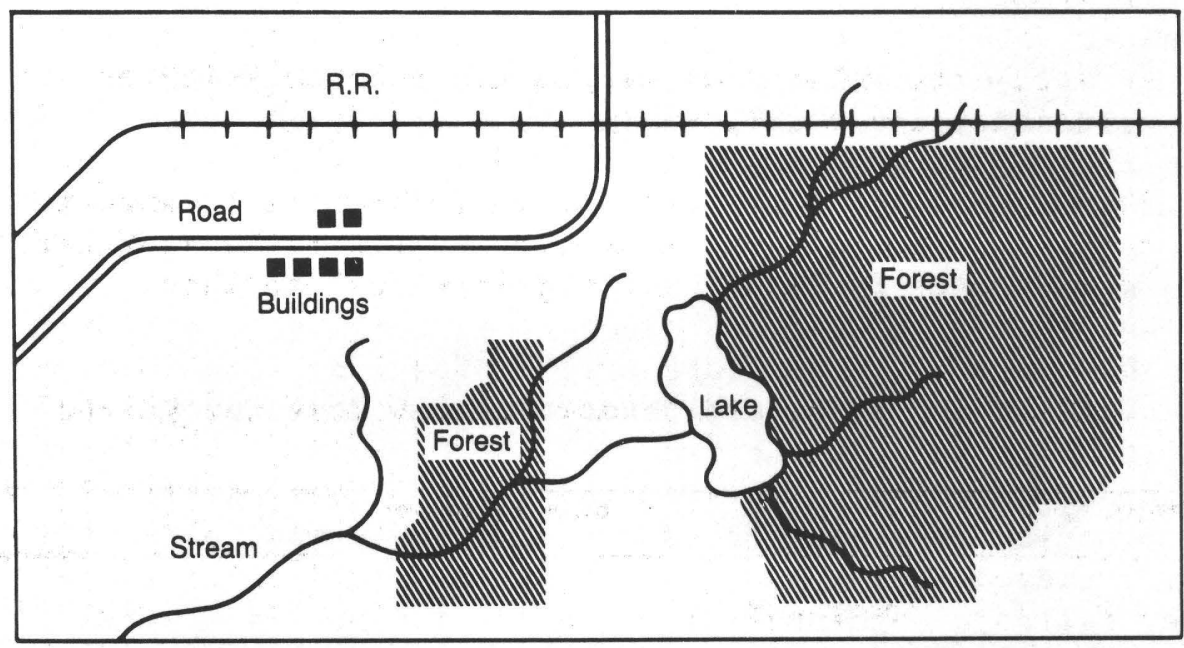

Figure 1.--Map elements showing roads, railroads, buildings, streams and lake and forest areas.

Each attribute code identifies the major category to which a data element belongs, as well as the specific nature of the element. Codes also may provide additional descriptive information. Most elements are uniquely described by a single attribute code. Others, however, may require two or more codes for a complete description. If multiple attributes are needed to describe an element, the order is not usually significant. Allowing for a variable number of attribute codes creates an open-ended structure to which information may be added at any time. It is not necessary for each element to have associated attributes; in general, attribute codes are not assigned to an element if the attributes can be 
derived based on relationships to adjacent elements. For example, the mapped outline of an alkali flat is not assigned an attribute code because the line record carries a reference to the areas to the left and right. One area will be assigned an attribute code identifying the area as "alka$1 i$ flat" and the other will have no attribute, signifying it is background or "nonhydrographic." The fact that the line defines an alkali flat is derivable.

A DLG attribute code is composed of two distinct numeric fields: a threedigit major code, which identifies the major category to which the element belongs, and a four-digit minor code, which specifically describes the element. In the digital file, the major and minor attributes are encoded in two integer fields of six digits, right justified with leading blanks (FORTRAN 2 I6 format). In this document, major codes are presented as three digits, and minor codes are presented as four digits. Leading zeros are shown for clarity; for example: 0500412.

\section{Major Attribute Codes}

A list of the major codes for the categories that are currently being collected is contained in table 1 . The first two digits of the major code uniquely identify the category to which the described element belongs. The third digit of the major code is used to modify the minor code in two ways:

- If zero, the minor code represents a description or classification of the element.

- If nonzero, the minor code which follows is a parameter requiring special interpretation according to instructions given in the codes for each category (see next section).

Table 1.--Major codes used for DLG base categories

\begin{tabular}{|c|c|}
\hline Major Code & Base Category \\
\hline 020 & Hypsography \\
\hline 050 & $\begin{array}{l}\text { Combined hydrography--streams, water bodies, and } \\
\text { wetlands }\end{array}$ \\
\hline 090 & Boundaries \\
\hline $170 *$ & Transportation systems--roads and trails \\
\hline $180 *$ & Transportation systems--railroads \\
\hline $190 *$ & $\begin{array}{l}\text { Transportation systems--pipelines, transmission } \\
\text { lines, and miscellaneous transportation }\end{array}$ \\
\hline 300 & U.S. Public Land Survey system \\
\hline
\end{tabular}

* Transportation systems have been assigned more than one major code so that their components may be readily separated for analytical applications. 


\section{Minor Attribute Codes}

The first digit of the minor code is normally zero. If nonzero, it is used as a modifier to provide additional information such as road access or railroad status.

The remaining three digits are normally used to indicate the cartographic interpretation to be applied to specific elements. The type of element described by a particular code usually can be determined from the range of value of the last three digits:

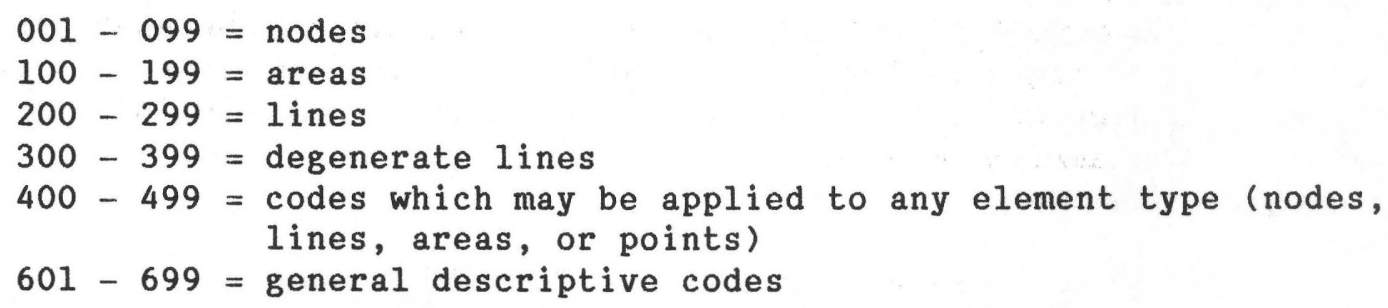

The last three digits (and occasionally all four digits) also may be used as a parameter code. Parameters are used when a minor code can legitimately assume a range of values such as a water elevation or a highway route number. The meaning of a parameter code is indicated by the (nonzero) third digit of the major code.

\section{Sample Attribute Codes}

Three examples using the DLG attribute codes follow and should be interpreted with reference to Appendix D.

Example A:

0500412 The major code 050 indicates the combined hydrography category. The minor code 0412 identifies the feature as a stream.

Example B:

1700201 The major code 170 indicates the roads and trails subcategory in the transportation category. The minor code 0201 identifies the feature as a class 1 highway.

1700603 The major code 170 indicates the roads and trails subcategory in the transportation category. The minor code identifies the feature as a road under construction. This code would be used in addition to the code describing the class of road, and would appear in the same record with the code 1700201 . 
Example C:

0550033 The major code 055 indicates a river mile mark for the hydrography category. Because the last digit of the major code is nonzero, the minor code is a parameter. The minor code 0033 indicates that the value of the river mile mark at that point is 33 .

Example D:

$306 \quad 0033$

The major code 306 indicates an Origin of Survey code for the U.S. Public Land Survey System category. Because the last digit of the major code is nonzero, the minor code 0033 indicates that the area element is referenced to the Willamette Meridian.

\section{SAMPLE LINE GRAPH STRUCTURE}

Examples of a line graph and its corresponding digital records are given in figure 2 and table 2. These examples are simplified representations of the concepts used in the DLG-3 structure; they are not actual data files. The examples shown are composed of 13 nodes, 5 areas, and 15 lines. The 13 nodes are labeled N1 through N13, the 5 areas are labeled A1 through A5, and the 15 lines are labeled L1 through L15. Each element type is maintained as a separate list in the digital data.

The map represented by the example is divided into five distinct areas labeled Al through A5. Area Al represents all the area outside of the map border. There is one outside area for each DLG-3. It is always the first area encountered and has the attribute code 0000000 . In the example given in figure 2, the portion of the map inside the border is divided into four areas, each bounded (closed) by lines. Area A2 is bounded by lines L14, L1, L4, and L5. Area A3 is bounded by lines L3, L13, L4, L6, L7, L8, L15, and L9. Area A4 is bounded by lines L8, L15, and L9. Area A5 is bounded by lines L5, L6, L7, and L10 and L2.

As implemented in the standard DLG-3 data structure, line elements contain the only explicit topological references. Each line contains pointers to its bounding nodes (starting and ending) and the areas that it bounds (left and right of the line). This format minimizes redundant linkages to achieve efficient data encoding and storage.

The lines in figure 2 are labeled L1 through L15. The lines can be identified by their starting node number, ending node number, number of the area to the left of the direction of travel, number of the area to the right of the direction of travel, and string of coordinates describing the alignment of the line. In this example, only two pairs of coordinates are shown; however, in an actual file, an irregular line would have a variable number of coordinate pairs up to a limit of 3,000 coordinate pairs. The direction of travel of the line is arbitrarily determined during the digitizing operation. In this example, L1 is encoded as proceeding clockwise around area A2. Thus line L1 starts at node $\mathrm{N} 1$, ends at node N3, has area A1 to the left of the direction of travel, and has area A2 to the right of the direction of travel. The coordinate string 


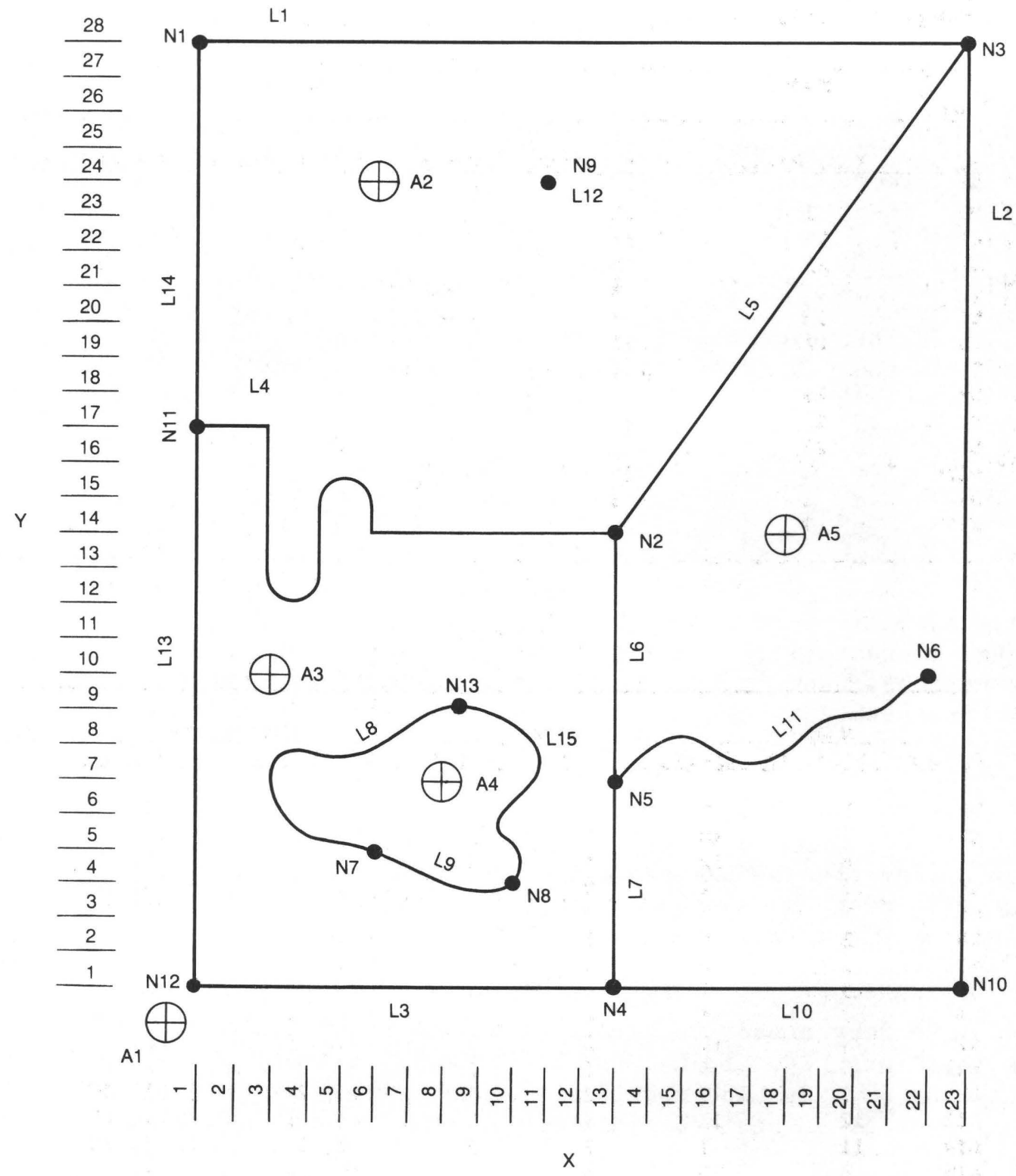

Figure 2.--Sample line graph.

describing the alignment of the line will start with the same coordinate values as that of node $\mathrm{N} 1$ and will end with the same coordinate values as that of node N3. Because the area to the left of its direction of travel, $A 1$, is different from the area to the right of its direction of travel, A2, the line is known to be a boundary between the two areas.

Lines L11 and L12 are examples of lines that lie within one area. In this example, line L11 starts at node N5, ends at node N6, has area $A 5$ to the left of the direction of travel, and again has area A5 to the right of the direction of travel. The coordinate string for the line will start with the same coordinate values as that of node N5 and will end with the same coordinate values as that of node N6. Line L12 is an example of a degenerate line. The line starts at node $\mathrm{N9}$, ends at node $\mathrm{N9}$, and has area $A 2$ as both the area to its left and right. There are only two 
Table 2.--Digital description of sample DLG-3 (see fig. 2)

\begin{tabular}{|c|c|c|c|c|c|}
\hline \multicolumn{3}{|c|}{ Nodes } & \multicolumn{3}{|c|}{ Areas } \\
\hline Number & $\mathrm{X}$ Coordinate & $y$ Coordinate & Number & X Coordinate & Y Coordinate \\
\hline N1 & 1 & 28 & A1 & 0 & 0 \\
\hline N2 & 13 & 14 & A2 & 6 & 24 \\
\hline N3 & 23 & 28 & A3 & 3 & 10 \\
\hline N4 & 13 & 1 & A4 & 8 & 7 \\
\hline N5 & 13 & 7 & A5 & 18 & 14 \\
\hline N6 & 22 & 10 & & & \\
\hline N7 & 6 & 5 & & & \\
\hline N8 & 10 & 4 & & & \\
\hline N9 & 11 & 24 & & & \\
\hline N10 & 23 & 1 & & & \\
\hline N11 & 1 & 17 & & & \\
\hline N12 & 1 & 1 & & & \\
\hline N13 & 9 & 9 & & & \\
\hline
\end{tabular}

Lines

\begin{tabular}{|c|c|c|c|c|c|c|c|}
\hline \multirow[b]{2}{*}{ Number } & \multicolumn{2}{|l|}{ Nodes } & \multicolumn{2}{|c|}{ Area } & \multicolumn{3}{|c|}{ Coordinates } \\
\hline & starting & Ending & Left & Right & (first $x$ & & last $x y$ ) \\
\hline LI & 1 & 3 & 1 & 2 & 1,28 & & 23,28 \\
\hline L2 & 3 & 10 & 1 & 5 & 23,28 & & $23, \quad 1$ \\
\hline L3 & 4 & 12 & 1 & 3 & 13,1 & & 1,1 \\
\hline L4 & 11 & 2 & 2 & 3 & 1,17 & $\ldots$ & 13,14 \\
\hline L5 & 2 & 3 & 2 & 5 & 13,14 & & 23,28 \\
\hline L6 & 2 & 5 & 5 & 3 & 13,14 & & 13,7 \\
\hline L7 & 5 & 4 & 5 & 3 & 13,7 & & 13,1 \\
\hline L8 & 13 & 7 & 4 & 3 & 9 & $\ldots$ & 6,5 \\
\hline L9 & 7 & 8 & 4 & 3 & 6 , & $\ldots$ & 10,4 \\
\hline L10 & 4 & 10 & 5 & 1 & 13 & & $23, \quad 1$ \\
\hline L11 & 5 & 6 & 5 & 5 & 13,7 & $\ldots$ & 22,10 \\
\hline LL12 & 9 & 9 & 2 & 2 & 11,24 & & 11,24 \\
\hline L13 & 12 & 11 & 1 & 3 & 1,1 & & 1,17 \\
\hline L14 & 11 & 1 & 1 & 2 & 1,17 & & 1,28 \\
\hline L15 & 8 & 13 & 4 & 3 & 10,4 & $\ldots$ & 9,9 \\
\hline
\end{tabular}

coordinate pairs in the string defining the line: both points have the same coordinate values as node $\mathrm{N9}$; thus, the two points are the same and the line has zero length.

The line graph concept allows all of the points on the map to be described as a member of a line graph element (node, area, or line) with minimal redundancy. The relationships between the various elements are indicated by the structure. Note that in this example the $\mathrm{x}$ and $\mathrm{y}$ coordinates are numbered from the lower left corner to simplify the drawing. In an actual DLG-3 file, the origin is the center of the map and the internal file coordinates are numbered plus or minus 1 to 32,767 in thousandths of inches. See the section labeled "coordinate systems" for more detail. 
The digital line graph concept is based on graph theory, in which a diagram can be expressed as a set of elements (nodes, areas, and lines) in a manner that shows logical spatial relationships with minimal redundancy. There are three ways to implement the line graph concept in DLG files: the area case, the network case, and the area-hybrid case. These cases are differentiated by the nature of the information contained in the category. Currently all NMD files are processed as area-hybrid case DLG's.

\section{Area Case}

Area line graphs can be used to represent area features such as political entities or the U.S. Public Land Survey system. In the pure area case, each line element bounds two different area elements, all closed circuits of lines form unique areas, and all areas are attribute coded. Line elements for area line graphs are not usually assigned primary attributes. The primary attribute characteristics of lines in these categories are derived by examining the attributes of the area elements on either side of the lines.

\section{Network Case}

Network line graphs can be used to represent linear features such as roads, railroads, or pipelines. The major topological relationship expressed by network data is that of connectivity. The network case differs from the area case in that, irrespective of the number of closed areas forming the graph, only two areas are encoded: (1) the area outside the graph, termed the outside area; and (2) the area within the graph, termed the background area. All lines except the graph boundary, or neatline, are considered to be contained within the background area. Lines may exist within the background area that are not part of closed line circuits. In the pure network case, the lines themselves have the identity and carry the appropriate attribute codes. Data encoded in network line graph form are suitable for various forms of network analysis, such as minimum path computations.

\section{Area-Hybrid Case}

In the area-hybrid case, network and area type information are gathered in a single DLG file. In this approach, all closed circuits of lines define unique areas. The unique areas which represent features for the overlay are given attribute codes. The remaining areas are recognized in processing as individual unattributed background areas. Linear features may exist which do not form boundaries between two areas. These lines may occupy a position in an unattributed background area, or in an attributed area. Lines that have significance in themselves are assigned attribute codes. For example, in the hydrography overlay, areal features such as lakes and swamps will be encoded with the appropriate attributes; surrounding nonhydrographic areas will be uncoded. Linear features such as 
streams and aqueducts receive the appropriate line code; unattributed lines may also exist (e.g. around defined areal features such as an alkali flat).

Figure 3 shows a 7.5-minute window taken from the Cartersville, Ga., 1:100,000-scale quadrangle. Figure 4 shows the line graph encoded for the hydrography of the same area. Certain nodes, areas, and lines are labeled.

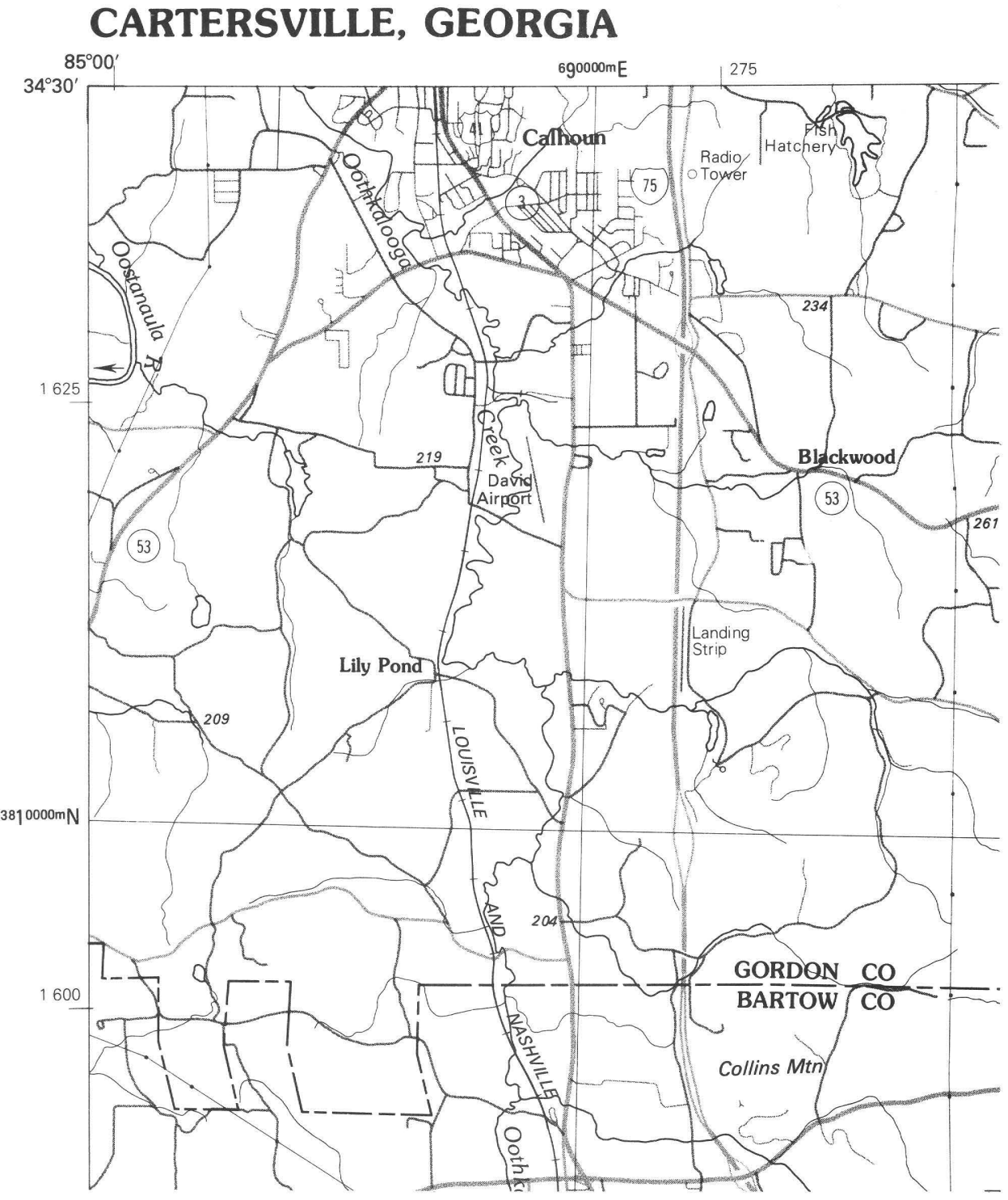

Figure 3.--Window from the Cartersville, Ga., 1:100,000-scale USGS quadrangle map. 


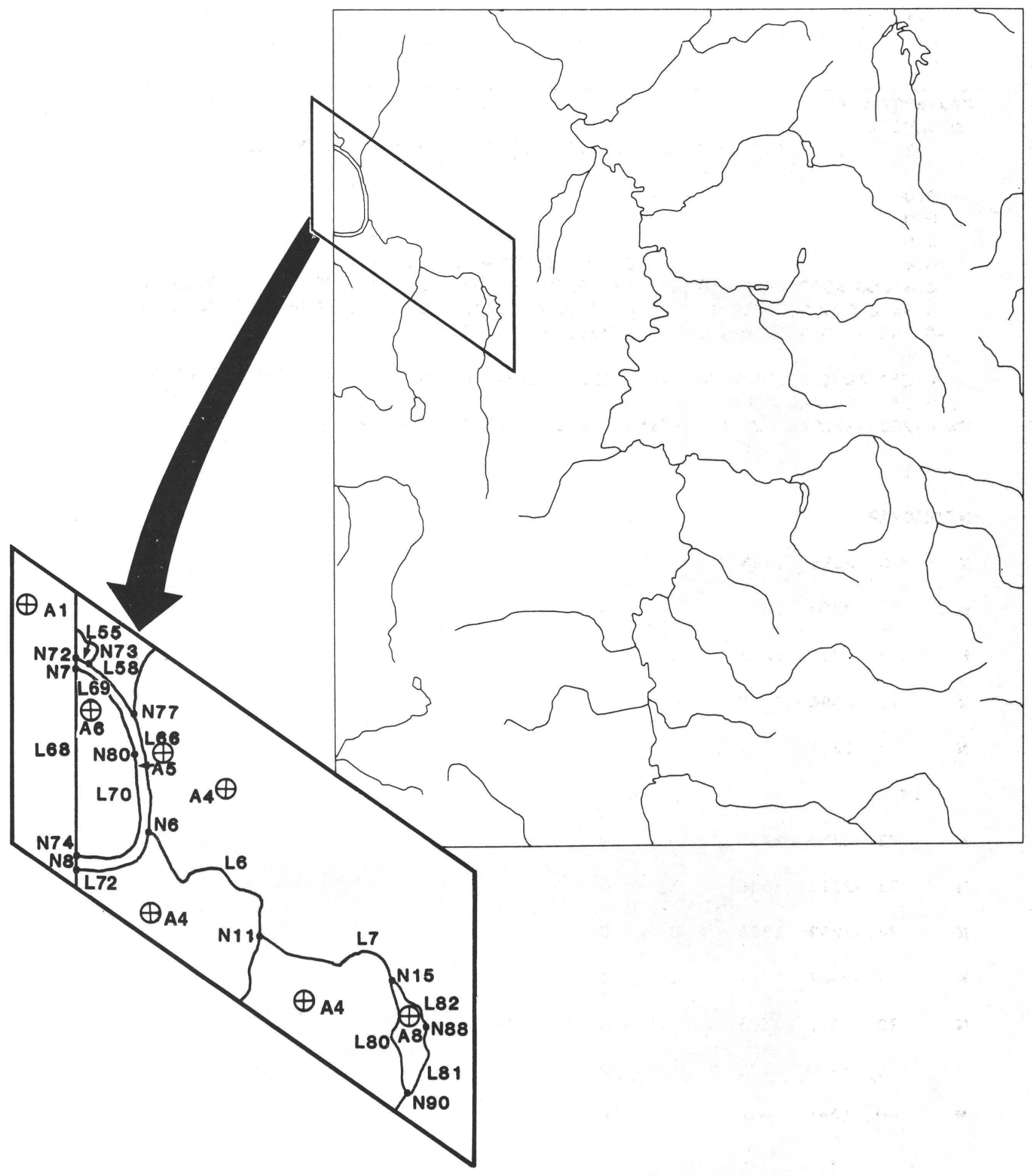

Figure 4.--Plot from line graph of hydrography, Cartersville, Ga., 7.5-minute section of quadrangle, with enlarged detail.

Table 3 contains some of the digital data records, extracted from the standard format DLG file, which describe this portion of the graph. The internal sequence identification numbers shown reflect the order of these features in the original file. (Note: Descriptions of DLG-3 formats are contained in Appendixes $A$ and $B$, and a list of attribute codes is contained in Appendix D.) 
Table 3.--Selected sample of standard format DLG-3 records of Cartersville, Ga., 7.5-minute section of quadrangle

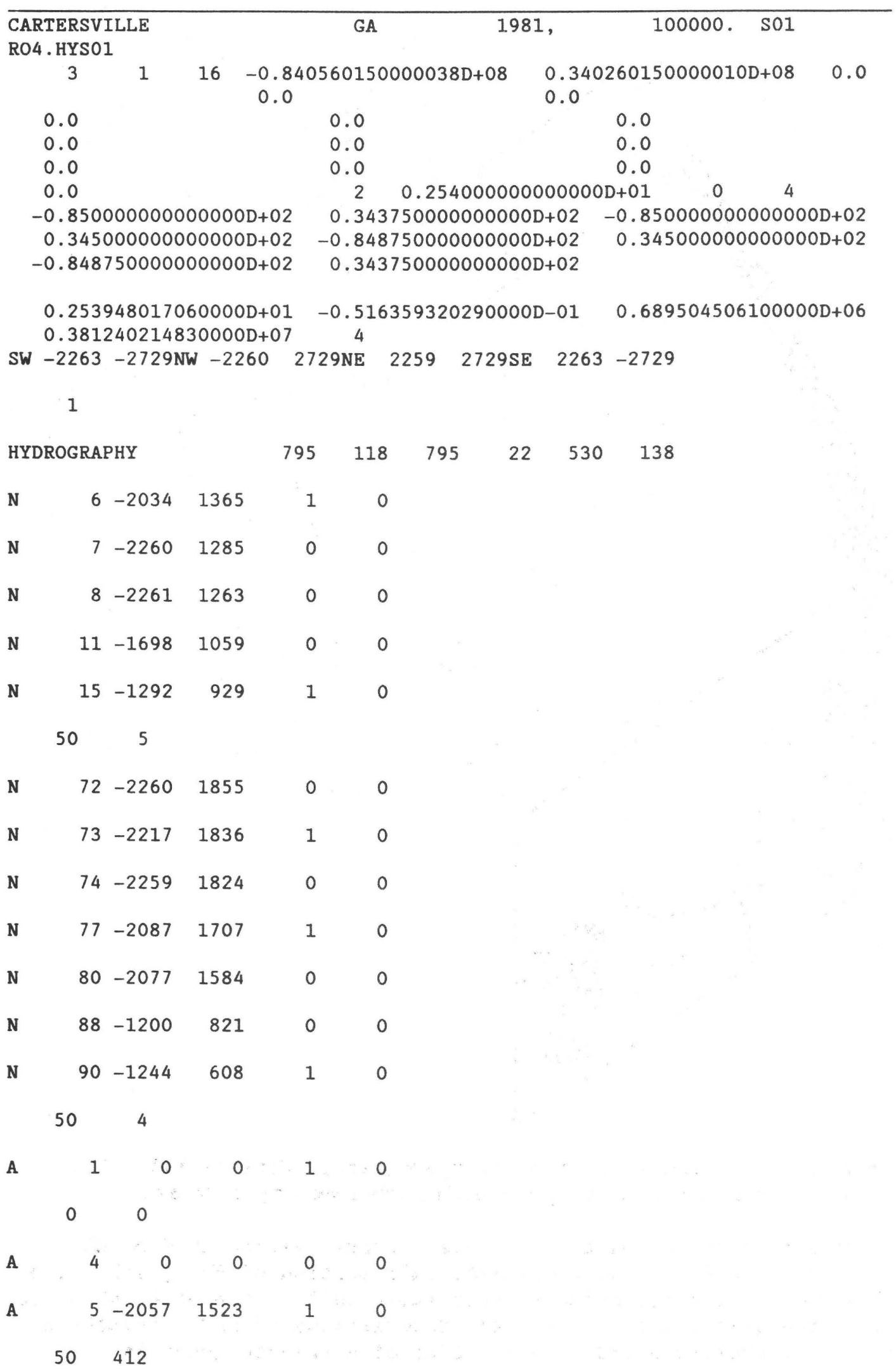


Table 3.--Selected sample of standard format DLG-3 records of Cartersville, Ga., 7.5-minute section of quadrangle--continued

\begin{tabular}{|c|c|c|c|c|c|c|c|c|c|c|c|}
\hline A & 6 & 0 & 0 & 0 & 0 & & & & & & \\
\hline A & $8-124$ & 43 & 10 & 1 & 0 & & & & & & \\
\hline 50 & 421 & & & & & & & & & & \\
\hline L & 6 & 11 & 6 & 4 & 4 & 21 & 1 & 0 & & & \\
\hline-1698 & 1059 & -1699 & 1115 & -1686 & 1140 & -1686 & 1178 & -1698 & 1193 & -1718 & 1203 \\
\hline-1777 & 1216 & -1792 & 1238 & -1838 & 1257 & -1902 & 1243 & -1910 & 1236 & -1911 & 1212 \\
\hline-1920 & 1208 & -1929 & 1214 & -1957 & 1249 & -1957 & 1253 & -1981 & 1281 & -2010 & 1333 \\
\hline-2009 & 1351 & -2014 & 1361 & -2034 & 1365 & & & & & & \\
\hline 50 & 412 & & & & & & & & & & \\
\hline
\end{tabular}

$\begin{array}{lllllllll}\mathrm{L} & 7 & 15 & 11 & 4 & 4 & 17 & 1 & 0\end{array}$

$\begin{array}{rrrrrrrrrrrr}-1292 & 929 & -1295 & 951 & -1306 & 973 & -1308 & 987 & -1321 & 1000 & -1359 & 1019 \\ -1416 & 1017 & -1430 & 1008 & -1434 & 1000 & -1455 & 981 & -1469 & 988 & -1482 & 1000 \\ -1524 & 994 & -1576 & 1002 & -1644 & 1034 & -1669 & 1050 & -1698 & 1059 & & \\ 50 & 412 & & & & & & & & & & \\ \end{array}$

$\begin{array}{lllllllll}\mathrm{L} & 55 & 73 & 72 & 5 & 18 & 2 & 1 & 0\end{array}$

$-2217 \quad 1836-2260 \quad 1855$

$50 \quad 606$

$\begin{array}{lllllllll}\mathrm{L} & 58 & 77 & 73 & 5 & 4 & 5 & 1 & 0\end{array}$

$\begin{array}{llllllllll}-2087 & 1707 & -2116 & 1746 & -2164 & 1801 & -2213 & 1828 & -2217 & 1836\end{array}$

$50 \quad 606$

$\begin{array}{llllllllll}\text { L } & 66 & 6 & 77 & 5 & 4 & 7 & 1 & 0\end{array}$

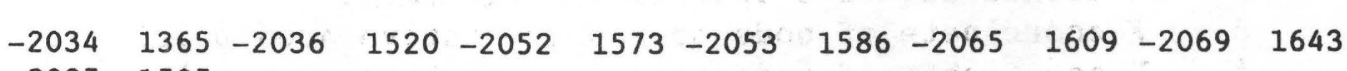

$-20871707$

$50 \quad 606$

L $\begin{array}{llllllllll}68 & 74 & 7 & 1 & 6 & 2 & 0 & 0\end{array}$

$\begin{array}{llll}-2260 & 1285 & -2259 & 1824\end{array}$

$\begin{array}{llllllllll}\text { L } & 70 & 74 & 80 & 6 & 5 & 10 & 1 & 0\end{array}$

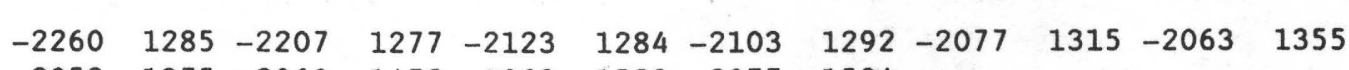

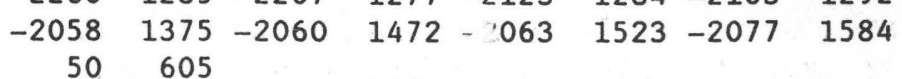

$\begin{array}{lllllllll}\text { L } & 69 & 80 & 7 & 6 & 5 & 11 & 1 & 0\end{array}$

$\begin{array}{rrrrrrrrrrrr}-2077 & 1584 & -2082 & 1616 & -2085 & 1619 & -2087 & 1637 & -2094 & 1652 & -2098 & 1675 \\ -2107 & 1695 & -2161 & 1763 & -2209 & 1801 & -2244 & 1820 & -2259 & 1824 & & \\ 50 & 605 & & & & & \end{array}$ 
Table 3.--Selected sample of standard format DLG-3 records of

Cartersville, Ga., 7.5-minute section of quadrangle--continued

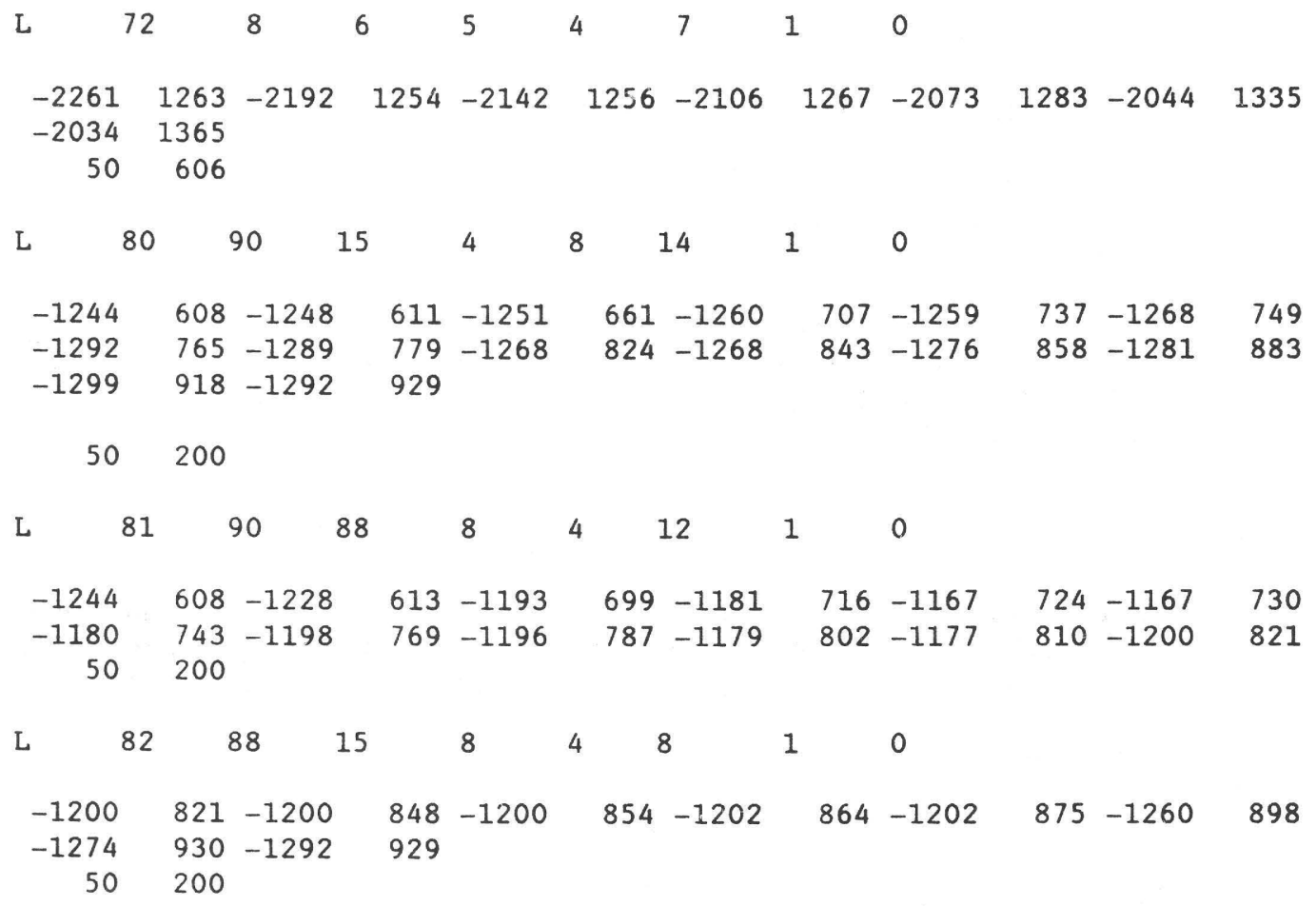

In the Cartersville example, each node and area element is described by one or two logical records: (1) a type D.I record that describes the element, and (2) an optional type F record that lists the attribute codes associated with the element. The first record (type D.1) for each node and area element contains the following fields:

1. Type of record indicator, $\mathbf{N}$ for node or $\mathrm{A}$ for area.

2. Internal sequence identification number.

3. X-coordinate of node or representative area point.

4. Y-coordinate of node or representative area point.

5. Number of attribute codes that describe the element.

6. Number of pairs of characters in the text string that describes the element.

The second record (type $F$ ) for each node and area element contains $n$ attribute codes (expressed as major and minor code pairs), where $\mathrm{n}$ is the number specified in field 5 of the first (type D.1) record.

Each line element in the Cartersville example is described by two or three logical records: (1) a type D.2 line description record, and (2) a type E record that lists the $\mathrm{x}, \mathrm{y}$ coordinate pairs that define the shape of the line, and, if appropriate, (3) a type $F$ (attribute code) record. The first record (type D.2) for each line element contains the following fields:

1. Type of record indicator (L).

2. Internal sequence identification number.

3. Internal sequence number of starting node. 
4. Internal sequence number of ending node.

5. Internal sequence number of the area to the left of the line.

6. Internal sequence number of the area to the right of the line.

7. Number of $x, y$ coordinate pairs that locate the line on the map.

8. Number of attribute codes that describe the line.

9. Number of pairs of characters in the text string that describes the line.

The second logical record (type E) for each line element contains $n$ coordinate pairs, where $n$ is the number specified in field 7 of the first (type D.2) record. The type F record is as described above.

The specific records listed in table 3 completely describe several hydrographic features in the upper left section of figure 3 , the Oostanaula River, a small irregularly shaped lake, and the single line stream flowing from the lake to the river. The records referred to in the following description have been extracted from a complete DLG. Therefore the internal sequence identifiers reflect the original order of the features in the file. The records are referred to by the internal sequence number, e.g., area 4 , node 77 , line 82 .

The double line stream, Oostanaula River, is represented by area record 5 and identified by the attribute code 050 0412. Area records 4 and 6 are the background areas on either side of the river and as such have no attribute code assigned. The area outside of the map is represented by area record 1 and is identified by the attribute code 00 .

Line records 55, 58, 66, and 72 form the left bank of the river, coded as though one were facing downstream. They are identified by the attribute code 0500606 . They can be chained by referring to the nodes. Line record 72 starts at node 8 and ends at node 6 . Line record 66 starts at node 6 and ends at node 77 . Line record 58 starts at node 77 and ends at node 73 . Line record 55 starts at node 73 and ends at node 72 .

The right bank of the river is formed in a similar fashion by line records 69 and 70 , which are identified by the attribute code 0500605 . They are similarly linked through the nodes 7,80 , and 74 . Note that the identity of the shoreline as either left or right bank, (coded as such to indicate downstream flow), is established by the attribute code without changing the identity of the feature. The given line segments making up the shore may be digitized in either direction. The segment of neatline represented by line record 68 stretches from node 7 to node 74 , the two places where the right bank intersects the neatline. The neatline has no attribute code assigned but can be identified by the fact that the area on one side of it is the outside area, area 1.

Area record 8 is the irregularly shaped lake. It is identified by attribute code 050.0421. Its shoreline is formed by line records 80,81 , and 82, which are identified by attribute code 050.0200 . These lines also can be identified as bounding area 8 , by reference within the line record to area 8 being located either to the left or right of the line (depending on which way the digitizer traced each line). The lines can be chained by referring to the starting and ending nodes 90,15 , and 88 . 
The single-line stream that flows from the lake to the Oostanaula River is represented by 1 ine records 6 and 7 and identified by attribute code 050.0412. One stream segment connects to the lake at node 15 and one to the left river bank at node 6 . The segments of the stream are themselves linked at node 11. Note that this stream has the same attribute code as the river. This is because both are streams, one of which is digitized as a line and one of which is digitized as an area and its delimiting banks. The direction of flow of this stream can be derived from the fact that node 15 is identified with attribute code 050.0005 (stream exiting hydrographic area). Background area 4 is located on both sides of the stream.

\section{DISTRIBUTION FORMATS}

The 1:100,000-scale DLG data are available in two distribution formats: (1) standard and (2) optional.

The standard distribution format is intended to minimize storage requirements. Explicit topological linkages are contained only in the line elements (starting node, ending node, area to the left of direction of travel, area to the right of direction of trave1). A sample DLG in standard format is found in Appendix A.

The optional distribution format was designed to facilitate data usage. The topological relationships explicitly encoded include starting node, ending node, area to the left of direction of travel and area to the right of direction of travel for line elements, bounding lines for area elements, and bounding lines for node elements. These files are typically larger than those in the standard format but, for certain applications, can simplify processing requirements. For example, topological linkages are explicitly encoded for all line, node, and area elements, allowing a polygon data structure to be easily created. These linkages facilitate GIS applications of DLG data as well as generation of graphic products. A sample DLG in optional format is found in Appendix B.

The characteristics of the standard and optional DLG formats are summarized below in table 4 .

\section{SOURCE MATERIALS}

The DLG data files described in this document are derived from USGS topographic maps published as 30- x 60-minute quadrangles at $1: 100,000-$ scale. Where 1:100,000-scale coverage is not available, the following sources are used, in order of preference:

1. Bureau of Land Management editions of $1: 100,000-$ scale maps,

2. Archival compilation materials, if available. 
Table 4.--Standard and optional DLG format

\begin{tabular}{|c|c|c|}
\hline & Standard & Optional \\
\hline Character set & 8-bit ASCII & 8-bit ASCII \\
\hline $\begin{array}{l}\text { Logical record } \\
\text { length }\end{array}$ & 144 bytes & 80 bytes \\
\hline $\begin{array}{l}\text { Physical record } \\
\text { length (blocksize) }\end{array}$ & $\begin{array}{l}\text { variable in } \\
\text { multiples of } \\
144 \text { bytes }\end{array}$ & $\begin{array}{l}\text { variable in } \\
\text { multiples of } \\
80 \text { bytes }\end{array}$ \\
\hline Coordinate system & $\begin{array}{l}\text { internal file } \\
\text { (thousandths of } \\
\text { a map inch) }\end{array}$ & $\begin{array}{l}\text { ground } \\
\text { planimetric } \\
\text { (UTM) }\end{array}$ \\
\hline $\begin{array}{l}\text { Topological } \\
\text { linkages }\end{array}$ & $\begin{array}{l}\text { contained only } \\
\text { in line elements }\end{array}$ & $\begin{array}{l}\text { contained in } \\
\text { node, area, and } \\
\text { line elements }\end{array}$ \\
\hline
\end{tabular}

These formats are described in detail in Appendixes $A$ and $B$.

The scale of the source materials used to generate a DLG is contained in the file header. The scale is also reflected in the resolution field, which states the ground length in meters of the smallest data collection unit 0.001 inch $(2.54 \mathrm{~m})$.

\section{CELL SIZE AND FILE EXTENT}

The DLG's are distributed in groups of files that make up a 30- $x$ 30minute area of coverage representing the selected category of information in the east half or west half of a 1:100,000-scale source map. Each 30minute area consists of a varying number of DLG files depending on the category and the feature density. The normal distribution group will be four 15-minute files per 30-minute area. If the feature density in an area is such that the file size would exceed the limitations of the processing programs, then that 30 -minute area will be covered by sixteen 7.5-minute files. This seldom occurs except in the case of roads and trails in large cities.

For the categories currently available, the 30-minute area of coverage will comprise the following: 


\begin{tabular}{|c|c|c|}
\hline Category & $\begin{array}{l}\text { Number of } \\
\text { files }\end{array}$ & Size \\
\hline \multicolumn{3}{|l|}{ Hydrography } \\
\hline Normal & 4 & 15 minute \\
\hline Very Dense & 16 & 7.5 minute \\
\hline \multicolumn{3}{|l|}{ Transportation } \\
\hline \multicolumn{3}{|l|}{ Normal } \\
\hline Roads and trails & 4 & 15 minute \\
\hline Railroads & 4 & 15 minute \\
\hline $\begin{array}{l}\text { Pipelines, Transmission } \\
\text { Lines and Miscellaneous } \\
\text { Transportation }\end{array}$ & 4 & 15 minute \\
\hline \multicolumn{3}{|l|}{ Very Dense } \\
\hline Roads and trails & 16 & 7.5 minute \\
\hline Railroads & 4 & 15 minute \\
\hline Pipelines, etc. & 4 & 15 minute \\
\hline \multicolumn{3}{|l|}{ Hypsography } \\
\hline Normal & 4 & 15 minute \\
\hline Very dense & 16 & 7.5 minute \\
\hline \multicolumn{3}{|l|}{ Boundary* } \\
\hline Normal & 4 & 15 minute \\
\hline \multicolumn{3}{|l|}{ PLSS* } \\
\hline Normal & 4 & 15 minute \\
\hline \multicolumn{3}{|c|}{$\begin{array}{l}\text { * Boundary and PLSS overlays are by nature less dense and will } \\
\text { always be contained within four } 15 \text {-minute files. }\end{array}$} \\
\hline
\end{tabular}

The quadrangle name field in the header record will contain the name of the 1:100,000-scale source map. However, the pieces or sections into which each is divided are identified within the header (A) record to the size and placement of each. In column 64-66, each section will be identified by a 3-character code XNN where:

$X$ is a single letter indicating size

$\mathrm{F}=$ Fifteen (15) minute block

$S=$ Seven and a half $(7.5)$ minute block

NN is a two-digit number indicating the specific quad. Figure 5 illustrates this division with the sections labeled with the code that would appear in column 64-66 of the header record.

If data for a particular category exist only in a portion of a 30-minute area, the entire area will be digitized. The 7.5- or 15-minute sections which contain no feature in the given category will be digitized as "null" or empty files. This means they will contain the neatline records, inside 


\begin{tabular}{|c|c|c|c|}
\hline F01 & F02 & F03 & F04 \\
\hline F05 & F06 & F07 & F08 \\
\hline
\end{tabular}

A 1;100,000-scale quad divided into eight 15-minute quads, 4 per 30 -minute area.

\begin{tabular}{|l|l|l|l|l|l|l|l|}
\hline S01 & S02 & S03 & S04 & S05 & S06 & S07 & S08 \\
\hline S09 & S010 & S011 & S012 & S013 & S014 & S015 & S016 \\
\hline S017 & S018 & S019 & S020 & S021 & S022 & S023 & S024 \\
\hline S025 & S026 & S027 & S028 & S029 & S030 & S031 & S032 \\
\hline
\end{tabular}

A 1:100,000-scale quad divided into 32 7.5-minute quads, 16 per 30 -minute area.

Figure 5.--Sectioning scheme for DLG data of a $1: 100,000-$ scale quadrangle.

area record, and outside area records only in order to indicate the absence of any features in that category in that location. The remaining 7.5- or 15-minute sections which contain features in that category will be digitized as usual.

If no data for a particular category exist in an entire 30-minute area the entire 30-minute area will not be digitized. This occurs on coastal areas where an entire 30-minute area may be ocean, or along the national boundary where an entire 30-minute area may lie outside the United States. Data are not currently collected in Canada or Mexico. At some time in the future, the non-U.S. areas will be digitized and added to the NDCDB.

Nonstandard cells are not collected. In areas where map format is sometimes extended to conform to the shoreline or national boundary, the portion of the map that extends beyond the normal size is digitized as a separate file. Such cells are readily identified by examining the geographic coordinate limits contained in the file header. Such files may also be identified by the name which will be formed by adding descriptive information to the map name, such as "Mt. Baker O.E. N" (Mt. Baker over-edge North).

\section{Preliminary Data}

In mid-1986, the U.S. Geological Survey released a preliminary version of DLG's from 1:100,000-scale maps. These data differ in format from those previously described. Specific characteristics of these preliminary data are given below.

1. These data are topologically structured, attribute coded, and will be distributed in standard or optional DLG format. 
2. The DLG's are distributed in groups of files that make up a 30by 30-minute area of coverage representing a category of information in the east half or west half of a 1:100,000-scale source map. The distribution groups for both roads and trails, and hydrography will consist of sixteen 7.5-minute files (rather than four 15-minute files).

3. Railroad and miscellaneous transportation data consisting of a single 30-minute file will contain a 3-character TNN code in columns $64-66$ of the header (A) record where:

$\mathrm{T}=$ Thirty-minute (30) block

NN = A two-digit number indicating the West (01) or

East (02) half of a 1:100,000-scale graphic.

4. Preliminary data have not been processed through edge-matching software and will not include edge-join quality control flags.

The USGS is currently involved in a program to reformat data, originally available for distribution in preliminary format, to standard cell size. Data that have been processed through edge-matching software and reformatted to the standard cell size automatically supercede preliminary format data.

\section{COORDINATE SYSTEMS}

The positional descriptions for DLG data elements are expressed in one of two coordinate systems, dependent upon the distribution format selected. These are described as follows as the standard distribution format and the optional distribution format.

\section{Standard Distribution Format}

The DLG data in the standard distribution format are encoded using an internal file coordinate system to minimize storage requirements. The characteristics of this system are as follows:

1. The coordinate system is Cartesian.

2. The origin $(x=0, y=0)$ is at the center of the cell.

3. The $x$-axis of the coordinate system is parallel to a theoretical straight line connecting the southwest and southeast corners of the cell, y-axis is perpendicular to that line.

4. One unit is equal to 0.001 -inch at map scale.

5. The coordinate domain is limited to the range -32767 to +32767 .

The file header contains the parameters of a transformation which can be used to convert the internal file coordinates to the ground coordinate system, which is the Universal Transverse Mercator (UTM) for 1:100,000scale DLG's. An example of this transformation is given in Appendix $E$. 


\section{Optional Distribution Format}

The DLG data in the optional distribution format are expressed in the units of the ground coordinate system, that is, meters in the UTM coordinate system.

\section{DATA VALIDATION}

The DLG data do not currently carry quantified accuracy statements. The following procedures, however, are used to validate the data files before they are released for distribution:

1. File fidelity and completeness -- The data are either manually digitized using equipment with a resolution of 0.001 inch and an absolute accuracy of from 0.003 to 0.005 inch, or are scanned on an automatic device with a resolution of 30 points per millimeter, or $0.0013 \mathrm{inch}$. The positional accuracy of the data and completeness of the file are checked by visually comparing proof plots with the original stable-base source material. These proof plots are generated using automated drafting machines with a resolution of 0.001 inch and an absolute accuracy of from 0.003 to 0.005 inch.

2. Attribute accuracy -- DLG attribute codes are checked by software against a table of valid codes to ensure that each attribute in a file is valid for the category and element type to which it is assigned. Validating the codes for correct application is currently a manual process involving the correlation of formatted listings with proof plots and graphic displays.

3. Topological fidelity -- The topological structure of each DLG file is fully validated by software. There are no extraneous intersections; that is, a line does not join or cross another line, or itself, except at a node. No line extends through a node. Polygon (area) adjacency is also validated; that is, area left and right topological attributes of lines are consistent throughout the file. The neatline is free of gaps. Validation of DLG data is performed for each category within a file.

Additional data validation is being implemented as follows:

1. Edge matching -- Validation software provides for checking the edges of each quadrangle against the edges of the four adjacent quadrangles. Each edge of a DLG-3 is checked for positional and attribute matching along the neatlines of the adjoining DLG-3 cells, providing that the surrounding data cells are available at the time the DLG-3 is entered into the NDCDB. There is currently no attempt, other than the coding of coincident features, to provide fully integrated data categories.

2. Quality Control Flags -- Information in the header of the DLG-3 indicates the status of the file with respect to the edge matching described above. Twelve bytes at the end of record A.1 in the standard distribution format and at the end of record 3 in the optional distribution format of the ASCII file are set aside for quality control flags (see Appendices $A$ and $B$ ). The first three 
of these flag positions are for future use. The fourth flag position contains a value encoded in the bit pattern that is used only by the data base manager to check the edge status. The remaining eight flags indicate to the user the edge status code and the status reason code. The four status flags contain the status of the West, North, East, and South edges of a DLG-3 as compared to the edges of the four adjoining DLG-3 files. Each of the four flags is followed by a status reason code that explains the status of the four edges respectively.

The possible status values for a DLG-3 entered into the NDCDB are:

$$
\begin{aligned}
(\text { blank }) & =\text { unchecked } \\
0 & =\text { passed edge match check } \\
1 & =\text { alignment discontinuity } \\
2 & =\text { attribute discontinuity } \\
3 & =\text { attribute and alignment discontinuity }
\end{aligned}
$$

The possible reason flags are:

$$
\begin{aligned}
\text { (blank) } & =\text { no reason code set ("unchecked" for some earlier data sets) } \\
4 & =\text { adjacent data do not exist } \\
5 & =\text { adjacent data unavailable } \\
6 & =\text { graphic discontinuity } \\
7 & =\text { mismatch valid } \\
8 & =\text { paneling unauthorized }
\end{aligned}
$$

The following combinations of status flags and reason flags are currently valid for the processing software.

$$
\begin{aligned}
& \text { blank,blank blank, } 4 \text { blank, } 5 \text { blank, } 8 \\
& 0, \text { blank } \\
& 1,6 \quad 1,7 \\
& 2,6 \quad 2,7 \\
& 3,6 \quad 3,7
\end{aligned}
$$

The following is a brief explanation of the reason flags.

4 = adjacent data do not exist -- This flag is used with a status flag of blank (unchecked). This combination exists primarily for file edges which are adjacent to areas unmapped within the series/scale of products being digitized, e.g. coastal and international boundary locations. These flags are also used for Public Land Survey System (PLSS) file edges which border areas of the country not having PLSS information.

5 = adjacent data unavailable -- This flag is used with a status flag of blank (unchecked). This flag is appropriate for edges adjacent to areas having similar source material and data categories, but which have not been digitized and archived. A reason code with the value of 5 may be reset as the adjoining data cell becomes available for edge match verification.

6 = graphic discontinuity -. This flag indicates a discontinuity in classification or alignment between features on adjacent graphics which were digitized as represented. 
7 = mismatch valid -- This reason flag applies in the case of a linear graph element ending precisely on the neatline or having a reasonable attribute value change as it crosses the neatline, (e.g. a single line stream ending on the neatline, a road changing from third to fourth class at the neatline).

8 = panelling unauthorized -- This flag is used with the edge status flag of blank and indicates that no authorization was in place for edge matching at the time the data were archived.

This flag is to be used when adjoining quads do not match in cell size (e.g. the situation internal to a 1:100,000-scale project, where a standard 15-minute distribution file adjoins four 7.5-minute files, which cannot at this time be merged into standard 15-minute format because of the density of the data).

In the course of checking and aligning an edge, it is possible to encounter more than one reason for a mismatch status, such as both valid and graphic discontinuities. In such cases the reason flag is to be set to indicate the "worst case," i.e. the reason indicating the most serious problem with the edge and which in most cases would require some degree of correction in the future. For the above example, the graphic discontinuity reason flag would be set in preference to the mismatch valid flag.

When an edge status code is other than "O", the DLG-3 file will be entered into the DCDB only when the reason code has also been set as a result of examination of the file. 
APPENDIXES 


\section{APPENDIX A.--Standard DLG Distribution Format \\ (Record Contents)}

In the standard DLG format, the topological linkages are contained only in the line elements. The files are physically comprised of standard ASCII characters organized into fixed-length logical records of 144 characters. Nine distinct record types are defined.

\section{Logical record type}

A

B

C

D. 1

D. 2

E

F

G

$\mathrm{H}$
Content

Header record containing DLG identification information.

Header record containing projection information and registration points.

Header record identifying data categories contained in this DLG and indicating the number of nodes, areas, and lines in each category .

A node or an area record.

A line record.

Record containing $x, y$ coordinate strings.

Record containing attribute codes.

Record containing text string (not currently used).

Accuracy estimate (not currently used). 
APPENDIX A.--Standard DLG Distribution Format

(Record Contents)--continued

The actual sequence of records in a standard distribution DLG file is as follows :

1. Header records

Type A (one record)

Type B (one record)

Type C (one record)

2. Data records Node records

Node description (D. I)

Attribute codes (F)

Text string (G)

Repeated

for each

node within a

data category

Area records

Area description (D.1) Repeated

Attribute codes (F)

Text string (G)

for each

area within a

data category

Line records

Line description (D.2)

Repeated

$X, Y$ coordinates (E)

for each

Attribute codes (F)

line within a

Text string (G)

data category

3. Accuracy estimate

Type H (one record) (not currently used)

Descriptions of the contents of records A-F are contained in the following tables. The tables also reflect the relationship between these record types and 144-byte logical records. 
APPENDIX A.--Standard DLG Distribution Format (Record Contents)--continued

[Integer fields with a value of zero will have leading zeros suppressed.

[Any field with the format of D24.15 which has a value of zero will be

represented as "bbbo.Obbbbbbbbbbbbbbbbb", the last four positions

of the fractional portion being reserved for a decimal exponent. ( $b=b$ lank)]

\begin{tabular}{|c|c|c|c|c|c|c|c|}
\hline & \multirow[b]{2}{*}{$\begin{array}{l}\text { Data } \\
\text { Element }\end{array}$} & \multicolumn{5}{|c|}{ Logical Record Type A } & \multirow[b]{2}{*}{ Comment } \\
\hline $\begin{array}{l}\text { Record } \\
\text { Number }\end{array}$ & & Contents & $\begin{array}{c}\text { Type } \\
\text { (Fortran Notation) }\end{array}$ & Format & $\begin{array}{l}\text { Starting } \\
\text { Byte }\end{array}$ & $\begin{array}{l}\text { Ending } \\
\text { Byte }\end{array}$ & \\
\hline A. 1 & 1 & $\begin{array}{l}\text { Name of digital } \\
\text { cartographic unit }\end{array}$ & ALPHA & A40 & 1 & 40 & $\begin{array}{l}\text { The name of the digital data } \\
\text { cell followed by the state } \\
\text { two-character designators, } \\
\text { separated by hyphens. }\end{array}$ \\
\hline-- & --- & Filler & -- & -- & 41 & 41 & 1 space \\
\hline A. 1 & 2 & $\begin{array}{l}\text { Date of original } \\
\text { source materials }\end{array}$ & ALPHA & A10 & 42 & 51 & $\begin{array}{l}\text { Year of original source } \\
\text { material, followed by latest } \\
\text { revision date if applicable. } \\
\text { For example, } 1956,1965 .\end{array}$ \\
\hline A. 1 & 3 & Date qualifier & ALPHA & A1 & 52 & 52 & $\begin{array}{l}\text { Qualifier to discriminate } \\
\text { revision date, if present. } \\
\text { ( } P=\text { photorevision, } I=\text { photo- } \\
\text { inspected, L=limited } \\
\text { revision, } D=\text { digital revision) }\end{array}$ \\
\hline A. 1 & 4 & $\begin{array}{l}\text { Scale of original } \\
\text { source material }\end{array}$ & INTEGER*4 & I8 & 53 & 60 & $\begin{array}{l}\text { Scale denominator of source } \\
\text { material; for example, } \\
24000,100000 \text {, or } 2000000 \text {. }\end{array}$ \\
\hline
\end{tabular}

(Data elements 5 through 23 of record A.1 apply to 1:24,000- and 1:100,000-scale files only. For 1:2,000,000-scale data files, bytes $61-144$ of record A.1 are filler.)

\begin{tabular}{|c|c|c|c|c|c|c|c|}
\hline-- & --- & Filler & -- & & 61 & 63 & 3 spaces \\
\hline A. 1 & 5 & $\begin{array}{l}\text { Sectional indicator } \\
\text { (100K files) }\end{array}$ & ALPHA & A3 & 64 & 66 & $\begin{array}{l}\text { Codes } S, F \text {, or } T \text { for size } \\
\text { of section, plus } \\
\text { sequence number. }\end{array}$ \\
\hline
\end{tabular}


APPENDIX A.--Standard DLG Distribution Format (Record Contents)--continued

\begin{tabular}{|c|c|c|c|c|c|c|c|}
\hline $\begin{array}{l}\text { Record } \\
\text { Number }\end{array}$ & $\begin{array}{l}\text { Data } \\
\text { Element }\end{array}$ & Contents & $\begin{array}{c}\text { Type } \\
\text { (Fortion) }\end{array}$ & & Starting & Ending & Comment \\
\hline--- & -- & Filler & -- & --- & 67 & 113 & 47 spaces \\
\hline A. 1 & 6 & $\begin{array}{l}\text { Largest primary } \\
\text { contour interval }\end{array}$ & ALPHA & A4 & 114 & 117 & $\begin{array}{l}\text { Largest primary contour } \\
\text { interval, followed by the } \\
\text { interval unit ( } 1=\text { feet, } \\
2=\text { meters). Present only if } \\
\text { two or more primary intervals } \\
\text { exist. (selected categories) }\end{array}$ \\
\hline A. 1 & 7 & Comma & ALPHA & A1 & 118 & 118 & comma separator \\
\hline A. 1 & 8 & $\begin{array}{l}\text { Largest primary } \\
\text { bathymetric contour } \\
\text { interval }\end{array}$ & ALPHA & A4 & 119 & 122 & $\begin{array}{l}\text { Largest primary bathymetric } \\
\text { interval, followed by the } \\
\text { interval unit ( } 1=\text { feet, } 2= \\
\text { meters, } 3=\text { fathoms). Present } \\
\text { only if two or more primary } \\
\text { intervals exist. (selected } \\
\text { categories) }\end{array}$ \\
\hline--- & -- & Filler & --- & -- & 123 & 123 & 1 space \\
\hline A. 1 & 9 & $\begin{array}{l}\text { Smallest primary } \\
\text { contour interval }\end{array}$ & ALPHA & A4 & 124 & 127 & $\begin{array}{l}\text { Smallest or only primary } \\
\text { interval, followed by the } \\
\text { interval unit as shown } \\
\text { above. (selected categories) }\end{array}$ \\
\hline A. 1 & 10 & Comma & ALPHA & A1 & 128 & 128 & comma separator \\
\hline A. 1 & 11 & $\begin{array}{l}\text { Smallest primary } \\
\text { bathymetric contour } \\
\text { interval }\end{array}$ & ALPHA & A4 & 129 & 132 & $\begin{array}{l}\text { Smallest or only primary } \\
\text { bathymetric interval, fol- } \\
\text { lowed by the interval unit } \\
\text { as shown above. (selected } \\
\text { categories) }\end{array}$ \\
\hline
\end{tabular}


APPENDIX A.--Standard DLG Distribution Format (Record Contents)--continued

Logical Record Type A--continued

\begin{tabular}{|c|c|c|c|c|c|c|c|}
\hline $\begin{array}{l}\text { Record } \\
\text { Number }\end{array}$ & $\begin{array}{l}\text { Data } \\
\text { Element }\end{array}$ & Contents & $\begin{array}{c}\text { Type } \\
\text { (Fortran Notation) }\end{array}$ & Format & $\begin{array}{l}\text { Starting } \\
\text { Byte }\end{array}$ & $\begin{array}{l}\text { Ending } \\
\text { Byte }\end{array}$ & Comment \\
\hline A. 1 & $12-14$ & Coded flags & ALPHA & A1 & 133 & 135 & 3 flags for future use \\
\hline A. 1 & 15 & Coded flag & ALPHA & A1 & 136 & 136 & Database coded edge flag \\
\hline A. 1 & 16 & EDGEWS & ALPHA & A1 & 137 & 137 & $\begin{array}{l}\text { Status flag for west edge, } \\
\text { values are: } b=\text { unchecked, } \\
0=\text { passed, } 1=\text { alignment } \\
\text { discontinuity, } 2 \text { = attribute } \\
\text { discontinuity, } 3 \text { = attribute } \\
\text { and alignment discontinuity. }\end{array}$ \\
\hline A. 1 & 17 & EDGEWR & ALPHA & $\mathrm{A} 1$ & 138 & 138 & $\begin{array}{l}\text { Reason for EDGEWS, values } \\
\text { are: } b=\text { no problem, } 4= \\
\text { adjacent data do not exist } \\
5=\text { adjacent data unavail- } \\
\text { able, } 6=\text { graphic discon- } \\
\text { tinuity, } 7=\text { attribute mis- } \\
\text { match valid, } 8=\text { paneling } \\
\text { unauthorized }\end{array}$ \\
\hline A. 1 & 18 & EDGENS & ALPHA & A1 & 139 & 139 & $\begin{array}{l}\text { Status flag for north edge, } \\
\text { values }=b, 0,1,2 \text {, or } 3 \text { as } \\
\text { above. }\end{array}$ \\
\hline A. 1 & 19 & EDGENR & ALPHA & A1 & 140 & 140 & $\begin{array}{l}\text { Reason for EDGENS, values } \\
\text { are } b, 4,5,6,7 \text {, or } 8 \text { as above. }\end{array}$ \\
\hline A. 1 & 20 & EDGEES & ALPHA & A1 & 141 & 141 & $\begin{array}{l}\text { Status flag for east edge. } \\
\text { Values are } b, 0,1,2 \text {, or } 3 \\
\text { as above. }\end{array}$ \\
\hline A. 1 & 21 & EDGEER & ALPHA & A1 & 142 & 142 & $\begin{array}{l}\text { Reason for EDGEES, values } \\
\text { are } b, 4,5,6,7 \text { or } 8 \text { as above. }\end{array}$ \\
\hline
\end{tabular}


APPENDIX A.--Standard DLG Distribution Format (Record Contents)--continued

\begin{tabular}{|c|c|c|c|c|c|c|c|}
\hline \multirow{3}{*}{$\begin{array}{l}\text { Record } \\
\text { Number }\end{array}$} & \multicolumn{7}{|c|}{ Logical Record Type A--continued } \\
\hline & \multicolumn{4}{|l|}{ Data } & \multirow{2}{*}{$\begin{array}{l}\text { Starting } \\
\text { Byte }\end{array}$} & \multirow{2}{*}{$\begin{array}{l}\text { Ending } \\
\text { Byte }\end{array}$} & \multirow[b]{2}{*}{ Comment } \\
\hline & Element & Contents & tran Notation) & Format & & & \\
\hline A. 1 & 22 & EDGESS & ALPHA & A1 & 143 & 143 & $\begin{array}{l}\text { Status flag for south edge, } \\
\text { values are } b, 0,1,2 \text {, or } 3 \\
\text { as above. }\end{array}$ \\
\hline A. 1 & 23 & EDGESR & ALPHA & $\mathrm{A} 1$ & 144 & 144 & $\begin{array}{l}\text { Reason for EDGESS, values are } \\
b, 4,5,6,7 \text { or } 8 \text {. }\end{array}$ \\
\hline A. 2 & 1 & DLG level code & INTEGER*2 & I6 & 1 & 6 & Code $=3$, DLG -3 \\
\hline A. 2 & 2 & $\begin{array}{l}\text { Code defining } \\
\text { ground planimetric } \\
\text { reference system }\end{array}$ & INTEGER*2 & I6 & 7 & 12 & $\begin{array}{l}\text { Code }=1 \text {, UTM }(24 \mathrm{~K} \text { and } 100 \mathrm{~K}) \\
\text { Code }=3 \text {, Albers Conical Equal } \\
\text { Area (2M) }\end{array}$ \\
\hline A. 2 & 3 & $\begin{array}{l}\text { Code defining zone in } \\
\text { ground planimetric } \\
\text { reference system }\end{array}$ & INTEGER*2 & I6 & 13 & 18 & $\begin{array}{l}\text { Code for appropriate UTM zone } \\
\text { ( } 24 \mathrm{~K} \text { and } 100 \mathrm{~K} \text { files) } \\
\text { Code }=9999 \text { ( } 2 \mathrm{M} \text { files) }\end{array}$ \\
\hline A. 2 & 4 & $\begin{array}{l}\text { Map projection } \\
\text { parameters }\end{array}$ & REAL *8 & $5 \mathrm{D} 24.15$ & 19 & 138 & $\begin{array}{l}\text { This field contains the first } \\
5 \text { of } 15 \text { map projection para- } \\
\text { meters (see Appendix 2-4). }\end{array}$ \\
\hline-- & --- & Filler & -- & -- & 139 & 144 & 6 spaces \\
\hline A. 3 & 1 & $\begin{array}{l}\text { Map projection } \\
\text { parameters }\end{array}$ & REAL*8 & $6 \mathrm{D} 24.15$ & 1 & 144 & $\begin{array}{l}\text { This record contains } \\
\text { projection parameters } 6 \text { thru } \\
11 \text { (see Appendix 2-4). }\end{array}$ \\
\hline A. 4 & 1 & $\begin{array}{l}\text { Map projection } \\
\text { parameters }\end{array}$ & REAL $\star 8$ & $4 \mathrm{D} 24.15$ & 1 & 96 & $\begin{array}{l}\text { This field contains the last } \\
4 \text { projection parameters } \\
\text { (see Appendix } 2-4 \text { ). }\end{array}$ \\
\hline A. 4 & 2 & $\begin{array}{l}\text { Code defining units of } \\
\text { measure for ground } \\
\text { planimetric coordinates } \\
\text { throughout the file }\end{array}$ & INTEGER*2 & I6 & 97 & 102 & Code $=2$, meters \\
\hline
\end{tabular}


APPENDIX A.--Standard DLG Distribution Format (Record Contents)--continued

Logical Record Type A--continued

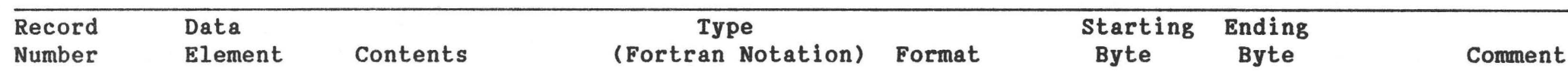

Resolution

REAL*8

D24.15

103

INTEGER*2

I6

acy code of

A. 4

A. 4

Number $(n)$ of sides

in the polygon which

defines the coverage

of the cell

A. 5

Filler

A $(4,2)$ array contain-

ing geographic

coordinates of the

registration points

for the DLG. In

quadrangle-based

mapping, these points

form a geographic square/

rectangle which contain

the domain of the DLG.
INTEGER*2 I6

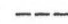

REAL * 8

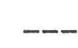

$3(2 \mathrm{D} 24.15)$

2D24. 15
126

The true ground distance corresponding to one unit $(0.001$ inch at map scale) in the file internal reference system.

\begin{tabular}{|c|c|c|}
\hline Scale & Resolut & ion \\
\hline $1 \overline{1: 24,000}$ & 0.61 & M \\
\hline $1: 25,000$ & 0.635 & $\mathbf{M}$ \\
\hline $1: 48,000$ & 1.22 & $\mathbf{M}$ \\
\hline $1: 62,500$ & 1.587 & $\mathbf{M}$ \\
\hline $1: 63,360$ & 1.61 & M \\
\hline $1: 100,000$ & 2.54 & $\mathbf{M}$ \\
\hline $1: 250,000$ & 6.35 & $\mathbf{M}$ \\
\hline $1: 2,000,000$ & 50.80 & $\mathbf{M}$ \\
\hline
\end{tabular}

$1: 2,000,000$

132

Code $=0$, unknown accuracy

$\mathrm{n}=4$

6 spaces

144

The four registration points usually coincide with an area defined by one of the standard map formats of

the National Mapping Program. Coordinates are in geographic

longitude and latitude in units of degrees and decimal degrees and are expressed in the order: $\mathrm{NW}, \mathrm{NE}, \mathrm{SE}$. 
APPENDIX A.--Standard DLG Distribution Format (Record Contents)--continued

Logical Record Type B

\begin{tabular}{|c|c|c|c|c|c|c|c|}
\hline \multirow{2}{*}{$\begin{array}{l}\text { Record } \\
\text { Number }\end{array}$} & \multirow{2}{*}{$\begin{array}{l}\text { Data } \\
\text { Element }\end{array}$} & \multicolumn{3}{|c|}{ Type } & \multirow{2}{*}{$\begin{array}{l}\text { Starting } \\
\text { Byte }\end{array}$} & \multirow{2}{*}{$\begin{array}{l}\text { Ending } \\
\text { Byte }\end{array}$} & \multirow[b]{2}{*}{ Comment } \\
\hline & & Contents & ran Notation) & Format & & & \\
\hline B. 1 & 1 & $\begin{array}{l}\text { Parameters (A1, A2, } \\
\text { A3, A4) of file- } \\
\text { to-ground projection } \\
\text { transformation; the } \\
\text { exp1icit form of the } \\
\text { transformation is: } \\
X=A 1 x+A 2 y+A 3 \\
Y=A 1 y-A 2 x+A 4 \\
\text { where: } \\
X, y \text { are coordinates in } \\
\text { file internal reference } \\
\text { system; } X, Y \text { are coor- } \\
\text { dinates in map projec- } \\
\text { tion reference system }\end{array}$ & REAL $\star 8$ & $4 \mathrm{D} 24.15$ & 1 & 96 & $\begin{array}{l}X, Y \text { coordinates resulting } \\
\text { from this transformation } \\
\text { will be in ground units in } \\
\text { the appropriate projection } \\
\text { defined by the data elements } \\
\text { in records } A .2 \text { through } A .4 \text {. }\end{array}$ \\
\hline B. 1 & 2 & $\begin{array}{l}\text { Number (m) of regis- } \\
\text { tration points }\end{array}$ & INTEGER*2 & I6 & 97 & 102 & $\mathrm{~m}=4$ \\
\hline--- & -- & Filler & -- & -- & 103 & 144 & 42 spaces \\
\hline
\end{tabular}


APPENDIX A.--Standard DLG Distribution Format (Record Contents)--continued

Logical Record Type B--continued

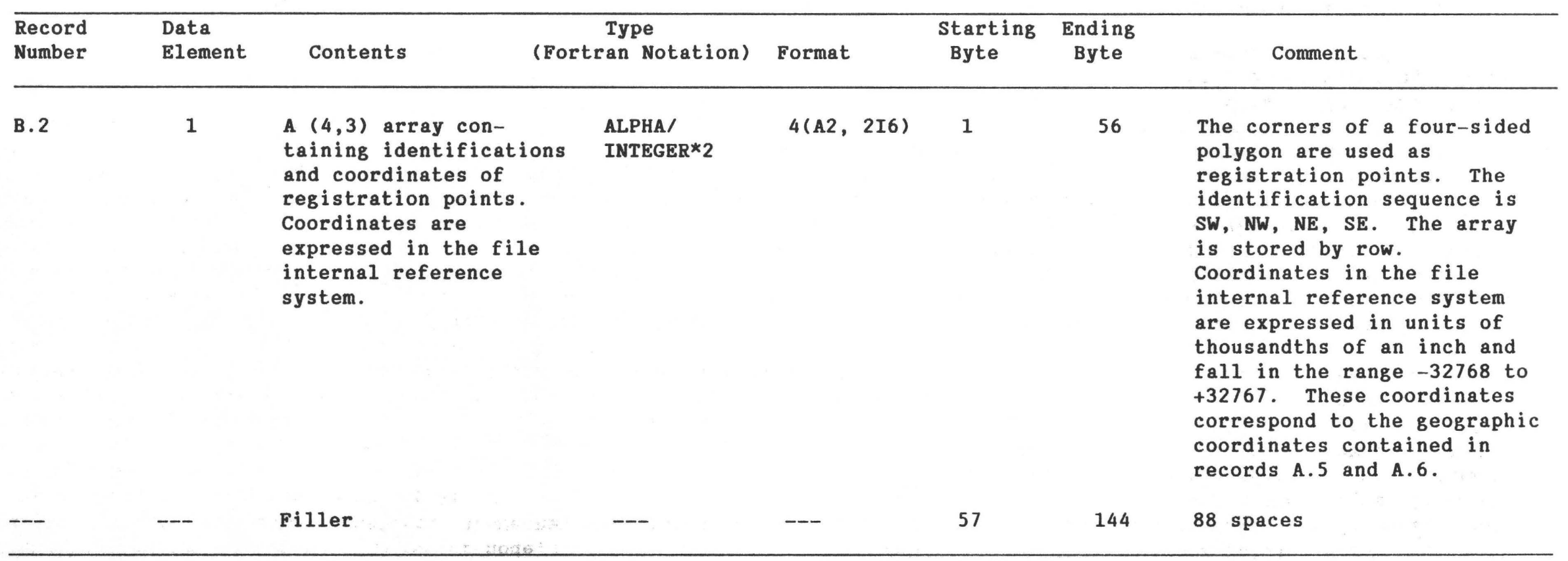


APPENDIX A.--Standard DLG Distribution Format (Record Contents)--continued

Logical Record Type C

\begin{tabular}{|c|c|c|c|c|c|c|c|}
\hline $\begin{array}{l}\text { Record } \\
\text { Number }\end{array}$ & $\begin{array}{l}\text { Data } \\
\text { Element }\end{array}$ & Contents & $\begin{array}{l}\text { Type } \\
\text { tran Notation) }\end{array}$ & Format & $\begin{array}{l}\text { Starting } \\
\text { Byte }\end{array}$ & $\begin{array}{l}\text { Ending } \\
\text { Byte }\end{array}$ & Comment \\
\hline C. 1 & 1 & $\begin{array}{l}\text { Number }(q) \text { of } \\
\text { categories in } \\
\text { the DLG file }\end{array}$ & INTEGER*4 & I6 & 1 & 6 & $q=1$ \\
\hline$-\cdots$ & -- & Filler & --- & --- & 7 & 144 & 138 spaces \\
\hline $\begin{array}{l}\text { C. } 2^{1} \\
\text { to C.N }\end{array}$ & 1 & $\begin{array}{l}\text { A }(q, 7) \text { array contain- } \\
\text { ing category name as } \\
\text { well as maximum and } \\
\text { actual number of node, } \\
\text { area, and line elements } \\
\text { in the category }\end{array}$ & $\begin{array}{l}\text { ALPHA/ } \\
\text { INTEGER*2 }\end{array}$ & $q(A 20,6 I 6)$ & $\begin{array}{l}1 \\
(57\end{array}$ & $\begin{array}{c}56 \\
112)\end{array}$ & $\begin{array}{l}\text { This array is stored by } \\
\text { row. The first element is } \\
\text { the category name consisting } \\
\text { of } 20 \text { alphanumeric char- } \\
\text { acters, the first four of } \\
\text { which are unique. Elements } 2 \\
\text { and } 3 \text { contain the maximum } \\
\text { and actual number of nodes } \\
\text { in the category, elements } 4 \\
\text { and } 5 \text { the maximum and actual } \\
\text { number of areas, and elements } \\
6 \text { and } 7 \text { the maximum and } \\
\text { actual number of line } \\
\text { segments. (Note: for } 24 \mathrm{~K} \text { and } \\
\text { look files, the maximum } \\
\text { number of nodes or areas in } \\
\text { a category is } 25,960 \text { and the } \\
\text { maximum number of } 1 \text { ines is } \\
25,938 \text {. For } 2 \mathrm{M} \text { files, the } \\
\text { maximum number of any } \\
\text { element type within a cate- } \\
\text { gory is } 4,770 \text {. This field } \\
\text { is used only during initial } \\
\text { processing of data. }\end{array}$ \\
\hline--- & -- & Filler & -- & -- & -- & 144 & 32 or 88 spaces \\
\hline
\end{tabular}

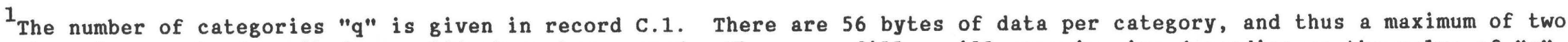

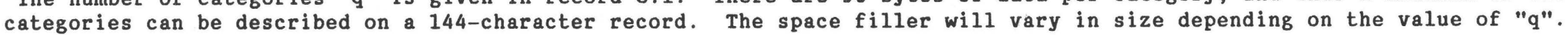

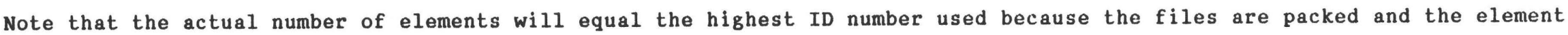
numbers are compressed. 
APPENDIX A.--Standard DLG Distribution Format (Record Contents)--continued

Logical Record Type D

\begin{tabular}{|c|c|c|c|c|c|c|c|}
\hline $\begin{array}{l}\text { Record } \\
\text { Number }\end{array}$ & $\begin{array}{l}\text { Data } \\
\text { Element }\end{array}$ & Contents & $\begin{array}{l}\text { Type } \\
\text { ran Notation) }\end{array}$ & Format & $\begin{array}{l}\text { Starting } \\
\text { Byte }\end{array}$ & $\begin{array}{l}\text { Ending } \\
\text { Byte }\end{array}$ & Comment \\
\hline D. 1 & 1 & $\begin{array}{l}\text { Type of element } \\
\text { code }\end{array}$ & ALPHA & A2 & 1 & 2 & $\begin{array}{r}\text { Code }={ }^{\prime} \mathrm{Nb} \text { ' for Node element, } \\
{ }^{\prime} \mathrm{Ab} \text { ' for Area element. }\end{array}$ \\
\hline D. 1 & 2 & $\begin{array}{l}\text { Element's internal } \\
\text { identification number }\end{array}$ & INTEGER*2 & I6 & 3 & 8 & $\begin{array}{l}\text { Number is positive and seq- } \\
\text { uential from } 1-n \text { within each } \\
\text { element type. }\end{array}$ \\
\hline D. 1 & 3 & $\begin{array}{l}X, Y \text { file coordinate } \\
\text { of node point or repre- } \\
\text { sentative point for the } \\
\text { area element }\end{array}$ & INTEGER*2 & $2 I 6$ & 9 & 20 & $\begin{array}{l}\text { The representative area } \\
\text { point is usually, but not } \\
\text { always, contained within the } \\
\text { area it represents. }\end{array}$ \\
\hline D. 1 & 4 & $\begin{array}{l}\text { Number }(t) \text { of attri- } \\
\text { bute codes which are } \\
\text { attached to the node } \\
\text { or area element }(t>=0)\end{array}$ & INTEGER*2 & I6 & 21 & 26 & $\begin{array}{l}\text { Absence of attribute codes } \\
\text { is indicated by } t=0 \text {. }\end{array}$ \\
\hline D. 1 & 5 & $\begin{array}{l}\text { Number }(k) \text { of pairs of } \\
\text { text characters which are } \\
\text { attached to the node or } \\
\text { area element }(k>=0)\end{array}$ & INTEGER*2 & I6 & 27 & 32 & $k=0$. Not current $1 \mathrm{y}$ used. \\
\hline-- & -- & Filler & -- & -- & 33 & 144 & 112 spaces \\
\hline D. 2 & 1 & $\begin{array}{l}\text { Code indicating a } \\
\text { line segment graph } \\
\text { element }\end{array}$ & ALPHA & A2 & 1 & 2 & Code $=^{\prime} L b^{\prime}$ for line segment. \\
\hline D. 2 & 2 & $\begin{array}{l}\text { Line segment's internal } \\
\text { identification number }\end{array}$ & INTEGER*2 & I6 & 3 & 8 & $\begin{array}{l}\text { Number is positive and seq- } \\
\text { uential from } 1-n \text { within each } \\
\text { category and element type. }\end{array}$ \\
\hline
\end{tabular}


APPENDIX A.--Standard DLG Distribution Format (Record Contents)--continued

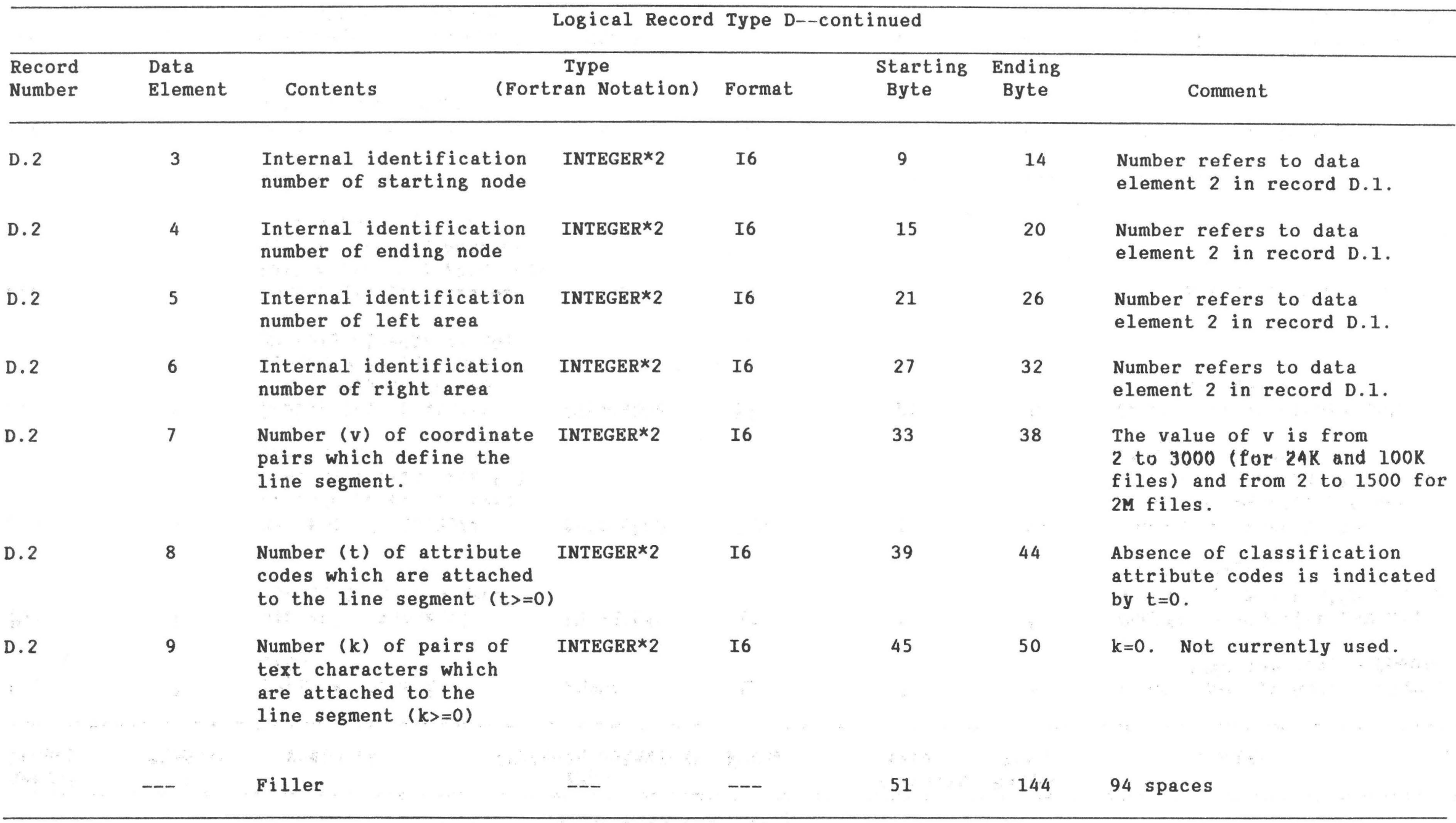


APPENDIX A.--Standard DLG Distribution Format (Record Contents)--continued

\section{Logical Record Type E}

\begin{tabular}{|c|c|c|c|c|c|c|c|}
\hline \multirow{2}{*}{$\begin{array}{l}\text { Record } \\
\text { Number }\end{array}$} & \multirow{2}{*}{$\begin{array}{l}\text { Data } \\
\text { Element }\end{array}$} & \multicolumn{3}{|c|}{ Type } & \multirow{2}{*}{$\begin{array}{l}\text { Starting } \\
\text { Byte }\end{array}$} & \multirow{2}{*}{$\begin{array}{l}\text { Ending } \\
\text { Byte }\end{array}$} & \multirow[b]{2}{*}{ Comment } \\
\hline & & Contents & (an Notation) & Format & & & \\
\hline $\begin{array}{l}\text { E. } 1 \text { to } \\
\text { E. n }\end{array}$ & 1 & $\begin{array}{l}\text { A }(v, 2) \text { array contain- } \\
\text { ing an ordered sequence } \\
\text { of coordinate pairs which } \\
\text { define the image presen- } \\
\text { tation of a line element }\end{array}$ & INTEGER*2 & $v(2 I 6)$ & 1 & & $\begin{array}{l}\text { Coordinates are expressed } \\
\text { in internal file reference } \\
\text { system, in units of } \\
\text { thousandths of an inch. } \\
\text { The array is stored by row. }\end{array}$ \\
\hline-- & --- & Filler & $\cdot---$ & --- & --- & 144 & 0 to 132 spaces \\
\hline
\end{tabular}

2 The number of coordinate pairs, "v", is given in record D.2. There will be v(2I6) coordinate pairs of which a maximum of 12 pairs will fit on a 144-character ASCII record. The space filler will vary in size depending on the value of "v." If " $v$ " is an integer multiple of 12 , there will be no spaces as filler at the end of the record. 
APPENDIX A.--Standard DLG Distribution Format (Record Contents)--continued

\begin{tabular}{|c|c|c|c|c|c|c|c|}
\hline \multirow{2}{*}{$\begin{array}{l}\text { Record } \\
\text { Number }\end{array}$} & \multirow{2}{*}{$\begin{array}{l}\text { Data } \\
\text { Element }\end{array}$} & \multicolumn{3}{|c|}{ Type } & \multirow{2}{*}{$\begin{array}{l}\text { Starting } \\
\text { Byte }\end{array}$} & \multirow{2}{*}{$\begin{array}{c}\text { Ending } \\
\text { Byte }\end{array}$} & \multirow[b]{2}{*}{ Comment } \\
\hline & & Contents & ran Notation) & Format & & & \\
\hline $\begin{array}{l}\mathrm{F} \cdot 1^{3} \\
\text { to } \mathrm{F} \cdot \mathrm{n}\end{array}$ & 1 & $\begin{array}{l}\text { A }(t, 2) \text { array containing } \\
\text { major and minor attribute } \\
\text { codes for a graph element }\end{array}$ & INTEGER* 2 & $t(2 I 6)$ & 1 & & $\begin{array}{l}\text { The array is stored by row } \\
\text { with the first column con- } \\
\text { taining the major attribute } \\
\text { code, and the second column } \\
\text { containing the minor } \\
\text { attribute code. }\end{array}$ \\
\hline--- & --- & Filler & -- & -- & -- & 144 & 0 to 132 spaces \\
\hline
\end{tabular}

${ }^{3}$ The number of feature (attribute) codes, "t" is given in the D.1 and D.2 records. The $F$ record is an array of $t(2 I 6)$

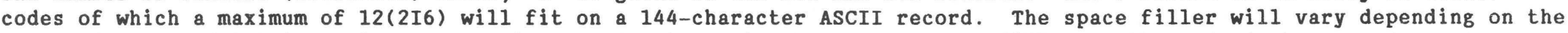
value of "t". If " $t$ " is an integer multiple of 12 there will be no spaces as filler at the end of the record. 


\section{APPENDIX B.--Optional DLG Distribution Format} (Record Contents)

In the optional DLG distribution format, topological linkages can be explicitly encoded for node and area elements as well as for line elements. The files are physically comprised of ASCII characters organized into fixed-length logical records of 80 characters (bytes). Bytes 1-72 of each record contain DLG data, and bytes 73-80 may be blank or contain a record sequence number.

The record types used in the optional DLG distribution format may be categorized as header and data records.

The following are considered header records:

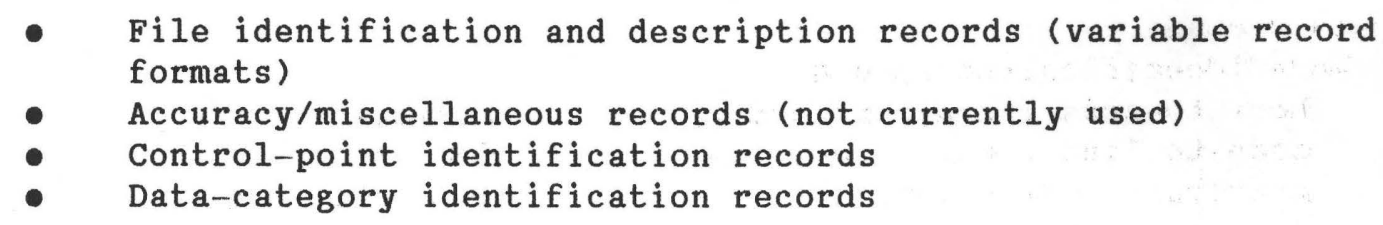

The following are considered data records:

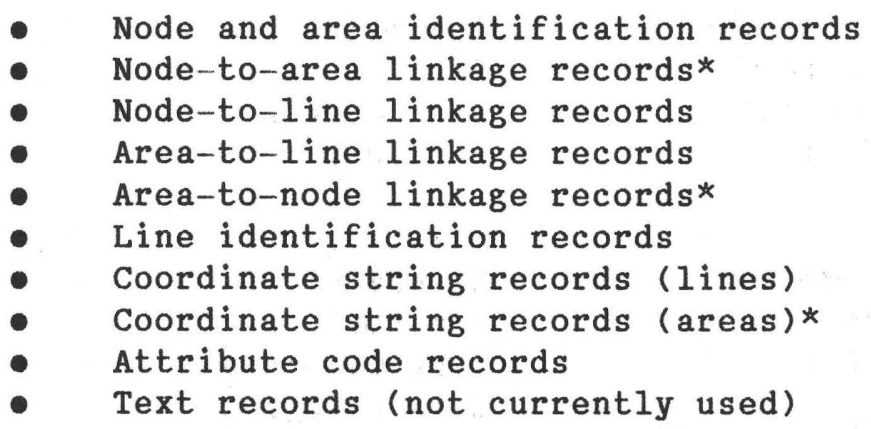

*Data distributed in optional format from the NDCDB will not contain these data records. 
The actual sequence of records in an optional distribution format DLG file is as follows:

1. Header records

Ten file identification and description records

Accuracy records (not currently used)

Control point identification records (one per control-point)

Data category identification records (one per data category in the file)

2. Data records

$\begin{array}{ll}\text { Node identification record } & \\ \text { Node-to-area linkage record(s)* } & \begin{array}{l}\text { Repeated } \\ \text { for each } \\ \text { node-to-line linkage record(s) } \\ \text { nttribute code record(s) } \\ \text { Text record(s) }\end{array} \\ \text { data category } \\ \text { Area identification record } & \\ \text { Area-to-node linkage record(s)* } & \text { Repeated } \\ \text { Area-to-line linkage record(s) } & \text { for each } \\ \text { Coordinate string record(s)* } & \text { area within a } \\ \text { Attribute code record(s) } & \text { data category } \\ \text { Text record(s) } & \\ \text { Line identification record } & \\ \text { Coordinate string record(s) } & \text { Repeated } \\ \text { Attribute code record(s) } & \text { for each } \\ \text { Text record(s) } & \text { line within a } \\ \end{array}$

*Data distributed in optional format from the NDCDB will not contain these records.

Descriptions of the contents of the various types of records in an optional distribution format DLG are contained in the following tables. 
APPENDIX B.--Optional DLG Distribution Format (Record Contents)--continued

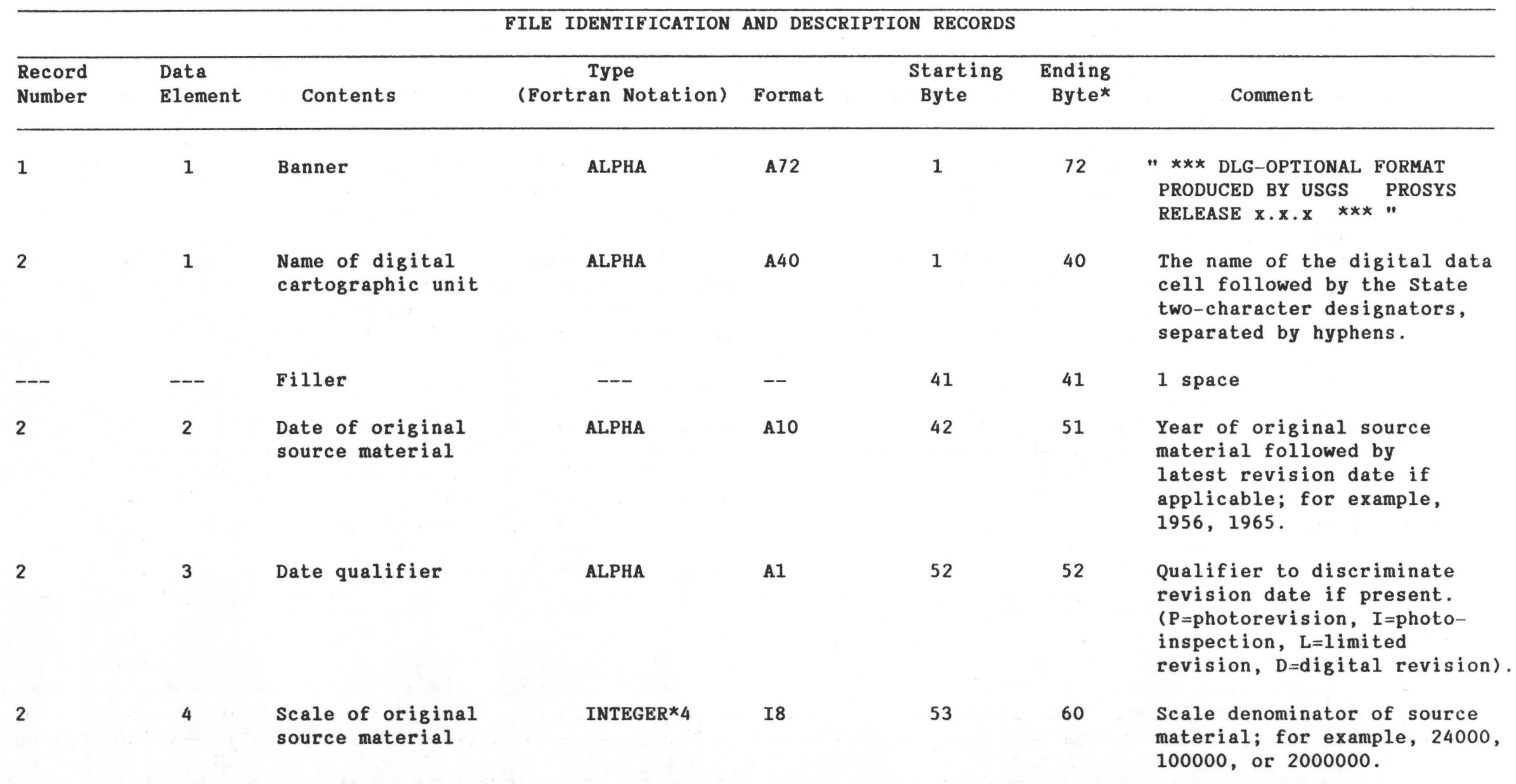

(Record 2, data element 5 and Record 3, data elements 1 through 18 apply to $24 \mathrm{~K}$ and 100K data files only. These fields contain filler in $2 M$ data files.)

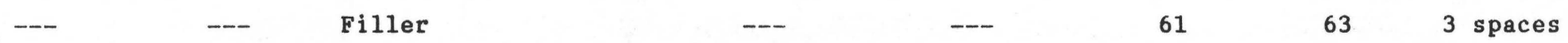

*The logical record length for the optional distribution format is 80 bytes, with 8 spaces of blank fill in bytes $73-80$ of each record which may be used for a record sequence number. 
APPENDIX B.--Optional DLG Distribution Format (Record Contents)--continued

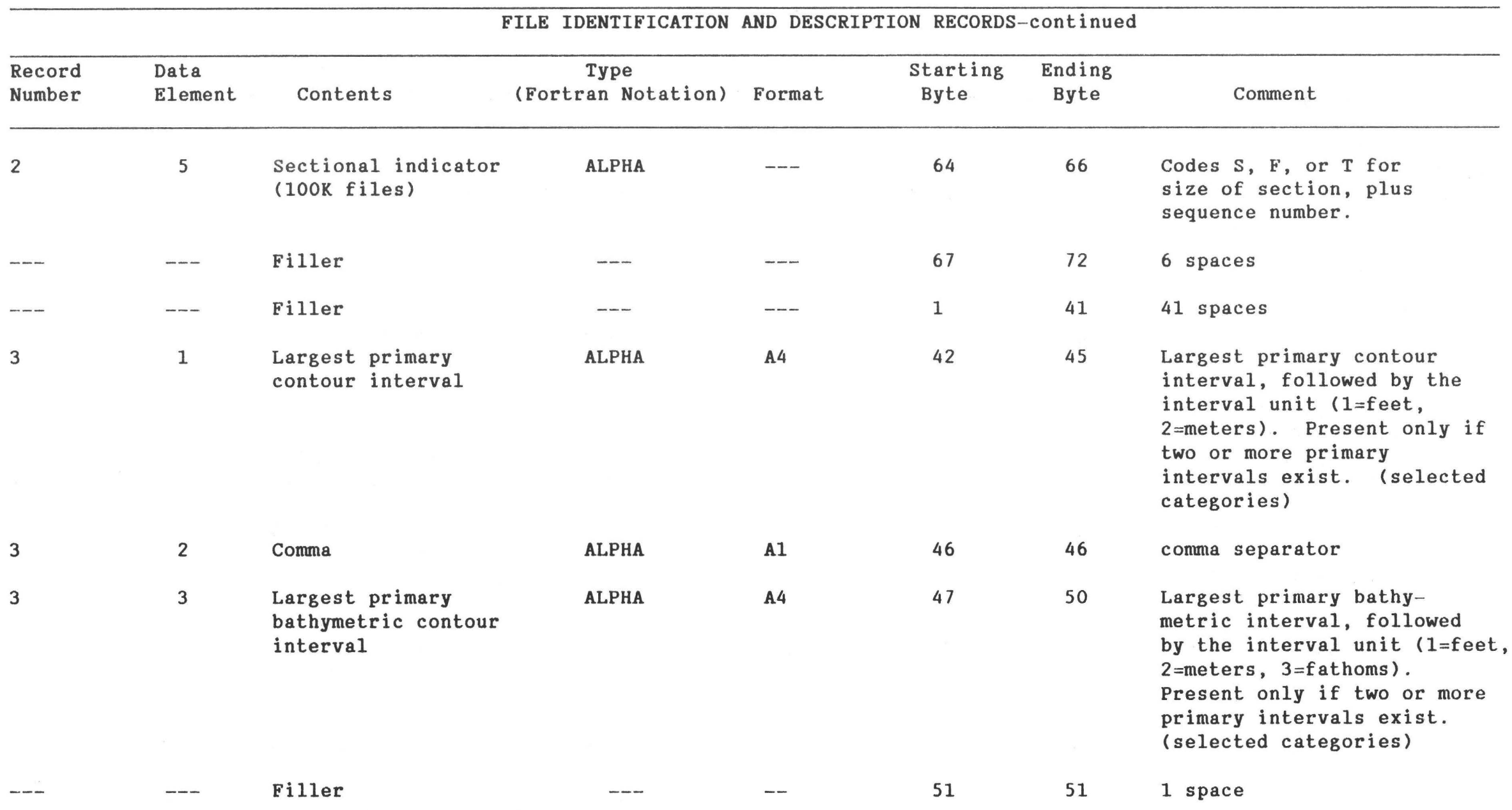


APPENDIX B.--Optional DLG Distribution Format (Record Contents)--continued

FILE IDENTIFICATION AND DESCRIPTION RECORDS

\begin{tabular}{|c|c|c|c|c|c|c|c|}
\hline \multirow{2}{*}{$\begin{array}{l}\text { Record } \\
\text { Number }\end{array}$} & \multicolumn{2}{|l|}{ Data } & \multicolumn{2}{|l|}{ Type } & \multirow{2}{*}{$\begin{array}{l}\text { Starting } \\
\text { Byte }\end{array}$} & \multirow{2}{*}{$\begin{array}{c}\text { Ending } \\
\text { Byte }\end{array}$} & \multirow[b]{2}{*}{ Comment } \\
\hline & Element & Contents & (Fortran Notation) & Format & & & \\
\hline
\end{tabular}

3

4 Smallest primary

ALPHA

A4

52

55

Smallest or only primary contour interval

(2)

$\begin{array}{ll}55 \\ 67 & 56\end{array}$

contour interval, followed by the interval unit as described above (selected categories).

3

5 Comma

3

6 Smallest primary

\section{ALPHA}

A1

bathymetric contour

ALPHA

A4

comma separator

interval

के 3

7-9 Coded Flags

10 Coded Flag

ALPHA

A1

ALPHA

A1

61

63

3

11

EDGEWS

ALPHA

A1

65

65

65

Smallest or only primary

bathymetric contour interval, followed by the interval unit as described above (selected categories).

3 flags for future use

Database coded edge flag for internal NMD use.

Status flag for west edge, values are: $b=$ unchecked, $0=$ passed, $1=a 1$ ignment discontinuity, 2=attribute discontinuity, 3 =attribute and alignment discontinuity.

ALPHA

A1

66

66

Reason for EDGEWS, values are: $b=$ no problem, $4=$ adjacent data do not exist, $5=a d j a c e n t$ data unavailable, $6=$ graphic discontinuity, $7=$ graphic mismatch valid, $8=$ paneling unauthorized. 
APPENDIX B.--Optional DLG Distribution Format (Record Contents)--continued

\begin{tabular}{|c|c|c|c|c|c|c|c|}
\hline \multirow[b]{2}{*}{$\begin{array}{l}\text { Record } \\
\text { Number }\end{array}$} & \multirow[b]{2}{*}{$\begin{array}{l}\text { Data } \\
\text { Element }\end{array}$} & \multicolumn{2}{|r|}{ FILE IDENTIFICATION } & \multicolumn{2}{|c|}{ AND DESCRIPTION RECORDS } & \multirow[b]{2}{*}{$\begin{array}{l}\text { Ending } \\
\text { Byte }\end{array}$} & \multirow[b]{2}{*}{ Comment } \\
\hline & & Contents & $\begin{array}{c}\text { Type } \\
\text { (Fortran Notation) }\end{array}$ & Format & $\begin{array}{l}\text { Starting } \\
\text { Byte }\end{array}$ & & \\
\hline 3 & 13 & EDGENS & ALPHA & A1 & 67 & 67 & $\begin{array}{l}\text { Status flag for north edge, } \\
\text { values are } b, 0,1,2 \text {, or } 3 \text { as } \\
\text { above. }\end{array}$ \\
\hline 3 & 14 & EDGENR & ALPHA & A1 & 68 & 68 & $\begin{array}{l}\text { Reason for EDGENS, values } \\
\text { are } b, 4,5,6,7 \text { or } 8 \text { as above. }\end{array}$ \\
\hline 3 & 15 & EDGEES & ALPHA & A1 & 69 & 69 & $\begin{array}{l}\text { Status flag for east edge, } \\
\text { values are } b, 0,1,2 \text {, or } 3 \\
\text { as above. }\end{array}$ \\
\hline 3 & 16 & EDGEER & ALPHA & A1 & 70 & 70 & $\begin{array}{l}\text { Reason for EDGEES, values } \\
\text { are } b, 4,5,6,7 \text { or } 8 \text { as above. }\end{array}$ \\
\hline 3 & 17 & EDGESS & ALPHA & A1 & 71 & 71 & $\begin{array}{l}\text { Statusflag forsouth edge, } \\
\text { values are } b, 0,1,2 \text {, or } 3 \\
\text { as above. }\end{array}$ \\
\hline 3 & 18 & EDGESR & ALPHA & A1 & 72 & 72 & $\begin{array}{l}\text { Reason for EDGESS, values } \\
\text { are b, } 4,5,6,7 \text { or } 8 \text { as above. }\end{array}$ \\
\hline 4 & 1 & DLG level code & INTEGER $²$ & I6 & 1 & 6 & $\star \quad \operatorname{Code}=3$, DLG -3 \\
\hline 4 & 2 & $\begin{array}{l}\text { Code defining ground } \\
\text { planimetric reference } \\
\text { system }\end{array}$ & INTEGER $²$ & I6 & 7 & 12 & $\begin{array}{l}{ }^{1} \text { Code }=1 \text { UTM }(24 \mathrm{~K} \text { and } 100 \mathrm{~K}) \\
\text { Code=3 Albers Conical Equal } \\
\text { Area ( } 2 M \text { files) }\end{array}$ \\
\hline 4 & 3 & $\begin{array}{l}\text { Code defining zone in } \\
\text { ground planimetric } \\
\text { reference system }\end{array}$ & INTEGER*2 & I6 & 13 & 18 & $\begin{array}{l}*{ }^{1} \text { Code for appropriate UTM } \\
\text { zone (24K or 100K files), } \\
\text { Code }=9999 \text { for } 2 M \text { files }\end{array}$ \\
\hline
\end{tabular}

1 See General Purpose Transformation Package software documentation for additional information.

* Listed values reflect current NMD standard. 
APPENDIX B.--Optional DLG Distribution Format (Record Contents)--continued

FILE IDENTIFICATION AND DESCRIPTION RECORDS

\begin{tabular}{|c|c|c|c|c|c|c|c|}
\hline Record & Data & & Type & & Starting & Ending & \\
\hline Number & Element & Contents & (Fortran Notation) & Format & Byte & Byte & Comment \\
\hline
\end{tabular}

$4 \quad$ Code defining units

INTEGER*2 I6

of measure for ground

planimetric coordinates

throughout the file

$\operatorname{REAL} * 4$

D18.11

INTEGER*2

I6

map transformation

parameters

7

Number of accuracy/

miscellaneous records

8

INTEGER*2 I6

INTEGER $* 2$

I6

control point

649

43

48

42

The true ground distance corresponding to 0.001 inch at map scale.

Scale

$1: 24,000$

$1: 25,000$

$1: 48,000$

$1: 62,500$

$1: 63,360$

$1: 100,000$

$1: 250,000$

Resolutions

$1: 2,000,000 \quad 50.80 \quad M$

$0.61 \mathrm{M}$

$0.635 \mathrm{M}$

$1.22 \mathrm{M}$

$1.587 \mathrm{M}$

$1.61 \mathrm{M}$

$2.54 M$

$6.35 \mathrm{M}$

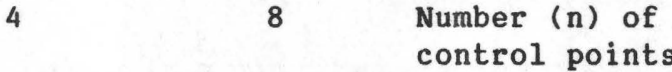

INTER


APPENDIX B.--Optional DLG Distribution Format (Record Contents)--continued

FILE IDENTIFICATION AND DESCRIPTION RECORDS

\begin{tabular}{|c|c|c|c|c|c|c|c|}
\hline $\begin{array}{l}\text { Record } \\
\text { Number }\end{array}$ & $\begin{array}{l}\text { Data } \\
\text { Element }\end{array}$ & Contents & $\begin{array}{l}\text { Type } \\
\text { ran Notation) }\end{array}$ & Format & $\begin{array}{l}\text { Starting } \\
\text { Byte }\end{array}$ & $\begin{array}{l}\text { Ending } \\
\text { Byte }\end{array}$ & Comment \\
\hline 4 & 9 & $\begin{array}{l}\text { Number (q) of categories } \\
\text { in the DLG file }\end{array}$ & INTEGER $R 2$ & I6 & 61 & 66 & $\star q=1$ \\
\hline--- & --- & Filler & --- & --- & 67 & 72 & 6 spaces \\
\hline $5-9$ & 1 & $\begin{array}{l}\text { Projection parameters } \\
\text { for map transformation }\end{array}$ & $\mathrm{REAL} * 8$ & 3D24.15 & 1 & 72 & $\begin{array}{l}\text { Three parameters on each of } \\
5 \text { records (see Appendix 2-4). }\end{array}$ \\
\hline 10 & 1 & $\begin{array}{l}\text { Internal file-to- } \\
\text { map projection } \\
\text { transformation } \\
\text { parameters }\end{array}$ & $\mathrm{REAL} * 4$ & 4D18.11 & 1 & 72 & $\begin{array}{l}\mathrm{X}, \mathrm{Y} \text { coordinates resulting } \\
\text { from this transformation will } \\
\text { be expressed in the appro- } \\
\text { priate ground planimetric } \\
\text { coordinate system. If the } \\
\mathrm{X}, \mathrm{y} \text { coordinates are already } \\
\text { in the ground coordinate } \\
\text { system, the projection para- } \\
\text { meters will be: } \mathrm{A} 1=1.0 \text {, } \\
\mathrm{A} 2=0.0, \mathrm{~A} 3=0.0 \text {, and } \mathrm{A} 4=0.0 \text {. }\end{array}$ \\
\hline
\end{tabular}

* Listed values reflect current NMD standard. 
APPENDIX B.--Optional DLG Distribution Format (Record Contents)--continued

CONTROL POINT IDENTIFICATION RECORDS

\begin{tabular}{|c|c|c|c|c|c|c|c|}
\hline $\begin{array}{l}\text { Record } \\
\text { Number }\end{array}$ & $\begin{array}{l}\text { Data } \\
\text { Element }\end{array}$ & Contents & $\begin{array}{c}\text { Type } \\
\text { (Fortran Notation) }\end{array}$ & Format & $\begin{array}{l}\text { Starting } \\
\text { Byte }\end{array}$ & $\begin{array}{l}\text { Ending } \\
\text { Byte }\end{array}$ & Comment \\
\hline \multirow[t]{6}{*}{$1-n$} & 1 & Control-point label & ALPHA & A6 & 1 & 6 & $\begin{array}{l}\text { "SW," "NW," "NE," or "SE" } \\
\text { for four quadrangle } \\
\text { corners. Field is padded } \\
\text { with trailing blanks. }\end{array}$ \\
\hline & 2 & Latitude & REAL *4 & F12.6 & 7 & 18 & $\begin{array}{l}\text { In degrees and decimal } \\
\text { degrees. }\end{array}$ \\
\hline & 3 & Long itude & REAL *4 & F12.6 & 19 & 30 & $\begin{array}{l}\text { In degrees and decimal } \\
\text { degrees. }\end{array}$ \\
\hline & & Filler & & & 31 & 36 & 6 spaces \\
\hline & 4 & $\mathrm{X}$ coordinate & REAL*4 & F12. 2 & 37 & 48 & $\begin{array}{l}\text { In units in the appropriate } \\
\text { zone of the ground plani- } \\
\text { metric coordinate system. }\end{array}$ \\
\hline & 5 & $\mathrm{Y}$ coordinate & REAL *4 & F12.2 & 49 & 60 & $\begin{array}{l}\text { In units in the appropriate } \\
\text { zone of the ground plani- } \\
\text { metric coordinate system. }\end{array}$ \\
\hline-- & -- & Filler & -- & $-\cdots$ & 61 & 72 & 12 spaces \\
\hline
\end{tabular}


APPENDIX B.--Optional DLG Distribution Format (Record Contents)--continued

DATA CATEGORY IDENTIFICATION RECORDS

\begin{tabular}{|c|c|c|c|c|c|c|c|}
\hline \multirow{2}{*}{$\begin{array}{l}\text { Record } \\
\text { Number }\end{array}$} & \multirow{2}{*}{$\begin{array}{l}\text { Data } \\
\text { Element }\end{array}$} & \multirow[b]{2}{*}{ Contents } & Type & \multirow[b]{2}{*}{ Format } & \multirow{2}{*}{$\begin{array}{l}\text { Starting } \\
\text { Byte }\end{array}$} & \multirow{2}{*}{$\begin{array}{l}\text { Ending } \\
\text { Byte }\end{array}$} & \multirow[b]{2}{*}{ Comment } \\
\hline & & & Fortran Notation) & & & & \\
\hline \multirow[t]{8}{*}{$1-q$} & 1 & Category name & ALPHA & A20 & 1 & 20 & $\begin{array}{l}\text { The first } 4 \text { characters are } \\
\text { unique to USGS/NMD data. }\end{array}$ \\
\hline & 2 & Attribute format codes & INTEGER*2 & 14 & 21 & 24 & $\begin{array}{l}\text { Blank or zero }(0) \text { indicates } \\
\text { default ( } 2 \text { I6) attribute } \\
\text { formatting in major-minor } \\
\text { pairs. }\end{array}$ \\
\hline & 3 & $\begin{array}{l}\text { Highest node } \\
\text { identification number. }\end{array}$ & INTEGER*2 & I6 & 25 & 30 & $\begin{array}{l}\text { Number of nodes referenced } \\
\text { in the file. }\end{array}$ \\
\hline & 4 & $\begin{array}{l}\text { Actual number of } \\
\text { nodes in } \mathrm{file}\end{array}$ & INTEGER*2 & I6 & 31 & 36 & $\begin{array}{l}\text { Only if the DCF is not } \\
\text { packed, and the element } \\
\text { ID numbers not compressed, } \\
\text { will this number be dif- } \\
\text { ferent from data element } 3 \text {. }\end{array}$ \\
\hline & -- & Filler & -- & --- & 37 & 37 & 1 space \\
\hline & 5 & $\begin{array}{l}\text { Presence of node-to- } \\
\text { area linkage records }\end{array}$ & INTEGER*2 & I1 & 38 & 38 & $\begin{array}{l}* 0=\text { node-area list not } \\
\text { included, } 1=\text { node-area } \\
\text { list included. }\end{array}$ \\
\hline & 6 & $\begin{array}{l}\text { Presence of node-to- } \\
\text { line linkage records }\end{array}$ & INTEGER*2 & I1 & 39 & 39 & $\begin{array}{l}0=\text { node- } 1 \text { ine } 1 \text { ist not } \\
\text { included, } * 1=\text { node- } 1 \text { ine } 1 \text { ist } \\
\text { included. }\end{array}$ \\
\hline & -- & Filler & --- & --- & 40 & 40 & 1 zero or space \\
\hline
\end{tabular}

*Values marked are values from data distributed from the NDCDB. 
APPENDIX B.--Optional DLG Distribution Format (Record Contents)--continued

DATA CATEGORY IDENTIFICATION RECORDS--cont inued

\begin{tabular}{|c|c|c|c|c|c|c|c|}
\hline \multirow{2}{*}{$\begin{array}{l}\text { Record } \\
\text { Number }\end{array}$} & \multirow{2}{*}{$\begin{array}{l}\text { Data } \\
\text { Element }\end{array}$} & \multicolumn{3}{|c|}{ Type } & \multirow{2}{*}{$\begin{array}{l}\text { Starting } \\
\text { Byte }\end{array}$} & \multirow{2}{*}{$\begin{array}{c}\text { Ending } \\
\text { Byte }\end{array}$} & \multirow[b]{2}{*}{ Comment } \\
\hline & & Contents & Fortran Notation) & Format & & & \\
\hline \multirow[t]{6}{*}{$1-q$} & 7 & $\begin{array}{l}\text { Highest area ID } \\
\text { number. }\end{array}$ & INTEGER*2 & I6 & 41 & 46 & $\begin{array}{l}\text { Number of areas refer- } \\
\text { enced in the file. }\end{array}$ \\
\hline & 8 & $\begin{array}{l}\text { Actual number of areas } \\
\text { in file }\end{array}$ & INTEGER*2 & I6 & 47 & 52 & $\begin{array}{l}\text { Only if the DCF is not } \\
\text { packed, and the element ID } \\
\text { numbersnotcompressed, } \\
\text { will this number be different } \\
\text { from data element } 7 \text {. }\end{array}$ \\
\hline & -- & Filler & $\cdots$ & --- & 53 & 53 & 1 space \\
\hline & 9 & $\begin{array}{l}\text { Presence of area-to- } \\
\text { node linkage records }\end{array}$ & INTEGER*2 & I1 & 54 & 54 & $\begin{array}{l}* 0=\text { area-node } 1 \text { ist not } \\
\text { included, } 1=\text { area-node } 1 \text { ist } \\
\text { included. }\end{array}$ \\
\hline & 10 & $\begin{array}{l}\text { Presence of area-to- } \\
\text { line linkage records }\end{array}$ & INTEGER*2 & I1 & 55 & 55 & $\begin{array}{l}0=\text { area- } 1 \text { ine list not } \\
\text { included, }{ }^{*} 1=\text { area-line } 1 \text { ist } \\
\text { included. }\end{array}$ \\
\hline & 11 & $\begin{array}{l}\text { Presence of area- } \\
\text { coordinate } 1 \text { ists }\end{array}$ & INTEGER*2 & I1 & 56 & 56 & $\begin{array}{l}\text { *0 =area coordinates not } \\
\text { included, } 1=\text { area coordinates } \\
\text { included }\end{array}$ \\
\hline & 12 & $\begin{array}{l}\text { Highest line } \\
\text { identification number }\end{array}$ & INTEGER*2 & I6 & 57 & 62 & $\begin{array}{l}\text { Number of lines } \\
\text { referenced in the file. }\end{array}$ \\
\hline
\end{tabular}

*Values marked are values for data distributed from the NDCDB. 
APPENDIX B.--Optional DLG Distribution Format (Record Contents)--continued

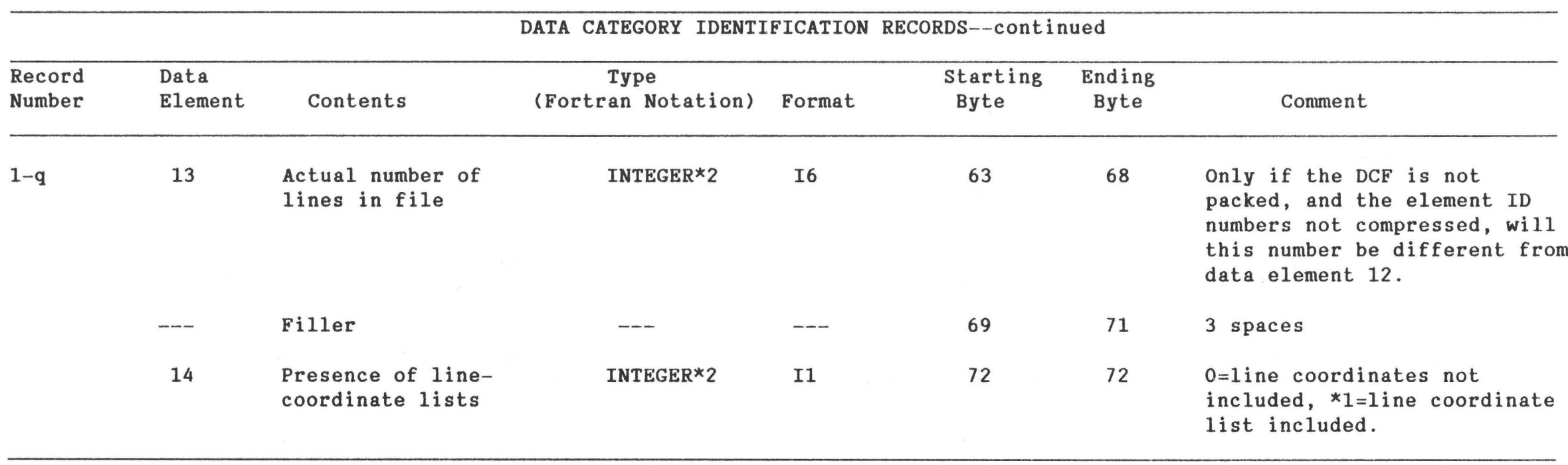

*Values marked are values for data distributed from the NDCDB. 
APPENDIX B.--Optional DLG Distribution Format (Record Contents)--continued

NODE AND AREA IDENTIFICATION RECORDS

\begin{tabular}{|c|c|c|c|c|c|c|c|}
\hline $\begin{array}{l}\text { Record } \\
\text { Number }\end{array}$ & $\begin{array}{l}\text { Data } \\
\text { Element }\end{array}$ & (Fortr & $\begin{array}{l}\text { Type } \\
\text { (an Notation) }\end{array}$ & Format & $\begin{array}{l}\text { Starting } \\
\text { Byte }\end{array}$ & $\begin{array}{c}\text { Ending } \\
\text { Byte }\end{array}$ & Comment \\
\hline & 1 & Record type & ALPHA & A1 & 1 & 1 & "N" or "A" \\
\hline & 2 & $\begin{array}{l}\text { Element internal } \\
\text { ID number }\end{array}$ & INTEGER*2 & I5 & 2 & 6 & $\begin{array}{l}\text { Number is positive and seq- } \\
\text { uential from } 1-n \text { within each } \\
\text { element type, where } n \text { is the } \\
\text { highest element ID number. }\end{array}$ \\
\hline & 3 & $\begin{array}{l}\text { Coordinates of node } \\
\text { point or representative } \\
\text { point for area }\end{array}$ & REAL *4 & $2 \mathrm{~F} 12.2$ & 7 & 30 & $\begin{array}{l}\text { The area point is usually, } \\
\text { but not always within the } \\
\text { polygon it represents. }\end{array}$ \\
\hline & 4 & $\begin{array}{l}\text { Number of elements in } \\
\text { an area list (for nodes), } \\
\text { or a node list (for areas) }\end{array}$ & INTEGER*2 & I6 & 31 & 36 & \\
\hline & 5 & $\begin{array}{l}\text { Number of elements in } \\
\text { line list }\end{array}$ & INTEGER*2 & I6 & 37 & 42 & $\begin{array}{l}\text { Number of line segments that } \\
\text { intersect at the node or, for } \\
\text { areas, line segments plus } \\
\text { number of islands. }\end{array}$ \\
\hline & 6 & $\begin{array}{l}\text { Number of } x, y \text { or } \\
\text { lat-long points in } \\
\text { area-coordinate list }\end{array}$ & INTEGER*2 & I6 & 43 & 48 & $\begin{array}{l}\text { For area records only, } \\
\text { blank for node records. }\end{array}$ \\
\hline & 7 & $\begin{array}{l}\text { Number of attribute } \\
\text { code pairs listed }\end{array}$ & INTEGER 22 & I6 & 49 & 54 & \\
\hline & 8 & $\begin{array}{l}\text { Number of text } \\
\text { characters } 1 \text { isted }\end{array}$ & INTEGER*2 & I6 & 55 & 60 & $\begin{array}{l}\text { Zero }(0) \text {. There are no } \\
\text { text attributes for DLG data. }\end{array}$ \\
\hline & 9 & $\begin{array}{l}\text { Number of islands } \\
\text { within area }\end{array}$ & INTEGER*2 & I6 & 61 & 66 & $\begin{array}{l}\text { For area records only, blank } \\
\text { for node records. }\end{array}$ \\
\hline-- & -- & Filler & -- & -- & 67 & 72 & 6 spaces \\
\hline
\end{tabular}


APPENDIX B.--Optional DLG Distribution Format (Record Contents)--continued

NODE-TO-AREA LINKAGE RECORDS

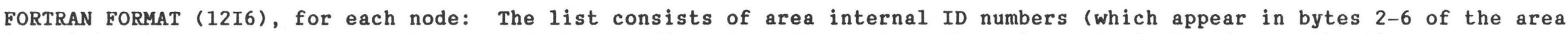
identification records) of all the areas that are adjacent to that node. There is no logical order to the list.

NODE-TO-LINE LINKAGE RECORDS

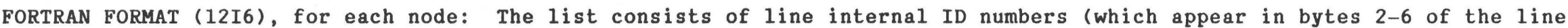

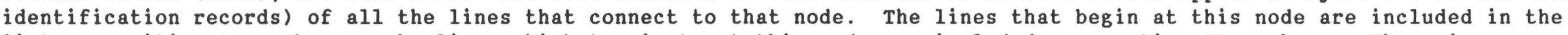
list as positive ID numbers. The lines which terminate at this node are included as negative ID numbers. There is no logical order to the list.

AREA-TO-NODE LINKAGE RECORDS

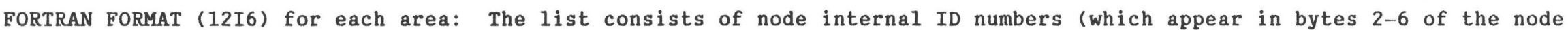

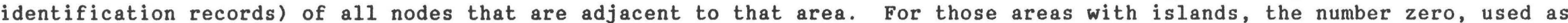

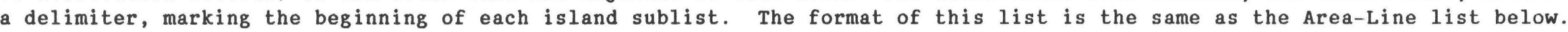

\section{AREA-TO-LINE LINKAGE RECORDS}

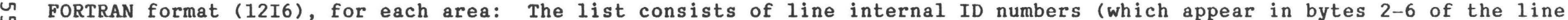

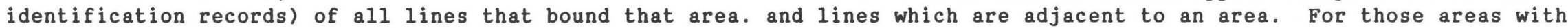

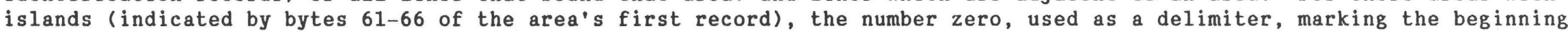
of islands. Lines with this area to the right are included as positive ID numbers. Lines with this area to the left are

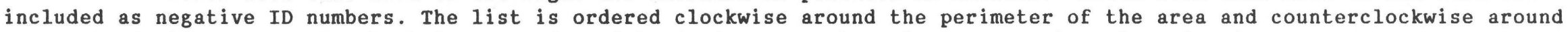
each island, if any (counterclockwise around an island of an area is still a clockwise direction in reference to the area

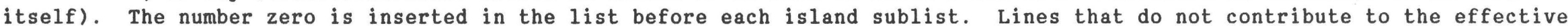
boundary of the area (those having both their area left and area right assigned to the same area) are not considered

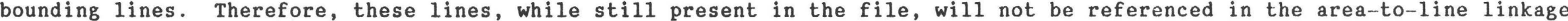
records. 
APPENDIX B.--Optional DLG Distribution Format (Record Contents)--continued

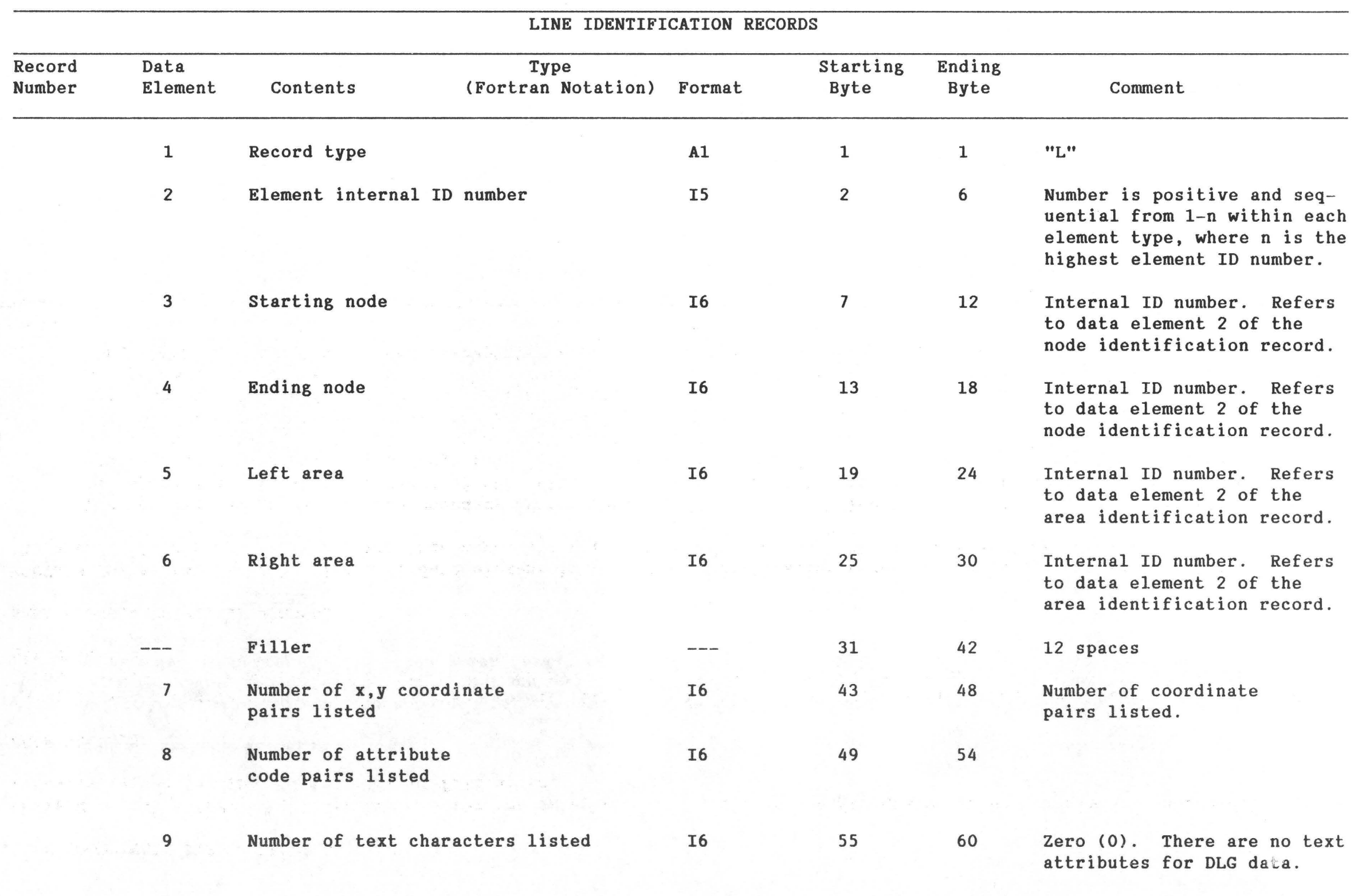




\section{APPENDIX B.--Optional DLG Distribution Format (Record Contents)--continued}

LINE COORDINATE STRING RECORDS

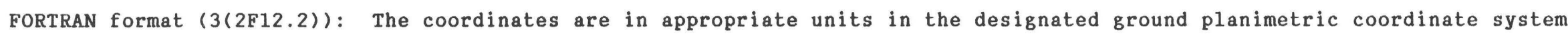
(usually meters in UTM), or in internal file units.

CODE RECORDS

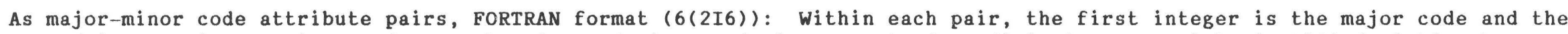
second integer is the minor code. Each major and minor code is a one-to-four-digit integer, right justified within the six-byte field.

AREA COORDINATE STRING RECORDS

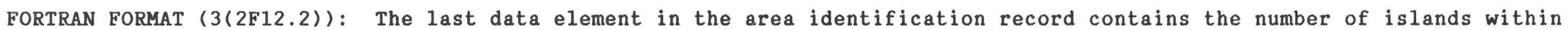
the area. If this number is greater than zero, the following convention applies to the Area Coordinate list:

The coordinates of the outside boundary of the area are listed first. The first coordinate of the outside boundary is repeated to signal the closure of this ring. Next, the coordinates of one of the islands are listed. The first coordinate of this boundary is repeated, again signaling the end of this ring. Next, the first coordinate of the outside boundary is listed as a ring delimiter. This process is repeated until the coordinates of the boundaries of all the islands are listed. The coordinates in this list are ordered so that the area being referenced is always to the right of the boundary described by the sequence of coordinates. Therefore, the list is ordered clockwise around the perimeter of the area and counterclockwise around each island, if any. The common coordinates between adjacent ring lines are only listed once, except for the beginning and ending of a $r i n g$. 


\section{APPENDIX B.--Optional DLG Distribution Format (Record Contents)--continued}

EXAMPLE 1: (A diagram illustrating this example may be found following the text.)

Area line list (for area 41): $10,11,-12,0,14,-15,0,-18,0,-82,-84,21$

Area node 1 ist (for area 41 ): $30,31,32,0,33,34,0,35,0,36,77,76$

Area coordinate list explanation:

- Outside ring coordinates: $(20,50),(40,60),(60,50),(70,40),(60,20),(40,10),(30,10),(20,30),(10,40),(20,50)$ starting point [

L10

- 1st island ring coordinates: $(25,45),(28,39),(34,43),(34,48),(30,50),(25,45),(20,50)$ [$$
\text { L14 }
$$

L11

ring closes itself

L15

- next island ring coordinates: $(30,30),(30,20),(40,20),(40,30),(30,30),(20,50) \quad$ ring delimiter [

L18

- last island ring coordinates: $(50,40),(50,30),(48,22),(58,24),(60,35),(55,45),(50,40),(20,50)$ ring delimiter must be present at end of list if

Note: Since lines 80,85 , and 86 have area 41 as both their area left and area right, they are not considered "boundaries" of area 41. Therefore, they are not used to build the area line list, area node 1 ist, or area coordinate 1 ist for this area.

Complete area coordinate 1 ist:

$(20,50),(40,60),(60,50),(70,40),(60,20),(40,10),(30,10),(20,30),(10,40),(20,50)$,

$(25,45),(28,39),(34,43),(34,48),(30,50),(25,45),(20,50)$,

$(30,30),(30,20),(40,20),(40,30),(30,30),(20,50)$,

$(50,40),(50,30),(48,22),(58,24),(60,35),(55,45),(50,40),(20,50)$ 


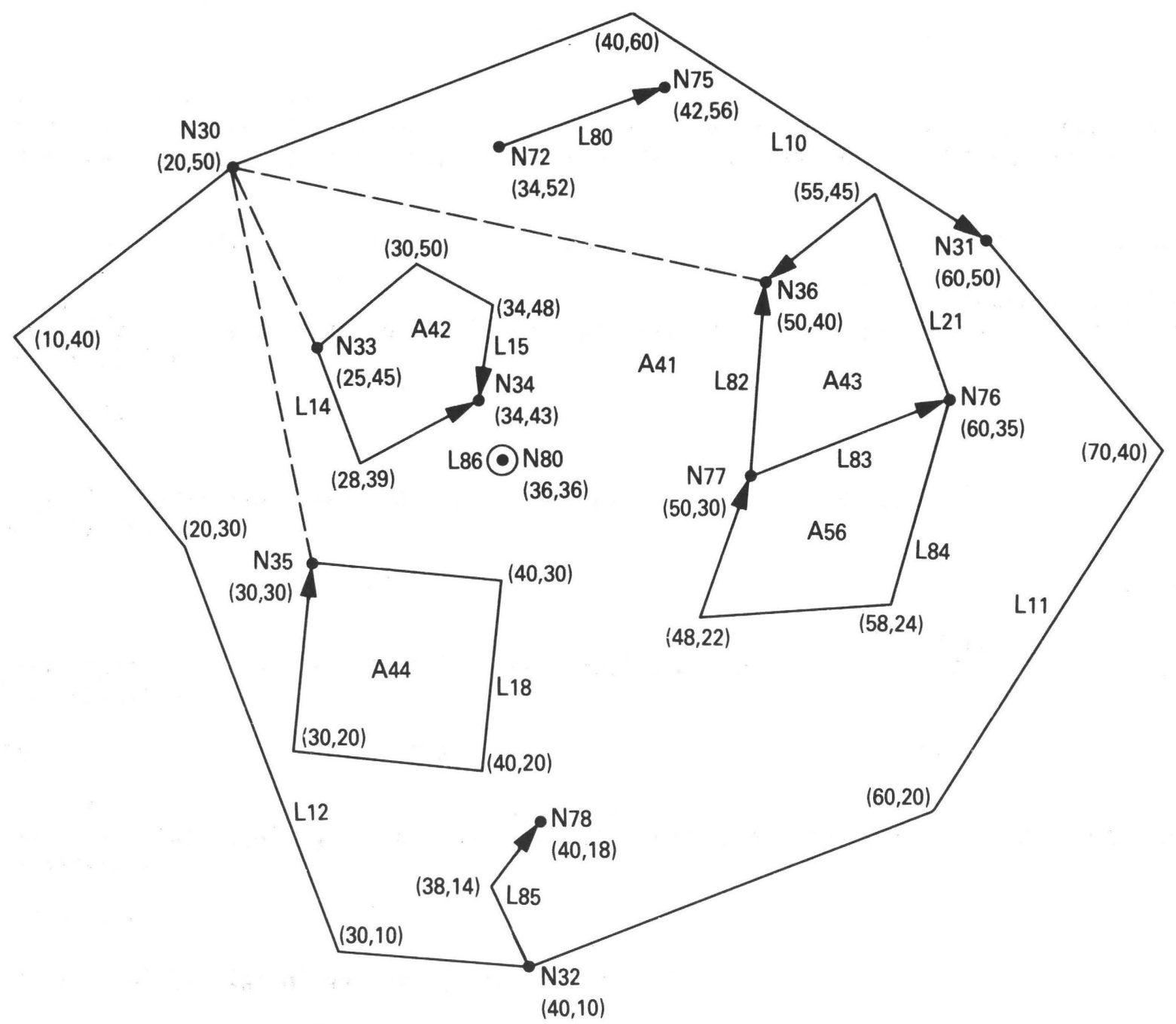

Diagram illustrating Example 1 on previous page. 


\section{APPENDIX C.--Map Projection Parameters \\ Universal Transverse Mercator (UTM)}

The standard and optional DLG distribution formats include 15 fields reserved for map projection parameters. These parameters are typically used as input for a coordinate transformation package such as the USGS General Cartographic Transformation Package (GCTP).

When the ground coordinate system of a DLG is the Universal Transverse Mercator system, as in the case for a11 DLG's digitized from 1:100,000scale maps, only the first two of the 15 parameter fields are used:

1. Longitude of any point in UTM zone.

Normally placed at the

2. Latitude of any point in UTM zone. center of the DLG cell.

3-15. Not used $(=0)$.

A transformation to or from UTM using GCTP can be controlled by specifying the UTM zone or by supplying the geographic coordinate in parameters 1 and 2, from which the UTM zone is computed by GCTP. In a DLG file, the parameters are encoded as packed, degrees-minutes-seconds (DMS) as follows:

degrees $* 1000000+$ minutes $* 1000+$ seconds

Example: If degrees $=+50$, minutes $=30$, and seconds $=36.25$, then the parameter value is 50030036.25 stored as a REAL*8 variable, and "bb0.500300362500000D 08" encoded in FORTRAN D24.15 format. 
APPENDIX C.--Map Projection Parameters Universal Transverse Mercator (UTM)--continued

Codes for UTM Coordinate Zones

West Longitude (degrees)

$180-174$

$174-168$

$168-162$

$162-156$

$156-150$

$150-144$

$144-138$

$138-132$

$132-126$

$126-120$

$120-114$

$114-108$

108-102

102- 96

96- 90

90- 84

84- 78

78- 72

$72-66$

$66-60$
Zone

1

2

3

4

5

6

7

8

9

10

11

12

13

14

15

16

17

18

19

20 


\section{APPENDIX D.--DLG Attribute Codes}

Valid Minor Codes for the Coincident Feature Parameter

$\begin{array}{ll}\text { Code } & \text { Base Category } \\ 0002 & \text { Hypsography } \\ 0005 & \text { Hydrography } \\ 0007 & \text { Surface Cover } \\ 0009 & \text { Boundary } \\ 0015 & \text { Survey Control } \\ 0017 & \text { Transportation Systems } \\ 0018 & \text { Roads and Trails } \\ 0019 & \text { Railroads } \\ 0020 & \text { Pipelines, Transmission Lines, Miscellaneous } \\ & \text { Transportation }\end{array}$


APPENDIX D.--DLG Attribute Codes--continued

\begin{tabular}{|c|c|c|c|c|c|}
\hline DATA CATEGORY & TYPE OF CODE & APPLICATION & $\begin{array}{r}\text { MAJOR } \\
\text { CODE } \\
\end{array}$ & $\begin{array}{r}\text { MINOR } \\
\text { CODE } \\
\end{array}$ & DESCRIPTION \\
\hline \multirow[t]{21}{*}{ Hypsography } & Feature identification & Nodes & 020 & NONE & \\
\hline & & Areas & 020 & 0100 & Void area \\
\hline & & Lines & 020 & 0200 & Contour (index or intermediate) \\
\hline & & & & 0201 & Carrying contour \\
\hline & & & & 0202 & Supplementary contour \\
\hline & & & & 0203 & Continuation contour \\
\hline & & & & 0204 & Amended contour \\
\hline & & & & 0205 & Bathymetric contour \\
\hline & & & & $\star 0206$ & Depth curve \\
\hline & & & & 0207 & Watershed divides \\
\hline & & & & 0208 & Closure line \\
\hline & & $\begin{array}{l}\text { Points } \\
\text { (degenerate lines) }\end{array}$ & 020 & 0300 & $\begin{array}{l}\text { Spot elevation, less than } \\
\text { third order }\end{array}$ \\
\hline & & & 020 & 0301 & $\begin{array}{l}\text { Spot elevation, less than } \\
\text { third order, not at ground } \\
\text { level. }\end{array}$ \\
\hline & & $\begin{array}{l}\text { Multiple element } \\
\text { types }\end{array}$ & 020 & NONE & \\
\hline & Descriptive & $\begin{array}{l}\text { Multiple element } \\
\text { types }\end{array}$ & 020 & $\begin{array}{l}0600 \\
0609\end{array}$ & $\begin{array}{l}\text { Decimal fractions of feet } \\
\text { or meters }\end{array}$ \\
\hline & & & & 0610 & Approximate \\
\hline & & & & 0611 & Depression \\
\hline & & & & 0612 & Glacier or snow field \\
\hline & & & & 0613 & Underwater \\
\hline & & & & 0614 & $\begin{array}{l}\text { Best estimate of contour } \\
\text { elevation value }\end{array}$ \\
\hline & & & 020 & 0000 & Photorevised feature \\
\hline
\end{tabular}

* denotes a code which is no longer being used to encode features, but which may appear in older files. 
APPENDIX D.--DLG Attribute Codes--continued

\begin{tabular}{|c|c|c|c|c|c|}
\hline DATA CATEGORY & TYPE OF CODE & APPLICATION & $\begin{array}{l}\text { MAJOR } \\
\text { CODE }\end{array}$ & $\begin{array}{l}\text { MINOR } \\
\text { CODE }\end{array}$ & DESCRIPTION \\
\hline $\begin{array}{l}\text { Hypsography } \\
\text { (cont'd.) }\end{array}$ & Parameter & $\begin{array}{l}\text { Multiple element } \\
\text { types }\end{array}$ & $\begin{array}{l}02 \mathrm{~N} \\
026 \\
029\end{array}$ & $00--$ & $\begin{array}{l}\text { Elevation in whole feet or } \\
\text { meters, right-justified } \\
\text { Major category associated } \\
\text { with a spot height, not at } \\
\text { ground elevation. } \\
\text { Coincident feature }\end{array}$ \\
\hline Hydrography & Feature identification & Areas & 050 & $\begin{array}{l}0001 \\
0002 \\
0003 \\
0004 \\
0005 \\
0100 \\
0101 \\
0102 \\
0103 \\
0104 \\
0105 \\
0106 \\
0107 \\
0108 \\
0109 \\
0110 \\
0111 \\
0112 \\
0113 \\
0114 \\
0115 \\
0116 \\
0117 \\
0118 \\
0119 \\
0120\end{array}$ & $\begin{array}{l}\text { Upper origin of stream } \\
\text { Upper origin of stream at water body } \\
\text { Sink, channel no longer evident } \\
\text { Stream entering water body } \\
\text { Stream exiting water body } \\
\text { Alkali flat } \\
\text { Reservoir } \\
\text { Covered reservoir } \\
\text { Glacier or permanent snowfield } \\
\text { Salt evaporator } \\
\text { Inundation area } \\
\text { Fish hatchery or farm } \\
\text { Industrial water impoundment } \\
\text { Area to be submerged } \\
\text { Sewage disposal pond or } \\
\text { filtration beds } \\
\text { Tailings pond } \\
\text { Marsh, wetland, swamp, bog } \\
\text { Mangrove area } \\
\text { Rice field } \\
\text { Cranberry bog } \\
\text { Flats (tidal, mud, sand, gravel) } \\
\text { Bays, estuaries, gulfs, oceans, seas } \\
\text { Shoal } \\
\text { Soda evaporator } \\
\text { Duck Pond } \\
\text { Void area }\end{array}$ \\
\hline
\end{tabular}


APPENDIX D.--DLG Attribute Codes---continued

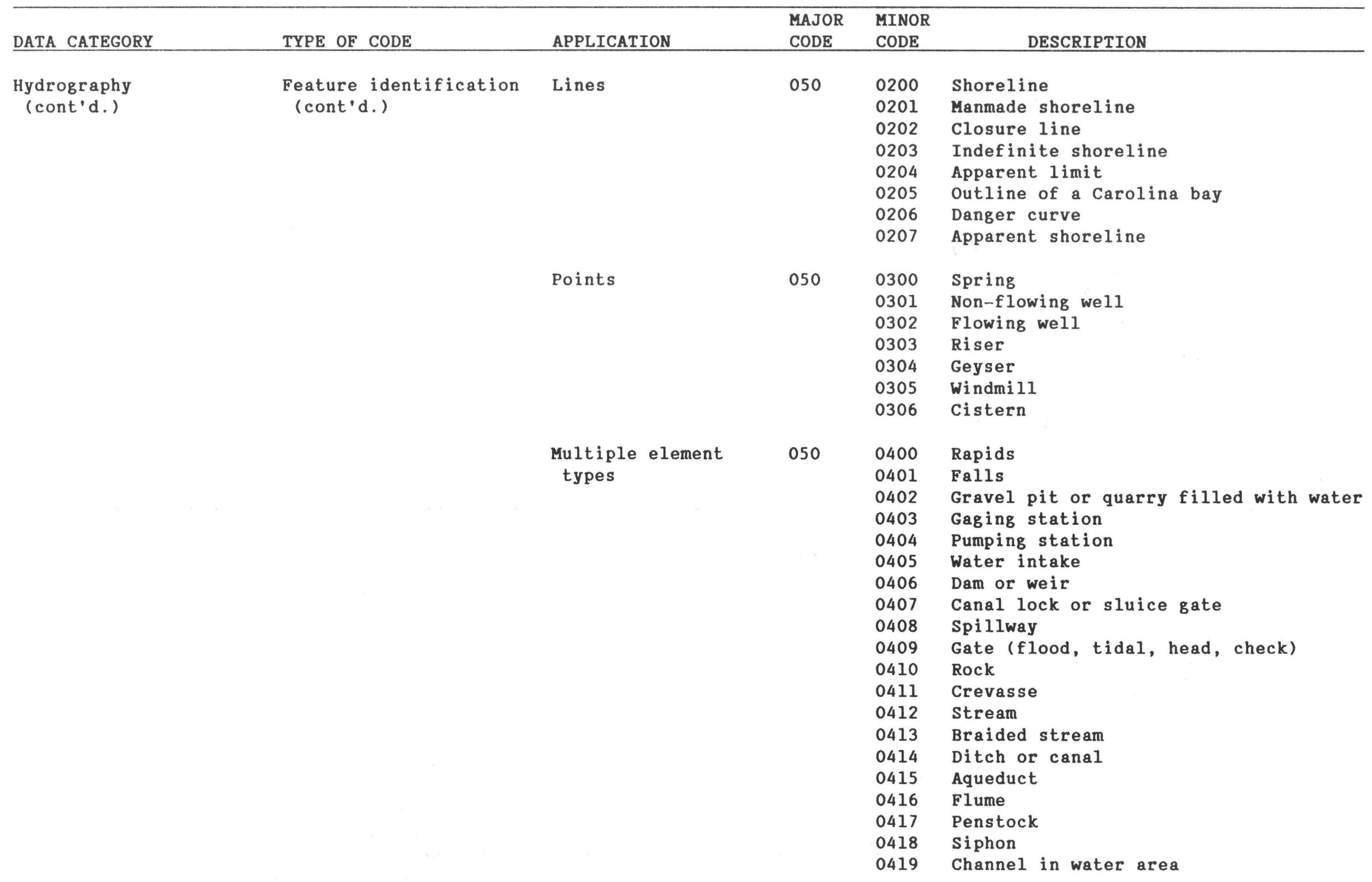


APPENDIX D.--DLG Attribute Codes--continued

DATA CATEGORY

Hydrography

(cont'd.)
MAJOR MINOR

CODE CODE

$050 \quad 0420$

Feature identification Multiple element (cont'd.)

types (cont'd.)

Descriptive

Multiple element types

050

0420

0422

0423

0424

0425

0426

0601

0602

0603

0604

0605

0606

0607

0608

0609

0610

0611

0612

*0613

0614

0615

0616

0617

0618

0619

0621 -

0629

$050 \quad 0000$

Photorevised feature

Parameter

Multiple element

05N
DESCRIPTION

Wash or ephemeral drain

Lake or pond

Coral reef

Sand in open water

Spoil area

Fish ladders

Holiday area

Underground

Overpassing

Elevated

Tunnel

Right bank

Left bank

Under construction

Salt

Unsurveyed

Intermittent

Abandoned or discontinued

Submerged or sunken

Wooded

Dry

Mineral or hot (sulphur, alkali, etc.) Navigable, transportation

Underpassing

Earthen construction

Interpolated elevation

Decimal fractions of feet or meters

Water surface elevation, actual or

interpolated, $\mathrm{N}=1$ for feet,

2 for meters, 6 for feet below datum, and 7 for meters below datum.

Elevation value in four spaces,

right justified. 
APPENDIX D.--DLG Attribute Codes--continued

\begin{tabular}{|c|c|c|c|c|c|}
\hline DATA CATEGORY & TYPE OF CODE & APPLICATION & $\begin{array}{l}\text { MAJOR } \\
\text { CODE }\end{array}$ & $\begin{array}{l}\text { MINOR } \\
\text { CODE }\end{array}$ & DESCRIPTION \\
\hline \multirow[t]{4}{*}{$\begin{array}{l}\text { Hydrography } \\
\text { (cont'd.) }\end{array}$} & Parameter (cont'd.) & $\begin{array}{l}\text { Multiple element } \\
\text { types (cont'd.) }\end{array}$ & 053 & $0--$ & $\begin{array}{l}\text { Angle of clockwise rotation (nearest } \\
\text { whole degree) }\end{array}$ \\
\hline & & & 055 & --- & $\begin{array}{l}\text { River mile, value in four spaces, } \\
\text { right justified }\end{array}$ \\
\hline & & & 058 & 0000 & $\begin{array}{l}\text { Best estimate of classification } \\
\text { or position }\end{array}$ \\
\hline & & & 059 & $00--$ & Coincident feature \\
\hline
\end{tabular}

Boundaries

Feature identification Nodes

Areas
$090 \quad 0001$ Monumented point on a boundary

0900100 Civil township, district, precinct, or barrio

0101 Incorporated city, village, town, borough, or hamlet

0103 National park, monument, lakeshore, seashore, parkway, battlefield, or recreation area

0104 National forest or grassland

0105 National wildlife refuge, game preserve, or $\mathrm{f} i \mathrm{sh}$ hatchery

0106 National scenic waterway, riverway, wild and scenic river, or wilderness area

0107 Indian reservation

0108 Military reservation

0110 Federal prison

0111 Miscellaneous Federal reservation

0129 Miscellaneous state reservation

0130 State park, recreation area, arboretum, or lake

0131 State wildlife refuge, game preserve, or $f$ ish hatchery

0132 State forest or grassland

0133 State prison

0134 County game preserve 
APPENDIX D.--DLG Attribute Codes--continued

\begin{tabular}{|c|c|c|c|c|c|}
\hline DATA CATEGORY & TYPE OF CODE & APPLICATION & $\begin{array}{l}\text { MAJOR } \\
\text { CODE }\end{array}$ & $\begin{array}{l}\text { MINOR } \\
\text { CODE }\end{array}$ & DESCRIPTION \\
\hline \multirow[t]{6}{*}{ Boundaries (cont'd.) } & $\begin{array}{l}\text { Feature identification } \\
\quad(\text { cont'd.) }\end{array}$ & Areas (cont'd.) & 090 & $\begin{array}{l}0150 \\
0151 \\
0197 \\
0198 \\
0199\end{array}$ & $\begin{array}{l}\text { Large park (city, county, or private) } \\
\text { Small park (city, county, or private) } \\
\text { Canada } \\
\text { Mexico } \\
\text { Open water }\end{array}$ \\
\hline & & Lines & 090 & $\begin{array}{l}0201 \\
0202 \\
0203 \\
0204\end{array}$ & $\begin{array}{l}\text { Indefinite (or approximate) boundary } \\
\text { Disputed boundary } \\
\text { Historical line } \\
\text { Boundary closure line }\end{array}$ \\
\hline & & $\begin{array}{l}\text { Points } \\
\text { (degenerate lines) }\end{array}$ & 090 & 0301 & $\begin{array}{l}\text { Reference monuments for boundary } \\
\text { points }\end{array}$ \\
\hline & & $\begin{array}{l}\text { Multiple element } \\
\text { types }\end{array}$ & 090 & NONE & \\
\hline & Descriptive & $\begin{array}{l}\text { Multiple element } \\
\text { types }\end{array}$ & 090 & 0000 & Photorevised feature \\
\hline & Parameter & $\begin{array}{l}\text { Multiple element } \\
\text { types }\end{array}$ & $\begin{array}{l}091 \\
092 \\
095 \\
096\end{array}$ & \begin{tabular}{l}
$00--$ \\
$0---$ \\
\hdashline--- \\
XXYY
\end{tabular} & $\begin{array}{l}\text { State FIPS code } \\
\text { County or county equivalent FIPS code } \\
\text { Monument number } \\
\text { Alphabetic portion of any monument } \\
\text { number substitute numeric equivalent } \\
\text { of alphabetic for XX and for YY as } \\
\text { follows: } 00 \text { blank, } 01=\mathrm{A}, 02=\mathrm{B} \text {, } \\
03=\mathrm{C}, 04=\mathrm{D}, 05=\mathrm{E}, 06=\mathrm{F}, \\
07=\mathrm{G}, 08=\mathrm{H}, 09=\mathrm{I}, 10=\mathrm{J}, \\
11=\mathrm{K}, 12=\mathrm{L}, 13=\mathrm{M}, 14=\mathrm{N}, \\
15=0,16=\mathrm{P}, 17=\mathrm{Q}, 18=\mathrm{R}, \\
19=\mathrm{S}, 20=\mathrm{T}, 21=\mathrm{U}, 22=\mathrm{V}, \\
23=\mathrm{W}, 24=\mathrm{X}, 25=\mathrm{Y}, 26=\mathrm{Z} \text {. } \\
\text { Best estimate of classification } \\
\text { or position. } \\
\text { Coincident feature }\end{array}$ \\
\hline
\end{tabular}


APPENDIX D.--DLG Attribute Codes--continued

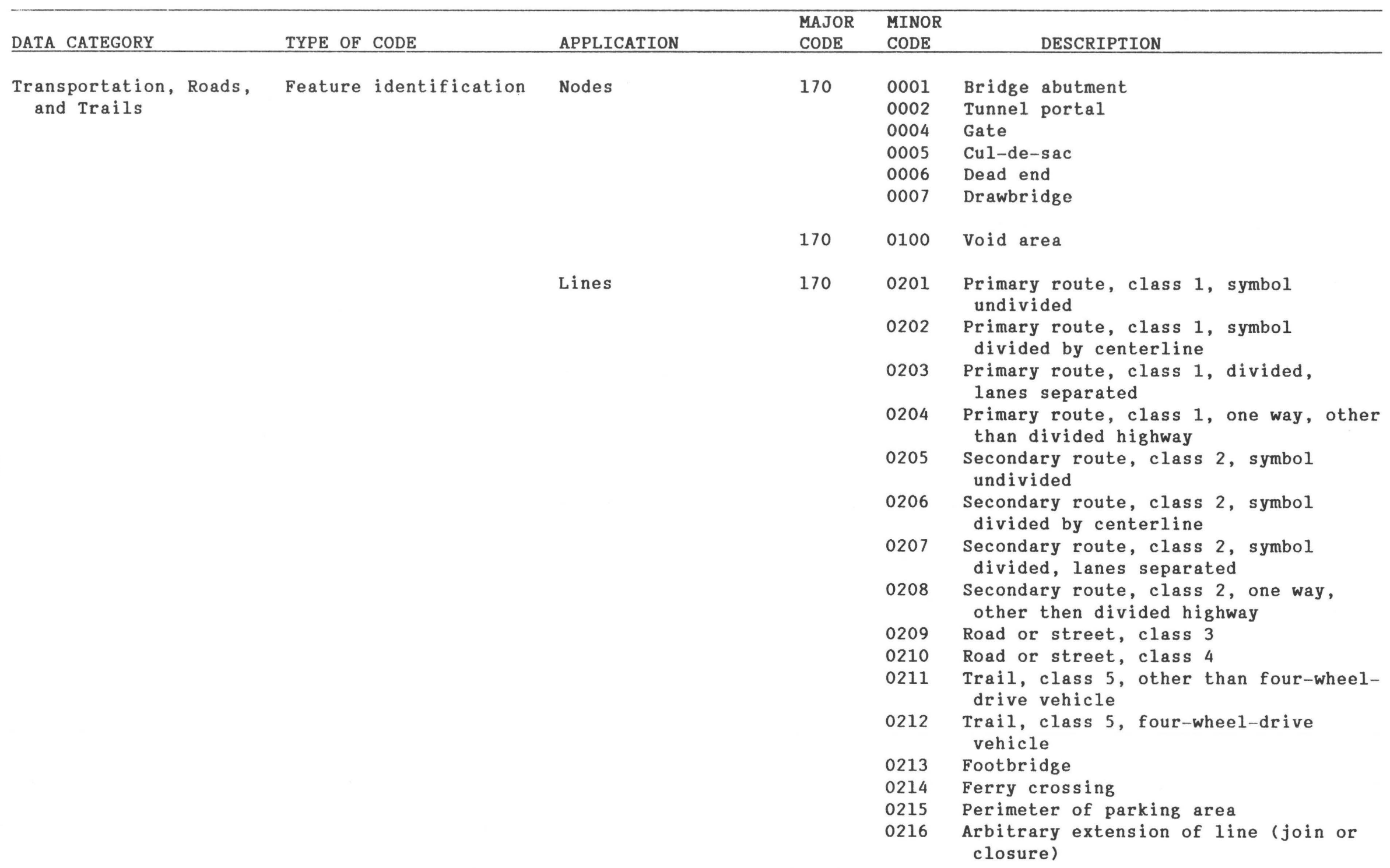


APPENDIX D.--DLG Attribute Codes--continued

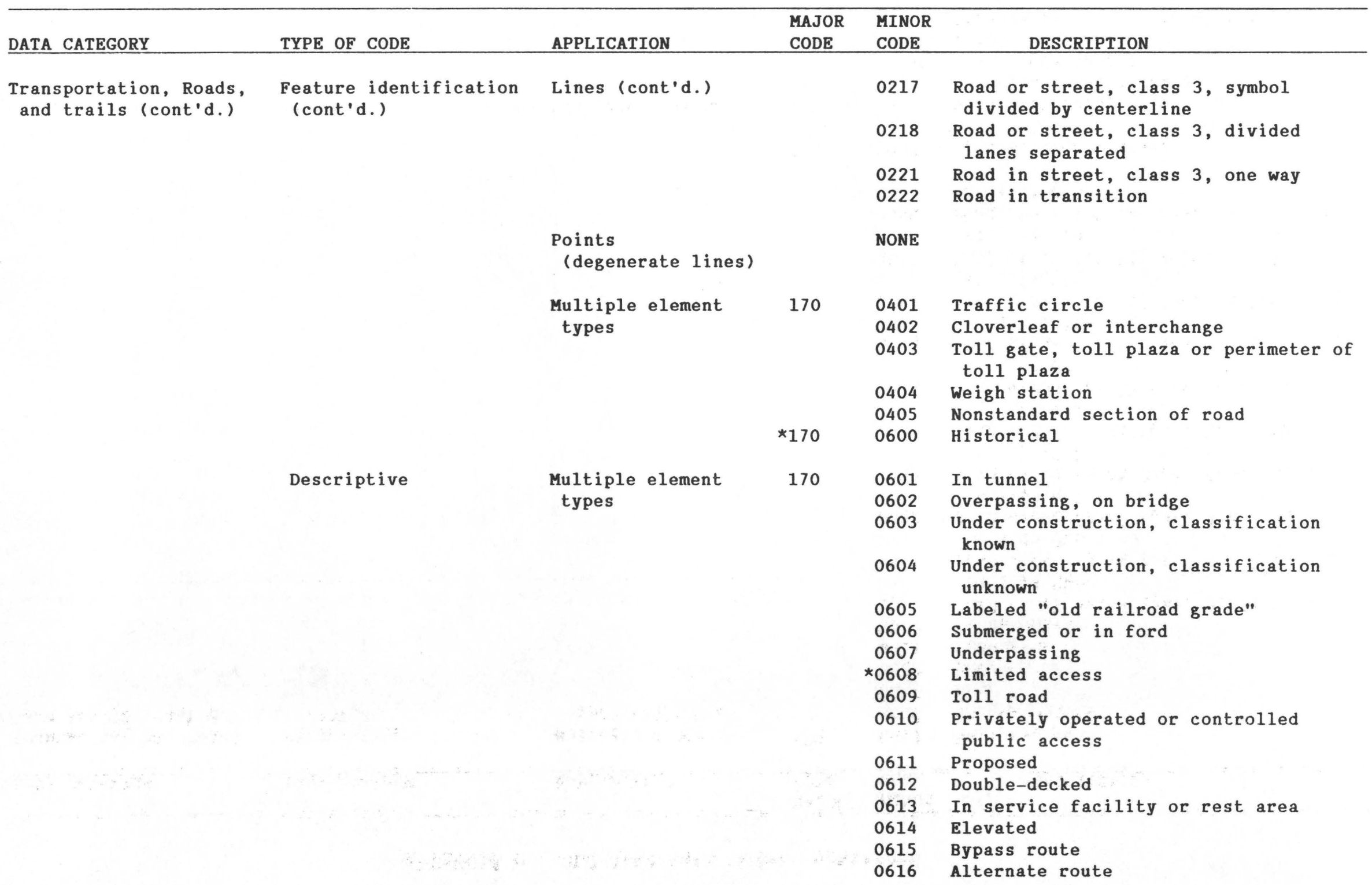


APPENDIX D.--DLG Attribute Codes--continued

\begin{tabular}{|c|c|c|c|c|c|}
\hline DATA CATEGORY & TYPE OF CODE & APPLICATION & $\begin{array}{l}\text { MAJOR } \\
\text { CODE }\end{array}$ & $\begin{array}{l}\text { MINOR } \\
\text { CODE }\end{array}$ & DESCRIPTION \\
\hline \multirow[t]{22}{*}{$\begin{array}{l}\text { Transportation, Roads, } \\
\text { and trails (cont'd.) }\end{array}$} & $\begin{array}{l}\text { Descriptive } \\
\text { (cont'd.) }\end{array}$ & $\begin{array}{l}\text { Multiple element } \\
\text { types (cont'd.) }\end{array}$ & 170 & $\begin{array}{l}0617 \\
0618\end{array}$ & $\begin{array}{l}\text { Business route } \\
\text { On drawbridge }\end{array}$ \\
\hline & & & & 0619 & Spur \\
\hline & & & & 0620 & Loop \\
\hline & & & & 0621 & Connector \\
\hline & & & & 0622 & Truck route \\
\hline & & & & 0650 & $\begin{array}{l}\text { Road width } 46-55 \text { feet, } 0.025 \text { inches } \\
\text { at } 1: 24,000\end{array}$ \\
\hline & & & & 0651 & $\begin{array}{l}\text { Road width } 56-65 \text { feet, } 0.030 \text { inches } \\
\text { at } 1: 24,000\end{array}$ \\
\hline & & & & 0652 & $\begin{array}{l}\text { Road width } 66-75 \text { feet, } 0.035 \text { inches } \\
\text { at } 1: 24,000\end{array}$ \\
\hline & & & & 0653 & $\begin{array}{l}\text { Road width } 76-85 \text { feet, } 0.040 \text { inches } \\
\text { at } 1: 24,000\end{array}$ \\
\hline & & & & 0654 & $\begin{array}{l}\text { Road width } 86-95 \text { feet, } 0.045 \text { inches } \\
\text { at } 1: 24,000\end{array}$ \\
\hline & & & & 0655 & $\begin{array}{l}\text { Road width } 96-105 \text { feet, } 0.050 \text { inches } \\
\text { at } 1: 24,000\end{array}$ \\
\hline & & & & 0656 & $\begin{array}{l}\text { Road width 106-115 feet, } 0.055 \text { inches } \\
\text { at } 1: 24,000\end{array}$ \\
\hline & & & & 0657 & $\begin{array}{l}\text { Road width } 116-125 \text { feet, } 0.060 \text { inches } \\
\text { at } 1: 24,000\end{array}$ \\
\hline & & & & 0658 & $\begin{array}{l}\text { Road width } 126-135 \text { feet, } 0.065 \text { inches } \\
\text { at } 1: 24,000\end{array}$ \\
\hline & & & & 0659 & $\begin{array}{l}\text { Road width } 136-145 \text { feet, } 0.070 \text { inches } \\
\text { at } 1: 24,000\end{array}$ \\
\hline & & & 170 & 0000 & Photorevised feature \\
\hline & Parameter & Multiple element & 171 & --- & Number of lanes \\
\hline & & types & 172 & --- & Interstate route number \\
\hline & & & 173 & --- & U.S. route number \\
\hline & & & 174 & --- & State route number \\
\hline & & & 175 & ---- & $\begin{array}{l}\text { Reservation, park, or military route } \\
\text { number }\end{array}$ \\
\hline & & & 176 & $-\cdots$ & County route \\
\hline
\end{tabular}


APPENDIX D.--DLG Attribute Codes--continued

\begin{tabular}{|c|c|c|c|c|c|}
\hline DATA CATEGORY & TYPE OF CODE & APPLICATION & $\begin{array}{l}\text { MAJOR } \\
\text { CODE } \\
\end{array}$ & $\begin{array}{l}\text { MINOR } \\
\text { CODE }\end{array}$ & DESCRIPTION \\
\hline $\begin{array}{l}\text { Transportation, Roads, } \\
\text { and Trails (cont'd.) }\end{array}$ & Parameter (cont'd.) & $\begin{array}{l}\text { Multiple element } \\
\text { types (cont'd.) }\end{array}$ & 178 & 0000 & 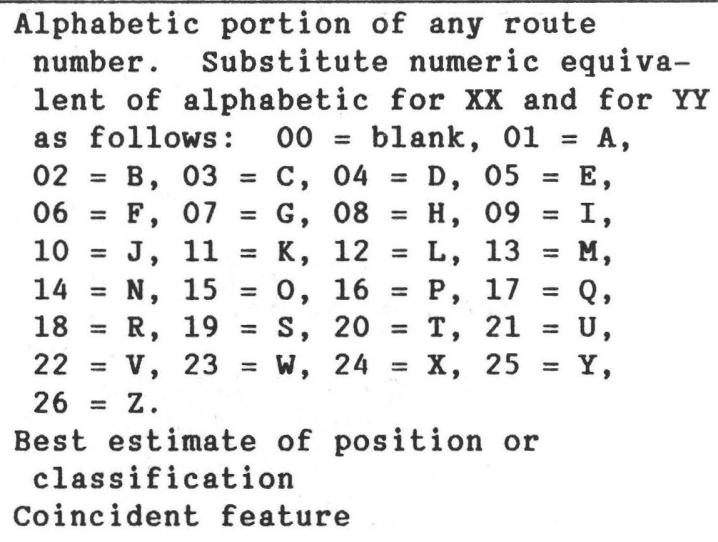 \\
\hline \multirow[t]{5}{*}{$\begin{array}{l}\text { Transportation, } \\
\text { Railroads }\end{array}$} & Feature identification & Nodes & 180 & $\begin{array}{l}0001 \\
0002 \\
0007\end{array}$ & $\begin{array}{l}\text { Bridge abutment } \\
\text { Tunnel portal } \\
\text { Drawbridge }\end{array}$ \\
\hline & & Areas & 180 & 0100 & Void area \\
\hline & & Lines & 180 & $\begin{array}{l}0201 \\
0202 \\
0204 \\
0205 \\
0207 \\
0208 \\
0209 \\
0210 \\
0211\end{array}$ & $\begin{array}{l}\text { Railroad } \\
\text { Railroad in street or road } \\
\text { Carline } \\
\text { Cog railroad, incline railway, } \\
\text { logging tram } \\
\text { Ferry crossing } \\
\text { Railroad siding } \\
\text { Perimeter or limit of yard } \\
\text { Arbitrary line extension } \\
\text { Closure line }\end{array}$ \\
\hline & & $\begin{array}{l}\text { Points } \\
\text { (degenerate } 1 \text { ines) }\end{array}$ & 180 & NONE & \\
\hline & & $\begin{array}{l}\text { Multiple element } \\
\text { types }\end{array}$ & *180 & $\begin{array}{l}0400 \\
0401 \\
0402 \\
0600\end{array}$ & $\begin{array}{l}\text { Railroad station, perimeter of } \\
\text { station } \\
\text { Turntable } \\
\text { Roundhouse } \\
\text { Historical }\end{array}$ \\
\hline
\end{tabular}


APPENDIX D.--DLG Attribute Codes--continued

\begin{tabular}{|c|c|c|c|c|c|}
\hline DATA CATEGORY & TYPE OF CODE & APPLICATION & $\begin{array}{l}\text { MAJOR } \\
\text { CODE }\end{array}$ & $\begin{array}{l}\text { MINOR } \\
\text { CODE }\end{array}$ & DESCRIPTION \\
\hline $\begin{array}{l}\text { Transportation, } \\
\text { Railroads (cont'd.) }\end{array}$ & Descriptive & $\begin{array}{l}\text { Multiple element } \\
\text { types }\end{array}$ & 180 & $\begin{array}{l}0601 \\
0602 \\
0603 \\
0604 \\
0605 \\
0606 \\
0607 \\
0608 \\
0609 \\
0610 \\
0611 \\
0612 \\
0613 \\
0614\end{array}$ & $\begin{array}{l}\text { In tunnel } \\
\text { Overpassing, on bridge } \\
\text { Abandoned } \\
\text { Dismantled } \\
\text { Underpassing } \\
\text { Narrow gauge } \\
\text { In snowshed or under structure } \\
\text { Under construction } \\
\text { Elevated } \\
\text { Rapid transit } \\
\text { On drawbridge } \\
\text { Private } \\
\text { U.S. Government } \\
\text { Juxtaposition }\end{array}$ \\
\hline & Parameter & $\begin{array}{l}\text { Multiple element } \\
\text { types }\end{array}$ & $\begin{array}{l}180 \\
181 \\
188 \\
189\end{array}$ & $\frac{0000}{0000}$ & $\begin{array}{l}\text { Photorevised feature } \\
\text { Number of tracks } \\
\text { Best estimate of position or } \\
\text { classification } \\
\text { Coincident feature }\end{array}$ \\
\hline $\begin{array}{l}\text { Transportation, } \\
\text { Pipelines, Trans- } \\
\text { mission Lines, } \\
\text { Miscellaneous Trans- } \\
\text { portation Features }\end{array}$ & Feature identification & $\begin{array}{l}\text { Areas } \\
\text { Lines }\end{array}$ & 190 & $\begin{array}{l}0001 \\
0002 \\
0003 \\
0100 \\
0201 \\
0202 \\
0203 \\
0204 \\
0205 \\
0206\end{array}$ & $\begin{array}{l}\text { End of transmission line at } \\
\text { power station, substation, or } \\
\text { hydroelectric plant } \\
\text { End of pipeline at oil or gas } \\
\text { field } \\
\text { End of pipeline at refinery, } \\
\text { depot, or tank farm } \\
\text { Void area } \\
\text { Pipeline } \\
\text { Power transmission line } \\
\text { Telephone or telegraph line } \\
\text { Aerial tramway, monorail, ski } \\
\text { lift } \\
\text { Arbitrary line extension } \\
\text { Closure line }\end{array}$ \\
\hline
\end{tabular}


APPENDIX D.--DLG Attribute Codes--continued

\begin{tabular}{|c|c|c|c|c|}
\hline DATA CATEGORY & APPLICATION & $\begin{array}{l}\text { MAJOR } \\
\text { CODE }\end{array}$ & $\begin{array}{l}\text { MINOR } \\
\text { CODE }\end{array}$ & DESCRIPTION \\
\hline \multirow{21}{*}{$\begin{array}{l}\text { Transportation, } \\
\text { Pipelines, Trans- } \\
\text { mission Lines, } \\
\text { Miscellaneous Trans- } \\
\text { portation Features (cont }\end{array}$} & $\begin{array}{l}\text { Points } \\
\text { (degenerate lines) }\end{array}$ & 190 & 0300 & Seaplane anchorage \\
\hline & $\begin{array}{l}\text { Multiple element } \\
\text { types }\end{array}$ & 190 & $\begin{array}{l}0400 \\
0401\end{array}$ & $\begin{array}{l}\text { Power station } \\
\text { Substation }\end{array}$ \\
\hline & & & 0402 & Hydroelectric Plant \\
\hline & & 190 & 0403 & $\begin{array}{l}\text { Landing strip, airport, } \\
\text { perimeter of airport }\end{array}$ \\
\hline & & & 0404 & Heliport, perimeter of heliport \\
\hline & & & 0405 & $\begin{array}{l}\text { Launch complex, perimeter of } \\
\text { launch complex }\end{array}$ \\
\hline & & & 0406 & $\begin{array}{l}\text { Pumping station (other than } \\
\text { water) }\end{array}$ \\
\hline & & & 0407 & Seaplane ramp or landing area \\
\hline & & & 0408 & Measuring station \\
\hline & Multiple element & 190 & 0600 & Underground \\
\hline & types & & 0601 & Under construction \\
\hline & & & 0602 & Abandoned \\
\hline & & & 0603 & Above ground \\
\hline & & & 0604 & Labeled "closed" \\
\hline & & & 0605 & Unimproved, loose surface \\
\hline & & & 0606 & Submerged \\
\hline & & & 0607 & Nuclear \\
\hline & & 190 & 0000 & Photorevised feature \\
\hline & $\begin{array}{l}\text { Multiple element } \\
\text { types }\end{array}$ & 193 & $0--$ & $\begin{array}{l}\text { Angle of clockwise rotation } \\
\text { (nearest whole degree) }\end{array}$ \\
\hline & & 198 & 0000 & $\begin{array}{l}\text { Best estimate of position or } \\
\text { classification }\end{array}$ \\
\hline & & 199 & $00--$ & Coincident feature \\
\hline
\end{tabular}


APPENDIX D.--DLG Attribute Codes--continued

\begin{tabular}{|c|c|c|c|c|c|}
\hline DATA CATEGORY & TYPE OF CODE & APPLICATION & $\begin{array}{l}\text { MAJOR } \\
\text { CODE }\end{array}$ & $\begin{array}{l}\text { MINOR } \\
\text { CODE }\end{array}$ & DESCRIPTION \\
\hline \multirow[t]{3}{*}{$\begin{array}{l}\text { U.S. Public Land } \\
\text { Survey System }\end{array}$} & Feature identification & Nodes & 300 & $\begin{array}{l}0001 \\
0002 \\
0003 \\
0004 \\
0005 \\
0006 \\
0007 \\
0008 \\
0009 \\
0010 \\
0011 \\
0012 \\
0013 \\
0014 \\
0015\end{array}$ & $\begin{array}{l}\text { U.S. Public Land Survey System } \\
\text { section corner } \\
\text { Point on section line (no corner) } \\
\text { Closing corner } \\
\text { Meander corner } \\
\text { Auxiliary meander corner } \\
\text { Special meander corner } \\
\text { Witness corner } \\
\text { Witness point } \\
\text { Angle point } \\
\text { Location monument (includes amended } \\
\text { monument and mineral monument) } \\
\text { Reference mark } \\
\text { Quarter-section corner } \\
\text { Tract corner } \\
\text { Land grant corner } \\
\text { Arbitrary section corner }\end{array}$ \\
\hline & & $\begin{array}{l}\text { Nodes (identifi- } \\
\text { cation procedures) }\end{array}$ & 300 & $\begin{array}{l}0040 \\
0041 \\
0042\end{array}$ & $\begin{array}{l}\text { Corner identified in field } \\
\text { Corner with horizontal coordinates } \\
\text { Corner with elevation value }\end{array}$ \\
\hline & Parameters & Areas & & & $\begin{array}{l}\text { Select one parameter code from each of } \\
\text { the following } A, B, C \text {, and D lists } \\
\text { and/or consult list } E \text {. }\end{array}$ \\
\hline
\end{tabular}

\section{A. Origin of Survey}

00-- Insert two-digit code from Appendix $K$.

B. Township number(s)

$30-$

Insert 2 for north of the baseline or 3 for south of the baseline in first space. In the second space, insert a 0 for full township, 2 for $1 / 4$ township, 4 for $1 / 2$ township, or 6 for $3 / 4$ township. Insert township number in the last three spaces, right justified. 
APPENDIX D.--DLG Attribute Codes--continued

\begin{tabular}{|c|c|c|c|c|c|}
\hline 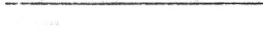 & & & MAJOR & MINOR & \\
\hline DATA CATEGORY & TYPE OF CODE & APPLICATION & CODE & CODE & DESCRIPTION \\
\hline
\end{tabular}

\section{U.S. Public Land} Survey System

(cont'd.)

\section{Parameters}

(cont'd.)

Areas (cont'd.)

$30-$

301
C. Range number(s)

Insert 4 for east of the principal meridian or 5 for west of the principal meridian in the first space. In the second space, insert a 0 for a full range, 2 for $1 / 4$ range, 4 for $1 / 2$ range, 6 for $3 / 4$ range, 8 for duplicate to the north or east of the original township, or

9 for triplicate to the north or east of the original township. Insert range number in last three spaces, right justified.

D. Section number

In the first space, insert 0 for numeric section identifier, 1 for numeric portion of alphanumeric identifier, or 2 for alphabetic part of alphanumeric identifier. In the last three spaces, insert section number or numeric representation of alphabetic character (01-26), right justified.

E. Land grant identifier

307 - In the first space, insert the appropriate number:

for numeric grant identifier

for numeric portion of alphanumeric identifier

for alphabetic portion of

alphanumeric identifier

for alphabetic identifier

for identifier of named grant in

Arizona 
APPENDIX D.--DLG Attribute Codes--.continued

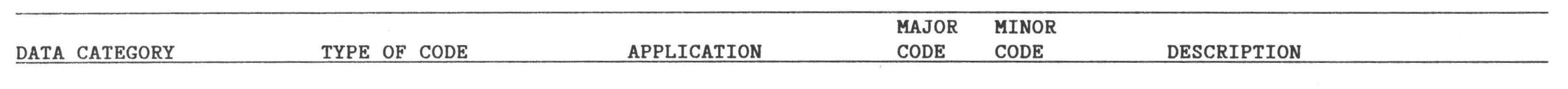

$\begin{array}{lr}\text { U.S. Public Land } & \text { Parameters } \\ \begin{array}{l}\text { Survey System } \\ \text { (cont'd.) }\end{array} & (\text { cont'd.) }\end{array}$

(cont'd.)

5

6.

7

8 for identifier of named grant in California

for identifier of named grant in Colorado

for identifier of named grant in New Mexico

For identifier of named grant in other states

In the last three spaces after $0-3$ above, insert the grant number or numeric representation of the alphabetic character $(01-26)$, right-justified. In the last three spaces after 4-7 above, insert the three-digit code of the named grant as designated in Appendix L.

F. Excluded areas

ian lands

Homestead entries

Donation land claims

0103 Land grants; civil colonies

0104 Private extension of public land survey

0105

Area of public and private survey overlap

0106 Overlapping land grants

0107 Military reservation

0198 Water

0199 Unsurveyed area

Approximate position (within 200 feet) Protracted position Arbitrary closure line Base line

Claim line, grant line

\section{Points}

0300

(degenerate 1 ines)
0300

0301

Location monument

0302
Isolated found section corner Witness corner (off surveyed line) 
APPENDIX D.--DLG Attribute Codes--continued

\begin{tabular}{|c|c|c|c|c|c|}
\hline DATA CATEGORY & TYPE OF CODE & APPLICATION & $\begin{array}{l}\text { MAJOR } \\
\text { CODE }\end{array}$ & $\begin{array}{l}\text { MINOR } \\
\text { CODE }\end{array}$ & DESCRIPTION \\
\hline $\begin{array}{l}\text { U.S. Public Land } \\
\text { Survey System } \\
\text { (cont'd.) }\end{array}$ & Parameter & $\begin{array}{l}\text { Multiple element } \\
\text { types }\end{array}$ & $\begin{array}{l}308 \\
309\end{array}$ & 0000 & $\begin{array}{l}\text { Best estimate of classification and/or } \\
\text { position } \\
\text { Coincident feature or symbol }\end{array}$ \\
\hline
\end{tabular}

* denotes a code which is no longer being used to encode features, but which may appear in older files. 
This appendix illustrates the procedure for converting the internal file coordinates of the standard DLG format to the ground planimetric UTM reference coordinates. The formulas for this conversion, representing a simple offset, rotation, and scale, are as follows:

$$
\begin{aligned}
& X=A 1 x+A 2 y+A 3, \text { and } \\
& Y=A 1 y-A 2 x+A 4,
\end{aligned}
$$

where $X$ and $Y$ are the ground planimetric coordinate values and $\mathrm{x}$ and $\mathrm{y}$ are the internal file coordinates.

The parameters for these formulas ( $A 1, A 2, A 3$, and $A 4$ ) are contained in Header Record B, as double-precision floating-point numbers.

This example converts four coordinate pairs from internal file coordinates to ground planimetric UTM zone 10 coordinate values. The parameters are as follows:

$$
\begin{aligned}
& \mathrm{A} 1=.60959440759 \\
& \mathrm{~A} 2=-.0028817856942 \\
& \mathrm{~A} 3=538248.79341 \\
& \mathrm{~A} 4=4240374.4556
\end{aligned}
$$

The internal file coordinates to be converted are as follows:

$\begin{array}{lrr} & & \\ & & y \\ \text { 1st pair } & -8971^{*} & -11376 \\ \text { 2nd pair } & -8955 & 11375 \\ \text { 3rd pair } & 8955 & 11376 \\ \text { 4th pair } & 8971 & -11376\end{array}$

The calculations to determine the ground planimetric coordinates for the first pair are as follows:

$$
\begin{aligned}
\mathrm{X}= & (0.60959440759)(-8971)+(-0.0028817856942)(-11376) \\
& +(538248.79341) \\
= & 532812.91 \\
\mathrm{Y} & (0.60959440759)(-11376)-(-0.0028817856942)(-8971) \\
& +(4240374.4556) \\
= & 4233413.86
\end{aligned}
$$

The resulting $\mathrm{X}, \mathrm{Y}$ coordinate values for the four pairs are as follows:

$\mathrm{X}$

$$
\begin{array}{ll}
\text { 1st pair } & 532,812.91 \\
\text { 2nd pair } & 532,757.10 \\
\text { 3rd pair } & 543,674.93 \\
\text { 4th pair } & 543,750.25
\end{array}
$$

$\mathrm{Y}$

$$
\begin{aligned}
& 4,233,413.86 \\
& 4,247,282.79 \\
& 4,247,335.01 \\
& 4,233,465.56
\end{aligned}
$$


APPENDIX F.--Sample DLG Data File

(Standard Distribution Format)

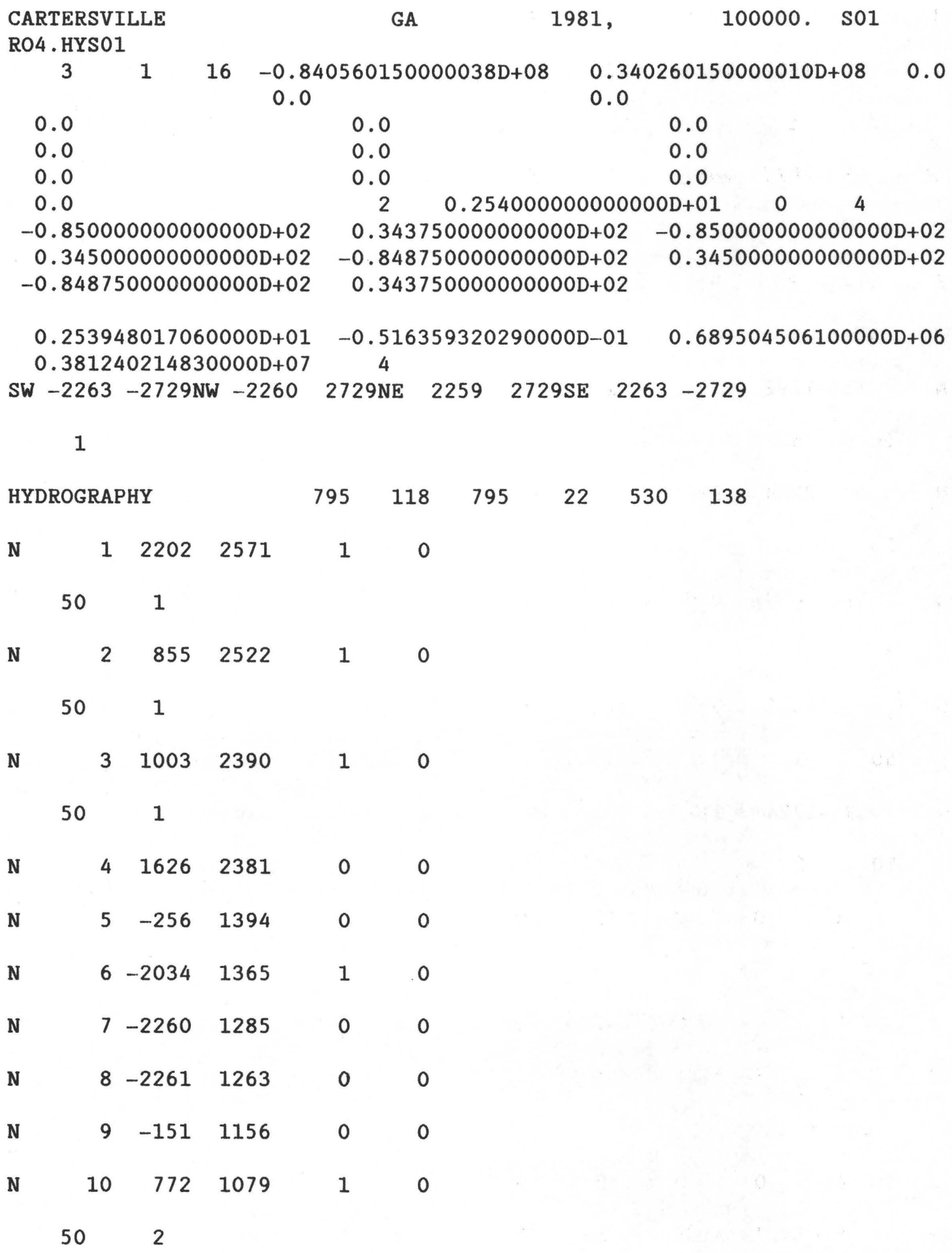




\begin{tabular}{|c|c|c|c|c|c|}
\hline $\mathrm{N}$ & 11 & -1698 & 1059 & 0 & $c$ \\
\hline \multirow[t]{2}{*}{$\mathbf{N}$} & 12 & 1912 & 1028 & 1 & 0 \\
\hline & 50 & 1 & & & \\
\hline \multirow[t]{2}{*}{$\mathbf{N}$} & 13 & -828 & 1011 & 1 & 0 \\
\hline & 50 & 1 & & & \\
\hline \multirow[t]{2}{*}{ N } & 14 & -932 & 957 & 1 & 0 \\
\hline & 50 & 1 & & & \\
\hline \multirow[t]{2}{*}{$\mathrm{N}$} & 15 & -1292 & 929 & 1 & 0 \\
\hline & 50 & 5 & & & \\
\hline \multirow[t]{2}{*}{$\mathbf{N}$} & 16 & -2139 & 922 & 1 & 0 \\
\hline & 50 & 1 & & & \\
\hline \multirow[t]{2}{*}{$\mathbf{N}$} & 17 & 489 & 919 & 1 & 0 \\
\hline & 50 & 2 & & & \\
\hline \multirow[t]{2}{*}{$\mathrm{N}$} & 18 & 2162 & 697 & 1 & 0 \\
\hline & 50 & 1 & & & \\
\hline \multirow[t]{2}{*}{$\mathbf{N}$} & 19 & -1724 & 212 & 1 & 0 \\
\hline & 50 & 2 & & & \\
\hline \multirow[t]{2}{*}{ A } & 1 & 0 & 0 & 1 & \\
\hline & 0 & 0 & & & \\
\hline A & 2 & 0 & 0 & 0 & \\
\hline \multirow[t]{2}{*}{ A } & 3 & $3 \quad 1533$ & 2471 & 1 & \\
\hline & 50 & 106 & & & \\
\hline A & 4 & 0 & 0 & 0 & \\
\hline A & 5 & -2057 & 1523 & 1 & \\
\hline & 50 & 412 & & & \\
\hline
\end{tabular}


APPENDIX F.--Sample DLG Data File

(Standard Distribution Format)--continued
A $\quad 6 \quad 0 \quad 00000$
$\begin{array}{llllll}\text { A } & 7 & 797 & 1119 & 1 & 0\end{array}$
$50 \quad 421$

A

$\begin{array}{lllll}8 & -1243 & 770 & 1 & 0\end{array}$

$50 \quad 421$

$\begin{array}{llllll}\text { A } & 9 & 530 & 916 & 1 & 0\end{array}$

$50 \quad 421$

$\begin{array}{llllll}\text { A } & 10 & -1711 & 129 & 1 & 0\end{array}$

$50 \quad 421$

A $\quad 11 \quad 0 \quad 00000$

$\begin{array}{llllll}\text { A } & 12 & -1726 & -1658 & 1 & 0\end{array}$

$50 \quad 421$

$\begin{array}{llllll}\text { A } & 13 & 0 & 0 & 0 & 0\end{array}$

$50 \quad 106$

$\begin{array}{llllll}\text { A } & 17 & 1365 & 2584 & 1 & 0\end{array}$

$50 \quad 106$

$\begin{array}{llllll}\text { A } & 18 & 0 & 0 & 0 & 0\end{array}$

$\begin{array}{llllll}\text { A } & 19 & 841 & 1803 & 1 & 0\end{array}$

$50 \quad 421$

A $20 \quad 0 \quad 00000$

$\begin{array}{llllll}\text { A } & 21 & 819 & -440 & 1 & 0\end{array}$

$50 \quad 421$

$\begin{array}{llllll}\text { A } & 22 & 0 & 0 & 0 & 0\end{array}$ 
APPENDIX F.--Sample DLG Data File

(Standard Distribution Format)--continued

$\begin{array}{lllllllll}\text { L } & 1 & 74 & 72 & 1 & 5 & 2 & 0 & 0\end{array}$

$\begin{array}{llll}-2259 & 1824 & -2260 & 1855\end{array}$

$\begin{array}{lllllllll}\mathrm{L} & 2 & 8 & 7 & 1 & 5 & 2 & 0 & 0\end{array}$

$-2261 \quad 1263-2260 \quad 1285$

$\begin{array}{lllllllll}\mathrm{L} & 3 & 9 & 5 & 4 & 2 & 13 & 1 & 0\end{array}$

$\begin{array}{llllllllllll}-151 & 1156 & -147 & 1180 & -153 & 1189 & -161 & 1193 & -198 & 1181 & -211 & 1184\end{array}$

$\begin{array}{llllllllllll}-253 & 1174 & -263 & 1181 & -268 & 1192 & -264 & 1238 & -264 & 1333 & -250 & 1361\end{array}$

$-2561394$

$50 \quad 412$

$\begin{array}{lllllllll}\text { L } & 4 & 115 & 8 & 1 & 4 & 2 & 0 & 0\end{array}$

$\begin{array}{llll}-2260 & 1091 & -2261 & 1263\end{array}$

$\begin{array}{lllllllll}\text { L } & 5 & 10 & 10 & 2 & 7 & 10 & 1 & 0\end{array}$

$\begin{array}{llllllllllll}772 & 1079 & 773 & 1109 & 794 & 1161 & 803 & 1169 & 816 & 1169 & 823 & 1162\end{array}$

$\begin{array}{llllllll}824 & 1117 & 814 & 1081 & 810 & 1077 & 772 & 1079\end{array}$

50200

$\begin{array}{lllllllll}\text { L } & 6 & 11 & 6 & 4 & 4 & 21 & 1 & 0\end{array}$

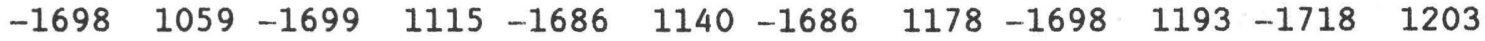

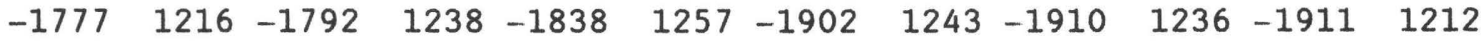

$\begin{array}{llllllllllll}-1920 & 1208 & -1929 & 1214 & -1957 & 1249 & -1957 & 1253 & -1981 & 1281 & -2010 & 1333\end{array}$

$\begin{array}{llllll}-2009 & 1351 & -2014 & 1361 & -2034 & 1365\end{array}$

$50 \quad 412$

$\begin{array}{lllllllll}\text { L } & 7 & 15 & 11 & 4 & 4 & 17 & 1 & 0\end{array}$

$\begin{array}{llllllllllll}-1292 & 929 & -1295 & 951 & -1306 & 973 & -1308 & 987 & -1321 & 1000 & -1359 & 1019\end{array}$

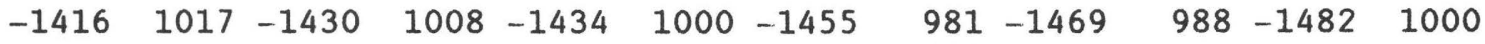

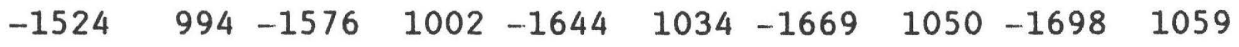

$50 \quad 412$

$\begin{array}{lllllllll}\mathrm{L} & 8 & 16 & 115 & 4 & 4 & 11 & 2 & 0\end{array}$

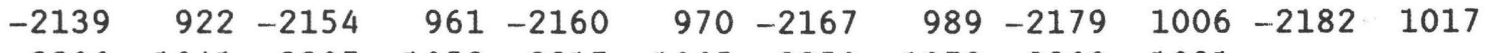

$\begin{array}{llllllllll}-2206 & 1041 & -2207 & 1052 & -2217 & 1065 & -2250 & 1079 & -2260 & 1091\end{array}$

$50 \quad 412 \quad 50 \quad 610$ 
APPENDIX F.--Sample DLG Data File

(Standard Distribution Format)--continued

$\begin{array}{lllllllll}\mathrm{L} & 9 & 84 & 9 & 2 & 2 & 29 & 1 & 0\end{array}$

$\begin{array}{llllllllllll}444 & 923 & 413 & 928 & 370 & 922 & 360 & 904 & 321 & 886 & 267 & 921\end{array}$

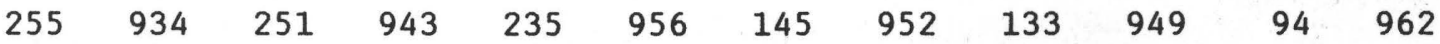

$\begin{array}{llllllllllll}71 & 955 & 44 & 957 & 12 & 981 & -26 & 988 & -37 & 997 & -54 & 1027\end{array}$

$\begin{array}{llllllllllll}-74 & 1048 & -80 & 1060 & -87 & 1086 & -85 & 1115 & -94 & 1124 & -96 & 1165\end{array}$

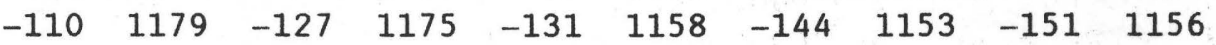

$50 \quad 412$

$\begin{array}{lllllllll}\mathrm{L} & 10 & 17 & 17 & 9 & 2 & 12 & 1 & 0\end{array}$

$\begin{array}{llllllllllll}489 & 919 & 489 & 908 & 498 & 900 & 510 & 900 & 524 & 906 & 570 & 902\end{array}$

$\begin{array}{llllllllllll}578 & 910 & 578 & 927 & 529 & 933 & 498 & 932 & 492 & 927 & 489 & 919\end{array}$

$\begin{array}{lllllllll}\mathrm{L} & 11 & 17 & 84 & 2 & 2 & 3 & 2 & 0\end{array}$

$\begin{array}{llllll}489 & 919 & 465 & 924 & 444 & 923\end{array}$

$50 \quad 412 \quad 50 \quad 610$

$\begin{array}{lllllllll}\text { L } & 12 & 87 & 84 & 2 & 2 & 3 & 1 & 0\end{array}$

$\begin{array}{llllll}511 & 836 & 472 & 873 & 444 & 923\end{array}$

$50 \quad 412$

$\begin{array}{lllllllll}\mathrm{L} & 13 & 89 & 87 & 2 & 2 & 3 & 1 & 0\end{array}$

$\begin{array}{llllll}527 & 788 & 511 & 816 & 511 & 836\end{array}$

$50 \quad 412$

$\begin{array}{lllllllll}\text { L } & 14 & 21 & 20 & 2 & 1 & 2 & 0 & 0\end{array}$ $\begin{array}{llll}2262 & 172 & 2261 & 200\end{array}$

$\begin{array}{lllllllll}\text { L } & 24 & 49 & 50 & 15 & 1 & 2 & 0 & 0\end{array}$

$\begin{array}{llll}-1188 & 2729 & -1249 & 2729\end{array}$

$\begin{array}{lllllllll}\text { L } & 25 & 51 & 49 & 14 & 1 & 2 & 0 & 0\end{array}$

$\begin{array}{llll}-1146 & 2729 & -1188 & 2729\end{array}$ 
APPENDIX G.--Sample DLG Data File

(Optional Distribution Format)

CARTERSVILLE, GA 01

1981,

100000. S01

RO4 . RDSO1
$\begin{array}{lll}3 & 1 & 16\end{array}$
$0.25400000000 D+01 \quad 4$
$\begin{array}{lll}0 & 4 & 1\end{array}$
$-0.840560150000038 D+08$
$0.340260150000010 D+08$
$0.000000000000000 D+00$
$0.000000000000000 D+00$
$0.000000000000000 \mathrm{D}+00$
$0.000000000000000 D+00$
$0.000000000000000 D+00$
$0.000000000000000 \mathrm{D}+00$
$0.000000000000000 D+00$
$0.000000000000000 D+00$
$0.000000000000000 D+00$
$0.000000000000000 D+00$
$0.000000000000000 \mathrm{D}+00$
$0.000000000000000 D+00$
$0.000000000000000 D+00$

$0.10000000000 \mathrm{D}+01 \quad 0.00000000000 \mathrm{D}+00 \quad 0.00000000000 \mathrm{D}+00 \quad 0.00000000000 \mathrm{D}+00$

\begin{tabular}{|c|c|c|c|c|}
\hline SV & & 34.375000 & -85.000000 & 68 \\
\hline NI & & 34.500000 & -85.000000 & \\
\hline $\mathbf{N}$ & & 34.500000 & -84.875000 & \\
\hline St & & 34.375000 & -84.875000 & \\
\hline & $\mathrm{S}$ & TRAILS & 551 & 551010 \\
\hline $\mathbf{N}$ & 1 & 695392.26 & 3805588.76 & \\
\hline & 24 & 725 & & \\
\hline $\mathbf{N}$ & 2 & 685742.29 & 3819258.76 & \\
\hline & 1 & -87 & & \\
\hline $\mathbf{N}$ & 3 & 684845.86 & 3819240.53 & \\
\hline & -1 & $-23-258$ & & \\
\hline $\mathbf{N}$ & 4 & 687098.38 & 3819286.33 & \\
\hline & 2 & -34 & & \\
\hline $\mathbf{N}$ & 5 & 687347.30 & 3819288.85 & \\
\hline & 3 & -35 & & \\
\hline $\mathbf{N}$ & 6 & 687509.77 & 3819294.70 & \\
\hline & 4 & -42 & & \\
\hline $\mathbf{N}$ & 7 & 687735.78 & 3819299.29 & \\
\hline & 5 & $\begin{array}{ll}-6 & -43\end{array}$ & & \\
\hline $\mathbf{N}$ & 8 & 687842.44 & 3819301.46 & \\
\hline & 6 & $\begin{array}{ll}-7 & -45\end{array}$ & & \\
\hline N & 9 & 687969.42 & 3819304.04 & \\
\hline & 7 & -67 & & \\
\hline $\mathbf{N}$ & 10 & 688042.96 & 3819310.62 & \\
\hline & 8 & $\begin{array}{ll}-9 & -66\end{array}$ & & \\
\hline N & 11 & 688129.40 & 3819307.29 & \\
\hline & 9 & -80 & & \\
\hline N & 12 & 688462.08 & 3819314.06 & \\
\hline & 10 & $\begin{array}{ll}-11 & -31\end{array}$ & & \\
\hline $\mathbf{N}$ & 13 & 688632.22 & 3819317.52 & \\
\hline & 11 & $\begin{array}{ll}-12 & -32\end{array}$ & & \\
\hline N & 14 & 688837.92 & 3819321.70 & \\
\hline & 12 & $\begin{array}{ll}-13 & -24\end{array}$ & & \\
\hline $\mathbf{N}$ & 15 & 688947.12 & 3819323.92 & \\
\hline & 13 & $-14 \quad-26$ & & \\
\hline $\mathbf{N}$ & 16 & 689490.57 & 3819334.97 & \\
\hline & 14 & $-15 \quad-154$ & & \\
\hline
\end{tabular}

$683898.58 \quad 3805355.05$

$683624.37 \quad 3819215.69$

$695100.28 \quad 3819449.04$

$695392.26 \quad 3805588.76$

ROADS AND TRAILS $0 \quad 551$

$\begin{array}{lccllll}198 & 198 & 011 & 747 & 747 & 1 \\ 2 & & 0 & 0 & & \end{array}$

$3 \quad 0$

$3 \quad 0 \quad 0$

300

$3 \quad 0 \quad 0$

$3 \quad 0 \quad 0$

$3 \quad 0 \quad 0$

$3 \quad 0 \quad 0$

$3 \quad 0 \quad 0$

300

300

$3 \quad 0 \quad 0$

300

$3 \quad 0 \quad 0$

300

300 
APPENDIX G.--Sample DLG Data File

(Optional Distribution Format)--continued

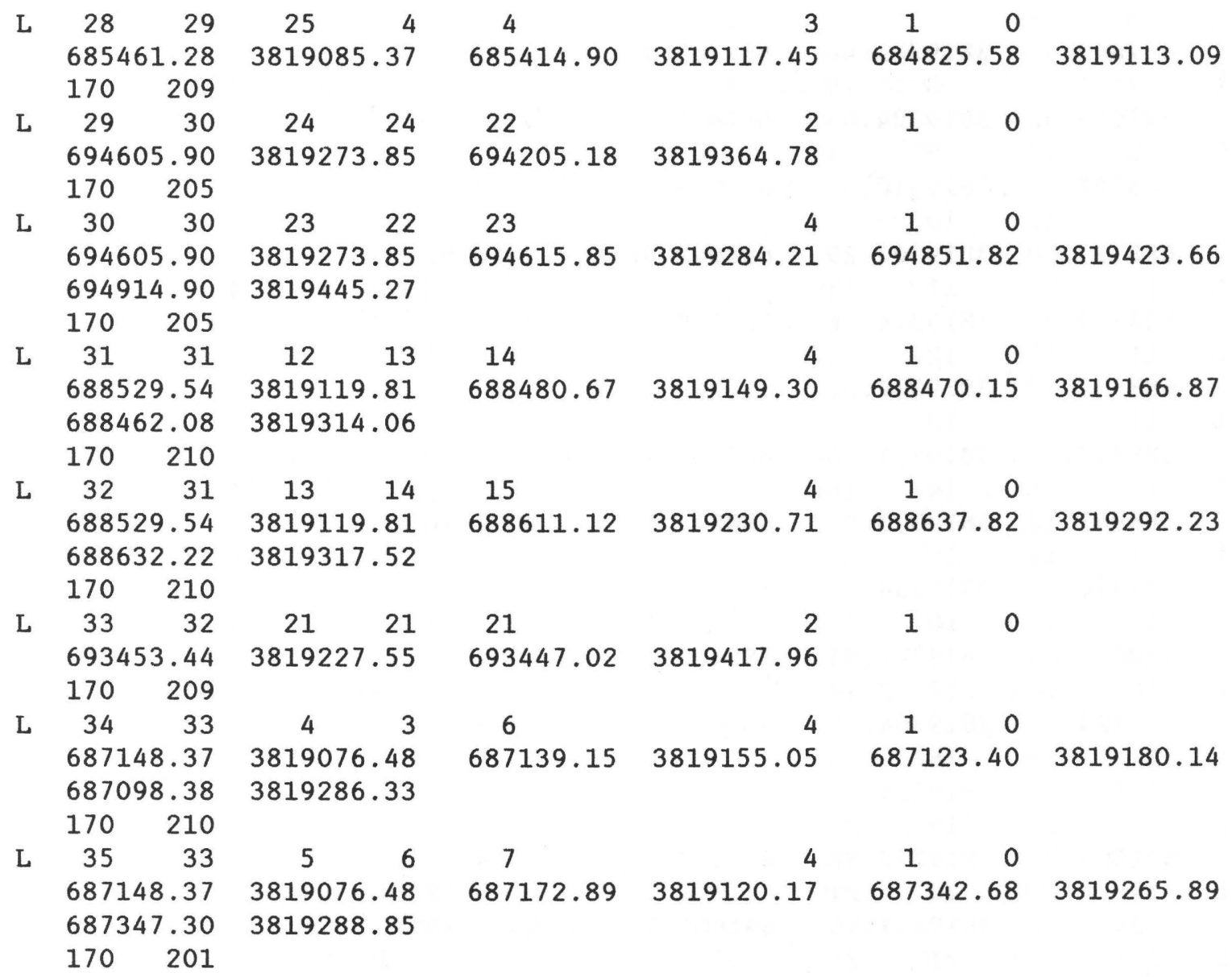

